\title{
Antibiotic resistance in the community
}

Citation for published version (APA):

Bruinsma, N. (2002). Antibiotic resistance in the community. [Doctoral Thesis, Maastricht University]. Universiteit Maastricht. https://doi.org/10.26481/dis.20021212nb

Document status and date:

Published: 01/01/2002

DOI:

10.26481/dis.20021212nb

Document Version:

Publisher's PDF, also known as Version of record

\section{Please check the document version of this publication:}

- A submitted manuscript is the version of the article upon submission and before peer-review. There can be important differences between the submitted version and the official published version of record.

People interested in the research are advised to contact the author for the final version of the publication, or visit the DOI to the publisher's website.

- The final author version and the galley proof are versions of the publication after peer review.

- The final published version features the final layout of the paper including the volume, issue and page numbers.

Link to publication

\footnotetext{
General rights rights.

- You may freely distribute the URL identifying the publication in the public portal. please follow below link for the End User Agreement:

www.umlib.nl/taverne-license

Take down policy

If you believe that this document breaches copyright please contact us at:

repository@maastrichtuniversity.nl

providing details and we will investigate your claim.
}

Copyright and moral rights for the publications made accessible in the public portal are retained by the authors and/or other copyright owners and it is a condition of accessing publications that users recognise and abide by the legal requirements associated with these

- Users may download and print one copy of any publication from the public portal for the purpose of private study or research.

- You may not further distribute the material or use it for any profit-making activity or commercial gain

If the publication is distributed under the terms of Article $25 \mathrm{fa}$ of the Dutch Copyright Act, indicated by the "Taverne" license above, 


\title{
Antibiotic Resistance in the Community
}

\author{
Antibiotica Resistentie in de Samenleving
}

\section{PROEFSCHRIFT}

Ter verkrijging van de graad van doctor aan de Universiteit Maastricht, op gezag van de Rector Magnificus, Prof. dr. A.C. Nieuwenhuijzen Kruseman, volgens het besluit van het College van Decanen, in het openbaar te verdedigen op donderdag 12 december 2002 om 14.00 uur.

$$
\text { door }
$$

Nienke Bruinsma 
Promotor

Prof. dr. C.A. Bruggeman

\section{Co-promotores}

Dr. E.E. Stobberingh

Dr. A.E.J.M. van den Bogaard

\section{Beoordelingscommissie}

Prof. dr. P.G. Knipschild (voorzitter)

Prof. dr. J.E. Degener (Rijksuniversiteit Groningen)

Prof. dr. J.F.M. Smits

Dr. R.J.L.Willems (RIVM)

Prof. dr. J van der Zee

ISBN: 90-9016398-0

Druk: Febodruk b.v.

Kaft: Auke Ferwerda

De studies gepresenteerd in dit proefschrift werden gefinancierd met behulp van grant 97-1104 van ZorgOnderzoek Nederland (ZON). 
CHAPTER 1 General Introduction and Outline of the Thesis 5

CHAPTER 2 Antibiotic use and the prevalence of antibiotic 29

resistance of healthy volunteers in the Dutch community

CHAPTER 3 Antibiotic use and resistance in different regions of the Dutch community

CHAPTER 4 The influence of population density on antibiotic resistance $\mathbf{6 3}$

CHAPTER 5 Hospitalisation, a risk factor for antibiotic resistance in the community?

CHAPTER 6 Difference in genetic homogeneity of vancomycin resistant and susceptible Enterococcus faecium isolated from different human and animal sources analysed by amplified fragment length polymorphism 


\section{CHAPTER 1}

General Introduction and Outline of the Thesis 


\section{INTRODUCTION}

Since antibiotics became clinically available in the 1940 s, they have been used as safe magic bullets to treat bacterial infections without risk for the treated patients ${ }^{41}$. Already at the start of antibiotic therapy, bacteria with acquired resistance against antibiotics were isolated, though very rarely. In the passing decades however, susceptible bacteria have been eliminated by the increasing amounts of antibiotics they have been exposed to and only unsusceptible species and strains with resistance mechanisms to ward of destruction were able to survive and replaced the original susceptible population. The rise of antibiotic resistance in bacteria has become a world-wide and increasing public health problem, as infections caused by resistant bacteria are often resistant to more than one antibiotic, and are therefore difficult to treat and to control ${ }^{41}$. Indeed in some countries the unacceptable situation has been reached that the majority of hospital isolates of Gram-negative enteric bacteria, staphylococci and enterococci have become resistant to most, formerly effective, antibiotics. In Table 1 an overview of the emergence of resistance after the discovery and introduction of an antibiotic agent is displayed. Until recently, new antibiotics have always appeared just in the nick of time, before resistance problems got out of hand. However, now the increasingly rapid pace at which bacteria develop and acquire new drug resistance profiles, seem to outpace the rate at which the pharmaceutical industry is able to develop and market new antibiotics ${ }^{73}$.

\section{EMERGENCE OF ANTIBIOTIC RESISTANCE}

\section{Development of antibiotic resistance}

Bacteria can be unsusceptible or intrinsically resistant, which means that a whole species or genus is not susceptible to a certain antibiotic. Acquired resistance is the phenomenon that certain bacteria belonging to a susceptible species are not inhibited or killed any more by concentrations of an antibiotic that would normally do so. There are two ways to acquire resistance, by chromosomal mutation or by acquisition of exogenous genes. The potential for antibiotic resistance by chromosomal mutation is 
intrinsic to all bacteria, because it occurs spontaneously in replicating bacteria due to the imperfect fidelity of DNA replication, and is therefore not influenced by the presence of antibiotics. Indeed, even before antibiotics became clinically available resistant bacteria could be found in soil, intestinal flora and clinical isolates, but only in very small numbers ${ }^{9,26}$. Resistance by gene acquisition generally refers to the prior existence of a resistance gene that is then acquired by another bacterium ${ }^{24}$ through transformation, conjugation, or transduction. Resistance genes can be found on the bacterial chromosome, or are carried on plasmids, that by conjugation can transfer itself to other bacteria, even of different species. The resistance genes are found on plasmids which are embedded in small DNA units called transposons, that easily hop within one bacteria between its chromosome and plasmids present and even from bacteria to bacteria.

TABLE 1. The emergence of resistance after the introduction of an antibiotic agent.

\begin{tabular}{llll} 
Antibiotic & Discovered & Clinically available & Observed resistance \\
\hline Penicillin & 1940 & 1943 & 1940 \\
\multicolumn{1}{c}{ Methicillin } & & 1961 & 1965 \\
Streptomycin & 1944 & 1947 & 1947,1956 \\
Tetracycline & 1948 & 1952 & 1956 \\
Erythromycin & 1952 & 1955 & 1956 \\
Vancomycin & 1956 & 1972 & 1987 \\
Nalidixic acid & 1960 & 1962 & 1966 \\
Gentamicin & 1963 & 1967 & 1970 \\
Third-generation & & & 1985 \\
Cephalosporins & 1956 & 1980 & 1985 \\
Fluoroquinonlones & 1978 & 1982 & Adapted fom EME I999
\end{tabular}

Adapted from EMEA 1999

\section{Resistance mechanisms}

Resistance genes give rise to antibiotic degrading or chemically modifying enzymes inactivating the drug, or enzymes that can eliminate the drug's target, entry ports, or can manufacture pumps that export antibiotics. In Table 2 various resistance 
mechanisms and the way they can be acquired are presented with examples of the affected antibiotics.

TABLE 2. Biochemical mechanisms of antibiotic resistance and their genetic determinants.

\begin{tabular}{|c|c|c|c|}
\hline \multirow[b]{2}{*}{ Mechanisms } & \multirow[b]{2}{*}{ Examples } & \multicolumn{2}{|c|}{ Genetic determinants } \\
\hline & & Mutation & Gene acquisition \\
\hline Reduced permeability & Aminoglycosides & + & + \\
\hline \multirow[t]{2}{*}{ Active efflux } & Tetracycline & & + \\
\hline & Fluoroquinolones & + & \\
\hline \multirow[t]{4}{*}{ Alteration of drug target } & Erythromycin & & + \\
\hline & Fluoroquinolones & + & \\
\hline & Rifampin & + & \\
\hline & Tetracycline & & + \\
\hline \multirow[t]{2}{*}{ 'By-pass' inhibited step } & Sulfonamides & & + \\
\hline & Trimethoprim & & + \\
\hline \multirow[t]{3}{*}{ Inactivation of drug } & Aminoglycosides & & + \\
\hline & Chloramphenicol & & + \\
\hline & B-lactams & + & + \\
\hline \multirow[t]{2}{*}{ Amplification of target } & Trimethoprim & + & \\
\hline & Sulfonamides & + & \\
\hline Sequestration of drug & B-lactams & + & + \\
\hline
\end{tabular}

Adapted from Davies $1997^{10}$

\section{Selection pressure of antibiotics}

Due to mutations or acquisition of resistance genes, a minority of bacteria resistant to a certain antibiotic may be present in a population. Whether these resistant strains will survive and replicate depends in large degree on the selection pressure being present. If due to the increasing use of antibiotics the susceptible bacteria are eliminated, their resistant kin will replace them and the majority of the population will become resistant. If the selection pressure is removed the resistant bacteria may be replaced again by susceptible bacteria for two reasons: introduction of new susceptible bacteria from the environment and because resistant bacteria are less "fit". This means that they often have longer generation times and are less adaptable than their susceptible 
relatives. Hence in the absence of continuing selection of antibiotics in the community, the key factor driving a decrease in antibiotic resistance may be the 'fitness cost' of resistance i.e. resistance will decline after a reduction in antibiotic use if resistant organisms are at a disadvantage for transmission or persistence ${ }^{2,39}$. In contrast, in hospitals a change in resistance levels will be primarily driven by the admission of new patients which often bring with them drug-susceptible flora, which may 'dilute' levels of resistance in the absence of continuing selection of antibiotics ${ }^{42}$.

\section{Dissemination of antibiotic resistance}

Next to selection pressure of antibiotic use, the dissemination of resistant bacteria and resistance genes is a very important factor for antibiotic resistance to spread. Dissemination of genetic bacteria through direct or indirect contact with other individuals may lead to colonisation by drug-resistant bacteria or transfer of resistance genes to the endogenous flora from one individual to another.

The excessive use of antibiotics by mankind has led to the excretion of large numbers of antibiotic resistant bacteria into the environment enhancing the chance of colonisation and infection to spread among individuals ${ }^{73}$. Especially in places where the density of hosts (humans or animals) and antibiotic usage is high and breaches in hygienic barriers are likely to occur (hospitals, day care centers, nursing homes and animal farms), antibiotic resistant bacteria and resistant genes can easily disseminate from one host to another.

\section{Antibiotic resistance in the commensal flora}

Administration of an antimicrobial agent may not only kill the pathogen but will also change the composition of the commensal flora. Even though pathogenic bacteria cause problems in treating a patient when resistant, and form a tangible threat for public health, commensal bacteria are just a well exposed to selection and dissemination. Benign commensal bacteria that lack the relevant resistance will die, and those that are intrinsic non-susceptible or by chance, have acquired the relevant resistant gene will proliferate and expand into the niche abandoned by the exterminated susceptible bacteria ${ }^{66}$. 
The high numbers of bacteria and the many species present make the intestinal tract of man and animals an ideal setting for gene exchange. An entering pathogen and a passing trough non-pathogenic bacterium might obtain resistance genes from the commensal flora even without colonising ${ }^{66}$. Therefore the commensal flora is a very important and underestimated reservoir of resistant bacteria and genes for pathogenic bacteria.

\section{SURVEILLANCE OF ANTIBIOTIC USE AND RESISTANCE}

The main objectives of antimicrobial resistance surveillance programs are to provide baseline data describing the prevalence of resistance within populations and assessment how this responds over time to changes in selective pressure from antibiotic use. Also changes due to interaction with other populations as a result of exchange of resistant bacteria or resistance genes between populations and the effects of interventions are assessed. This is called resistance epidemiology.

Next to the surveillance of resistance prevalence in clinical isolates, an alternative and fast increasing approach is surveillance based on the prevalence of resistance in the endogenous flora of populations. It is widely considered that most infections in a population result from the commensal flora carried within a population. Moreover resistant bacteria of the endogenous flora not only constitute an enormous reservoir of resistance genes for (potentially) pathogenic bacteria, but also the level of resistance in the endogenous flora is considered to be a good indicator for the selection pressure exerted by antibiotic use on a population and for resistance problems to be expected in pathogens.

The use of indicator bacteria of the endogenous flora, like Escherichia coli and enterococci in faecal samples of randomly selected individuals of a population makes it not only feasible to measure the selective pressure of antibiotic use in that population, but also to compare the prevalence of resistance in different populations and to detect transfer of resistance from one population to another. E. coli and enterococi belong to the endogenous flora of humans and most animal species, making comparison between populations of both sources possible. 


\section{RESERVOIRS OF RESISTANCE}

\section{Care centres}

The extent of antibiotic resistance in a population is strongly correlated with the level of antibiotic usage and the ease with which bacteria can disseminate: crowding and poor sanitary levels ${ }^{73}$. Hospitals are traditionally the major breeding grounds of resistant bacteria ${ }^{20}$. The large amounts of antibiotics patients are exposed to in hospitals ${ }^{19}$ and the relatively high patient density and frequent contact with healthcare workers, who can act as suitable vectors, ${ }^{65}$ makes the hospital environment a place for resistance to be easily spread ${ }^{40,46}$. In addition, underlying illnesses and therapeutic interventions that may cause immunosuppression make a hospitalised patient more prone to colonisation and infection by (resistant) bacteria ${ }^{22,65}$. Comparable situations of susceptible hosts crowded together with inevitable breaches in hygiene are found in day care centres and nursing homes ${ }^{48}$, facilitating the dissemination of antibiotic resistant bacteria and resistance genes.

\section{Community}

Antibiotic use. Even though the antibiotic use in hospitals and nursing homes is high, by far most antibiotics (approximately $80 \%$ ) are consumed by humans in the open population ${ }^{63}$. This extensive use of antibiotics is another reason why the commensal flora of healthy individuals is such an important reservoir of resistant bacteria. Large differences in the amount and types of antibiotics consumed in the community are observed between countries. Reasons for this are among other factors differences in prescribing habits, antibiotic policies and socio-economic and cultural aspects ${ }^{7,34,38}$, Not surprisingly, also large differences in the prevalence of antibiotic resistance are observed between countries. Also within one country antibiotic consumption and consequently prevalence of antibiotic resistance can vary considerably $25,27,68$, which emphasizes the generally accepted relation between antibiotic use and prevalence of resistance. In addition various studies have described the effectiveness of altering antibiotic prescribing policies on antibiotic resistance ${ }^{12,16,21,58}$. 
Dissemination. Acquisition of drug-resistant bacteria through contact with other individuals has not been as extensively investigated in the community as it has been in hospitals, but there is certainly evidence showing this to occur in the home situation ${ }^{13}$, $17,47,55$ as well as in other community environments, such as day care centres ${ }^{53}$. A higher prevalence of resistance has also been observed among persons living in close contact with pigs and poultry. Several studies showed that pig and poultry farmers have a much higher prevalence and degree of resistance in their intestinal flora compared to urban residents living in the same geographic region. Moreover E. coli and enterococci with identical genotypes were isolated from animals and farmers which strongly suggests clonal transmission ${ }^{64}$. Poultry and pork were also suggested as a possible source of quinolone resistant Escherichia coli in the community in Barcelona, where $26 \%$ of children were found to be faecal carriers of these organisms despite apparently never having been exposed to quinolones ${ }^{18}$. This clearly shows that living in an environment with resistant bacteria is a real risk for acquiring such bacteria and that the closer the contact the larger the risk. Similar to living in close contact with animals one could speculate that living in close contact with other persons harbouring resistant micro-organisms or resistant genes is a risk factor to acquire antibiotic resistance in the community.

\section{Animal husbandry}

Next to the antibiotic use in human medicine (in the Netherlands approximately $80.000 \mathrm{kgs}$ active ingredient at $100 \%$ purity per year) a large part of antibiotics is used in animal husbandry for therapy $(300.000 \mathrm{kgs})$ and for mere economic reasons to increase growth of animals as so called antimicrobial growth promoters (approximately $250.000 \mathrm{kgs})^{72}$. This has resulted in a large reservoir of resistant bacteria and genes in the intestinal tract of farm animals. Despite high standards of hygiene during the slaughtering process, contamination of meat and meat products by the intestinal flora of slaughtered animals cannot be completely avoided. Hence faecal (resistant) bacteria of food animals can reach humans through the food chain ${ }^{74,81}$. Genetically identical bacteria have been found in food animals, meat products ${ }^{33}$, farmers ${ }^{70,} 71,74$ outpatients, and hospitalised patients suggesting that transmission 
between animals and humans can occur and may contribute to colonisation and subsequently infection in humans ${ }^{64,69}$.

\section{Interaction of reservoirs in the community}

The dissemination of antibiotic resistant bacteria and resistance genes between hosts is not only confined to a specific reservoir. Bacteria and consequently resistance know no borders, and do not stop at a hospital door, or an animal farm. For example, when patients are discharged, hospital acquired resistance is taken home and might contribute to the dissemination of resistance genes and resistant bacteria in the community. In addition, resistant bacteria or resistance genes can also be introduced in a population from far away countries by tourists and visitors, like animal bacteria that can reach the community via foods of animal origin.

The interaction of all these resistance reservoirs takes mainly place in the community and in addition, most human antibiotic use is in the community. Also resistant bacteria and their resistance gene found in the hospital have been once introduced from the community into the hospital. Therefore the prevalence and degree of antibiotic resistance in the community occupies a key position in resistance epidemiology and is to be considered as a very important source to monitor. It represents the prevalence of antibiotic resistance in general, and consequently provides a basis for antibiotic prescribing and infection control policies. In addition, it also represents resistance problems that might be encountered in hospitals as inevitably, healthy individuals living in the community will at some point have to attend a general practitioner or will be admitted to a hospital.

\section{ANTIBIOTIC RESISTANCE IN FAECAL ESCHERICHIA COLI}

A limited number of studies have been performed determining the prevalence of resistant faecal $E$. coli in healthy volunteers and hospitalised patients. In general, high prevalences of resistant faecal E. coli against amoxicillin, oxytetracycline and trimethoprim have been isolated from healthy volunteers in various European 
countries ${ }^{4,18,36,43,44,51,78}$, the USA ${ }^{38}$, South America ${ }^{6,68}$ and developing countries ${ }^{1 \text {. }}$ $59,60,38$, varying between $12 \%-89 \%, 14 \%-68 \%$, and $9 \%-45 \%$ respectively. In addition, several studies have shown that children and the elderly are populations with a higher risk for colonization of their commensal flora by resistant and even multidrug resistant E.coli ${ }^{6,38,78}$ due to the high risk environment for acquisition of resistant bacteria and resistance genes provided by day-care centres and nursing homes respectively. Not surprisingly, the hospital environment has also been shown to effect the commensal flora of patients. ${ }^{37,51}$

\section{ANTIBIOTIC RESISTANCE IN FAECAL ENTEROCOCCI}

Most research on the resistance prevalence of faecal enterococci has been focused on the prevalence of vancomycin resistance in healthy volunteers and hospitalised patients. In EU countries vancomycin resistant enterococci (VRE) are relatively frequently found in 'healthy' individuals in the community and in farm animals, whereas VRE still seem to be very uncommon in hospitals ${ }^{15,31,50,62,75}$.

The considerable pool of transmissible vanA-mediated glycopeptide resistance in the EU community is most likely caused by the abundant use of avoparcin (a glycopeptide like vancomcyin) in the recent past for growth promotion in animals ${ }^{67}$. 69. In April 1997, the European Commission suspended the use of avoparcin in animals. Denmark had already forbidden its use in 1995 and Germany in 1996. Within 2 years of stopping the use of avoparcin in The Netherlands, not only the number of VRE in the faecal flora of food animals but also of healthy humans significantly decreased ${ }^{69}$. Similarly, a decrease in the number of VRE in poultry (meats) was found in Denmark, Germany and Italy after the ban of avoparcin ${ }^{3,32,52}$, whereas in Norwegian poultry the number of VRE has remained high three years after the ban ${ }^{5,35}$. In Germany the number of VRE in faecal samples of healthy humans also decreased from 12\% (1994) to $3 \%(1997)$, and in Belgium the percentage of VRE carriers in hospitals decreased from $12 \%$ in 1996 to less than $1 \%$ in $2001^{28}$.

In contrast with the EU, alarming situations of infections due to VRE are found in USA hospitals, whereas a community reservoir is absent ${ }^{8}$. Vancomycin resistance in 
these hospital isolates is as commonly of the $\operatorname{VanB}$ as of the VanA-type. As avoparcin does not select for $V a n B$-resistance in enterococci this paradox is probably caused by the high use of vancomycin in the US hospitals. A comparison of the US with Europe, showed that yearly usage of vancomycin, both injectable and oral forms, was five to tenfold higher in the USA ${ }^{30}$.

The existence in the EU of a large pool (reservoir) of enterococci with transposons carrying the vanA gene cluster might endanger public health. Next to the fact that infections by VRE are difficult to treat, it might also hold a risk for transfer of the VanA gene cluster to staphylococci. This has been shown to be possible in vitro and in experimental animals, and has recently unfortunately also happened in a hospital patient in the USA. ${ }^{49.61}$

\section{Molecular techniques for genotyping of VRE}

The ability to identify accurately the strains of infectious agents that cause disease is central to epidemiological surveillance and public health decisions. Molecular typing methods are used to address two very different kinds of problem. First to trace the transmission and dissemination of strains in intra- and inter-hospital outbreaks and second in resistance epidemiology to determine the genetic relatedness between isolates of which the relatedness is not directly clear. Because of the high degree of strain differentiation, pulsed-field gel electrophoresis (PFGE) is able to identify the microvariation that is needed to distinguish between strains circulating within a geographic area and has therefore been considered the reference standard for studying individual outbreaks in a hospital. However PFGE is too discriminatory to establish the degree of genetic relatedness between epidemiological nonrelated strains, because the banding patterns of such strains are often completely different. Therefore, using PFGE is a too insensitive method to allow disclosure of strain-characteristic differences in the host specificity of enterococci, as it fails to see the forest for the trees $^{45,79}$.

Amplified-fragment length polymorphism analysis (AFLP) allows for the analysis of polymorphism among small restriction fragments and is based on selective amplification of restriction fragments generated from total genomic DNA ${ }^{14}$. The 
advantage of AFLP typing is that these small restriction fragments originate from both variable and conserved DNA sequences, thus establishing a degree of genetic relatedness that, by PFGE, would show no similarity at all.

Various developed molecular techniques like PFGE, RFLP (PCR-restriction fragment length polymorphism), ribotyping, and random amplified polymorphic DNA analysis often lack adequate discriminatory power, and the reproducibility is poor. Whereas AFLP can be easily automated, which allows standardization and high throughput of strains in epidemiological investigations. Moreover, digitisation of the data results in easy storage, cross-referencing, and exchange of data between laboratories ${ }^{14}$. However, AFLP data may be less suitable for global epidemiology, as variations in band intensities can easily occur between laboratory causing a source of ambiguities when curve based similarity coefficients like the Pearson correlation are used to compare banding patterns ${ }^{56}$. For studying the global epidemiology, recognition and tracking world-wide, the most appropriate technique is multilocus sequence typing (MLST), as MLST is based on identifying alleles from DNA sequences of internal fragments of housekeeping genes, and is pre-eminently useful for electronic data ${ }^{23}$.

\section{Host specificity in VRE}

Molecular typing has revealed genetically related VRE isolates in food animals, meat products ${ }^{33}$, outpatients, and hospitalised patients suggesting that transmission between animals and humans can occur and may contribute to colonisation and subsequently infection in humans ${ }^{54,64,74}$. Molecular comparison by pulsed-field gel electrophoresis (PFGE) ${ }^{11,64,74,76}$, and amplified-fragment length polymorphism (AFLP) analysis ${ }^{77,79}$ of human- and animal-derived Enterococcus faecium revealed the existence of a common human and pig genogroup, while poultry derived VREF clustered in a separate genogroup. However, identical genotypes of several enterococcus species by PFGE have been isolated from poultry and poultry farmers, but especially typing of the $\mathrm{Tn} / 546$ transposon $11,29,57,70,80,82$ showed that identical $\mathrm{Tn} / 546$ derivatives were found in humans and poultry suggesting horizontal spread of the van $A$ transposon from poultry to human. 


\section{CONCLUSIONS}

The emergence of antibiotic resistant bacteria driven by the interplay of many mechanistic and epidemiological factors is very complex. Mechanistically, resistance by target alteration, reduced permeability, and drug inactivation can occur by both chromosomal mutation and acquisition of new genetic elements. Epidemiologically, exposure to antimicrobial agents provides a growth and persistence advantage for any existing resistant bacteria, generally irrespective of the mechanism ${ }^{24}$.

Sixty years of lavish usage of antibiotics in human and veterinary medicine and in agriculture has progressively eroded the clinical efficiency of antibiotics because of a rising tide of acquired resistance in pathogenic bacteria. In addition resistance observed in pathogenic bacteria is only the top of the resistance iceberg and an enormous reservoir of resistance genes has accumulated in the intestinal flora of man and other animals.

Despite that emergence of resistance is an inevitable sequel of antibiotic use, there is fortunately a growing national and international concern about the increasing resistance and the need for more concerted action to prevent, delay and control bacterial resistance against antibiotics is generally recognised. As interventions should be based on scientifically based decisions, resistance epidemiology should be considered the cornerstone in the control of antibiotic resistance. 


\section{AIMS OF THE STUDY}

The faecal flora of healthy humans in the community serves as a very important reservoir of antibiotic resistant bacteria and resistant genes and its key position in antibiotic resistance epidemiology is generally underestimated. Therefore this thesis focuses on the prevalence and risk factors for selection and dissemination of antibiotic resistance among different populations in the community, to provide epidemiological data for antibiotic policies and if necessary timely interventions.

An ongoing surveillance study determining the prevalence of antibiotic resistance in the faecal flora of healthy volunteers in the community was analysed for the period 1992 till 1999 and was related to the use of antibiotics in the Dutch community. Changes in resistance of the normal commensal flora over time can be considered as an early warning system for resistance to be expected in potentially pathogenic bacteria. In addition a study was performed to determine the differences of antibiotic use among different regions in the Netherlands in relation to the prevalence of antibiotic resistance found. Even within countries differences in the amount of antibiotics prescribed by general practitioners occur, and consequently may affect the prevalence of antibiotic resistance between regions.

Besides antibiotic use, the ability of antibiotic resistance to spread is very important in the development of resistance. If people are living closely together or hygienic barriers are loose the transmission of resistance bacteria and resistant genes between hosts is facilitated. Therefore a study was conducted to measure the effect of population density (as a measure of crowding) in combination with antibiotic use on the prevalence of antibiotic resistance.

Antibiotic resistance reservoirs like the hospital environment and animal husbandry all interact in the community. To assess the effect of antibiotic resistance taken home to the community by hospital patients, a study was performed analysing the prevalence of antibiotic resistance at different points of time before, during and after hospital admission. In addition, the genotypic diversity of bacteria isolated from both human and animal sources was determined to study the transmission between animals and humans, which may lead to colonisation and subsequently infection in humans. 


\section{OUTLINE OF THE THESIS}

This thesis attends to the prevalence, the spread and the risk factors of antibiotic resistance of different populations in the community.

In CHAPTER 2, entitled "Antibiotic use and the prevalence of antibiotic resistance of healthy volunteers in the Dutch community" antibiotic use in 1996 and 1999 was related to the prevalence of antibiotic resistance in the faecal indicator bacteria, $E$. coli and enterococci isolated from healthy volunteers living in the south of the Netherlands. The prevalence of resistance was also compared with resistance data from the same region in 1992.

In CHAPTER 3, entitled "Antibiotic use and resistance in different regions of the Dutch community" the prevalence of antibiotic resistance of Escherichia coli and enterococci isolated from healthy individuals living in three different regions of the Netherlands was determined and the influence of regional antibiotic consumption on the prevalence of resistance was studied.

In CHAPTER 4, entitled "The influence of population density on antibiotic resistance" antibiotic consumption and population density were related to the prevalence of antibiotic resistant faecal $E$. coli and enterococci of healthy volunteers living in three cities from three different countries i.e. Canada, Greece, and the Netherlands and analysed for differences in antibiotic use and population densities.

In CHAPTER 5, entitled "Hospitalisation, a risk factor for antibiotic resistance in the community" the influence of hospitalisation on the prevalence of faecal antibiotic resistant $E$. coli was analysed. The prevalence of antibiotic resistance in faecal $E$. coli on admission, at time of discharge, 1 month and 6 months after discharge of patients admitted to surgical wards of the University hospital Groningen, Maastricht, and Rotterdam was determined. 
In CHAPTER 6, entitled "Difference in genetic homogeneity of vancomycin resistant and susceptible Enterococcus faecium isolated from different human and animal sources analysed by amplified fragment length polymorphism" the genetic relationship among 178 vancomycin resistant Enterococcus faecium (VREF) and vancomycin sensitive Enterococcus faecium (VSEF) strains isolated from faecal samples of humans and pigs in the Netherlands and chickens in Greece and the Netherlands was studied. 


\section{REFERENCES}

I. Amyes, S.G., Tait, S., Thomson, C.J., Payne, D.J., Nandivada, L.S., Jesusdason, M.V., Mukundan, U.D., and Young, H.K. The incidence of antibiotic resistance in aerobic faecal flora in south India. J Antimicrob Chemother 29, 415-25 (1992).

2. Austin, D.J. and Anderson, R.M. Studies of antibiotic resistance within the patient, hospitals and the community using simple mathematical models. Philosoph Transact Royal Society London Series B Biologic Sciences 354, 721-738 (1999).

3. Bager, F., Aarestrup, F.M., Madsen, M., and Wegener, H.C. Glycopeptide resistance in Enterococcus faecium from broilers and pigs following discontinued use of avoparcin. Microb Drug Resist 5, 53-6 (1999)

4. Bonten M, Stobberingh, E., Philips, J., and Houben, A. Antibiotic resistance of escherichia coli in fecal samples of healthy people in two different areas in an industrialized country. infection 20, 258262 (1992).

5. Borgen, K., Simonsen G.S., Sundsfjord, A., Wasteson, Y., Olsvik, O., and Kruse, H.. Continuing high prevalence of VanA-type vancomycin-resistant enterococci on Norwegian poultry farms three years after avoparcin was banned. J Appl Microbiol 89, 478-485 (2000).

6. Calva, J.J., Sifuentesosornio, J., and Ceron, C. Antimicrobial resistance in fecal flora: Longitudinal community-based surveillance of children from urban Mexico. Antimicrobial Agents and Chemotherapy 40, 1699-1702 (1996).

7. Cars, O. Variation in antibiotic use in the European Union. the Lancet 357, 1851-1853 (2001).

8. Coque, T.M., Tomayko, J.F., Ricke, S.C., Okhyusen, P.C., and Murray, B.E. Vancomycin-resistant enterococci from nosocomial, community, and animal sources in the United States. Antimicrob Agents Chemother 40, 2605-9 (1996).

9. Datta, N. and Hughes, V.M. Plasmids of the same Inc groups in Enterobacteria before and after the medical use of antibiotics. Nature 306, 616-7 (1983).

10. Davies, J.E. Origins, acquisition and dissemination of antibiotic resistance determinants. Ciba Found Symp 207, 15-27; discussion 27-35 (1997).

11. Descheemaeker, P.R., Cahpelle, S., Devriese, L.A., Butaye, P., Vandamme, P., and Goossens, H. Comparison of glycopeptide-resistant Enterococcus faecium isolates and glycopeptide resistance genes of human and animal origins. Antimicrob Agents Chemother 43, 2032-2037 (1999).

12. Dominguez, E.A., Smith, T.L., Reed, E., Sanders, C.C., and Sanders, W.E. A pilot study of antibiotic cycling in a hematology-oncology unit. Infect Control Hosp Epidemiol 21, S4-8 (2000). 13. Dominici, P., Bellentani, S., Di Biase, A.R., Saccoccio, G., Le Rose, A., Masutti, F., Viola, L., Balli, F., Tiribelli, C., Grilli, R., Fusillo, M., and Grossi E. Familial clustering of Helicobacter pylori infection: population based study. BMJ 319, 537-40 (1999).

14. Duim, B., Wassenaar, T.M., Rigter, A., and Wagenaar, J. High-resolution genotyping of Campylobacter strains isolated from poultry and humans with amplified fragment length 
polymorphism fingerprinting. Appl Environ Microbiol 65, 2369-75 (1999).

15. Endtz, H.P., van Belkum, A., and van Duin, J. [Vancomycin-resistant enterococci . Work Group Hospital Infection Epidemiology]. Ned Tijdschr Geneeskd 141, 108-9 (1997).

16. Enne, V.I., Livermore, D.M., Stephens, P., and Hall, L.M. Persistance of sulphonamide resistance in Escherichia coli in the UK despite national prescribing restriction. the Lancet 357, 1325-1328 (2001).

17. Gamba, M.A., Martinelli, M., Schaad, H.J., Strueli, R.A., DiPersio, J., Matter, L. et al. Familial transmission of a serious disease--producing group A streptococcus clone: case reports and review. Clin Infect Dis 24, 1118-21 (1997).

18. Garau, J., Xercavins, M., Rodriquez-Carballeira, M., Gomez-Vera, J.R., Coll, I., Vidal, D. et al. Emergence and dissemination of quinolone-resistant Escherichia coli in the community. Antimicrobial Agents and Chemotherapy 43, 2736-2741 (1999).

19. Gaynes, R. and Monnet, D. The contribution of antibiotic use on the frequency of antibiotic resistance in hospitals. Ciba Found Symp 207, 47-56; discussion 56-60 (1997).

20. Gerberding, J.L., McGowan, J.E. Jr, and Tenover, F.C. Emerging nosocomial infections and antimicrobial resistance. Curr Clin Top Infect Dis 19, 83-98 (1999).

21. Gillespie, S.H. Antibiotic resistance in the absence of selective pressure. Int J of Antimicrobial Agents 17, 171-176 (2001)

22. Goldmann, D.A. The epidemiology of antimicrobial resistance. Ecosyst Health 5, 158-163 (1999).

23. Homan, W.L., Tribe, D., Poznanski, S., Li, M., Hogg, G., Spalburg, E. et al. Multilocus sequence typing scheme for Enterococcus faecium. J Clin Microbiol 40, 1963-71 (2002).

24. Hooper, D.C. Minimizing potential resistance: the molecular view--a comment on Courvalin and Trieu-Cuot. Clin Infect Dis 33 Suppl 3, S157-60 (2001).

25. Howard, A.J.M. Factors associated with antibiotic resistance in coliform organisms from community urinary tract infection in Wales. JAC 47, 305-313 (2001).

26. Hughes, D.T. The use of combinations of trimethoprim and sulphonamides in the treatment of chest infections. J Antimicrob Chemother 12, 423-34 (1983).

27. Huovinen, P., Seppala, H., Kataja, J., and Klaukka, T. The relationship between erythromycin consumption and resistance in Finland. Finnish Study Group for Antimicrobial Resistance. Ciba Found Symp 207, 36-41; discussion 41-6 (1997).

28. leven, M, et al. Significant decrease of GRE colonization rate in hospitalised patients after avoparcin ban in animals? Abstracts of the 41 st ICAAC, September and December 2001.

29. Jensen, L.B. Differences in the occurrence of two base pair variants of $\mathrm{Tn} 1546$ from vancomycinresistant enteroeocci from humans, pigs, and poultry. Antimicrob Agents Chemother 42, 2463-2464 (1998).

30. Kirst, H.A., Thompson, D.G., and Nicas, T.I. Historical yearly usage of vancomycin. Antimicrob Agents Chemother 42, 1303-4 (1998). 
31. Kjerulf, A., Pallesen, L., and Westh, H. Vancomycin-resistant enterococci at a large university hospital in Denmark. Apmis 104, 475-479 (1996).

32. Klare, I., Badstubner, D., Konstabel, C., Bohme, G., Claus, H, and Witte, W. Decreased incidence of VanA-type vancomycin-resistant enterococci isolated from poultry meat and from fecal samples of humans in the community after discontinuation of avoparcin usage in animal husbandry. Microb Drug Resist 5, 45-52 (1999).

33. Klare, I., Heier, H., Claus, H., Bohme, G., Marin, S., Seltmann, G. et al. Enterococcus faecium strains with vanA-mediated high-level glycopeptide resistance isolated from animal foodstuffs and fecal samples of humans in the community. Microb Drug Resist 1, 265-72 (1995).

34. Kresken, M., Hafner, D., Mittermayer, H., Verbist, L. Bergogne-Berezin, E., Giamarellou, H. et al. Prevalence of fluoroquinolone resistance in Europe. Infection 22, s90-98 (1994).

35. Kruse H. Johansen, B.K., Rorvik, L.M., and Schaller, G. The use of avoparcin as a growth promoter and the occurence of vancomycin-resistant enterococcus species in Nowegian Poultry and swine production. Microbial drug resistance 5, 135-139 (1999).

36. Leistevuo, T., Leistevuo, J., Osterblad, M., Arvola, T., Toivonen, P., Klaukka, T. et al. Antimicrobial resistance of fecal aerobic gram-negative bacilli in different age groups in a community. Antimicrob Agents Chemother 40, 1931-4 (1996).

37. Leistevuo, T., Osterblad, M., Toivonen, P., Kahra, A., Lehtonen, A., and Huovinen, P. Colonization of resistant faecal aerobic Gram-negative bacilli among geriatric patients in hospital and the community. Journal of Antimicrobial Chemotherapy 37, 169-173 (1996).

38. Lester, S.C., de Pilar Pla, M., Wang, F., Perez SChael, I., Jiang, H., O’Brien, T.F. The carriage of Escherichia coli resistant to antimicrobial agents by healthy children in Boston, in Caracas, Venezuela, and in Qin Pu, China. N Engl J Med 323, 285-9 (1990).

39. Levin B.R, Lipsitch, M., Perrot, V., Schrag, S., Antia, R., Simonsen, L., Walker, N.M., and Stewart, F.M. The population genetics of antibiotic resistance. clinical infectious diseases 24, s9-s16 (1997).

40. Levin, S.A. and Andreasen, V. Disease transmission dynamics and the evolution of antibiotic resistance in hospitals and communal settings - Commentary. Proc Nat Ac Sc USA 96, 800-801 (1999).

41. Levy, S.B. Antibiotic resistance: an ecological imbalance. Ciba Found Symp 207, 1-9; discussion 9-14 (1997).

42. Lipsitch, M., Bergstrom, C.T., and Levin, B.R. The epidemiology of antibiotic resistance in hospitals: Paradoxes and prescriptions. Proc Nat Ac Sc USA 97, 1938-1943 (2000).

43. London, N., Nijsten, R., van der Bogaard, A., and Stobberingh, E. Carriage of antibiotic-resistant Escherichia coli by healthy volunteers during a 15-week period. Infection 22, 187-92 (1994).

44. London, N., Nijsten, R., vd Bogaard, A., and Stobberingh, E. Antibiotic resistance of faecal Enterobacteriaceae isolated from healthy volunteers, a 15-week follow-up study. J Antimicrob 
Chemother 32, 83-91 (1993).

45. Maiden, M. Horizontal genetic exchange, evolution, and spread of antibiotic resistance in bacteria. clinical infectious diseases 27, s12-s20 (1998).

46. McGowan, J.E. Drug resistance and nosocomial infections: epidemiology and prevention strategies. Baillieres Clin Infect Dis 5, 177-192 (1999).

47. Miller, Y.W., Eady, E.A., Lacey, R.W., Cove, J.H., Joanes, D.N., and Cunliffe, W.J. Sequential antibiotic therapy for acne promotes the carriage of resistant staphylococci on the skin of contacts. J Antimicrob Chemother 38, 829-37. (1996).

48. Murray, B.E. Problems and dilemmas of antimicrobial resistance. Pharmacotherapy 12, 86s-93s (1992).

49. Noble, W.C., Virani, Z., and Cree, R.G. Co-transfer of vancomycin and other resistance genes from Enterococcus faecalis NCTC 12201 to Staphylococcus aureus. FEMS Microbiol Lett 72, 195-8 (1992).

50. Olofsson, M.B., Pornull, K.J., Karnell, A., Telander, B., and Svenungsson, B. Fecal carriage of vancomycin- and ampicillin-resistant Enterococci observed in Swedish adult patients with diarrhea but not among healthy subjects. Scandinavian Journal of Infectious Diseases 33, 659-662 (2001). 51. Osterblad, M., Hakanen, A., Manninen, R., Leistevuo, T., Peltonen, R., Meurman, O. et al. A between-species comparison of antimicrobial resistance in enterobacteria in fecal flora. Antimicrob Agents Chemother 44, 1479-1484 (2000).

52. Pantosti, A., Del Grosso, M., Tagliabue, S., Macri, A., and Caprioli, A. Decrease of vancomycinresistant enterococci in poultry meat after avoparcin ban. Lancet 354, 741-2 (1999).

53. Reves, R.R., Fong, M., Pickering, L.K., Bartlett, A $3^{\text {rd }}$, Alvarez, M., and Murray, B.E. Risk factors for fecal colonization with trimethoprim-resistant and multiresistant Escherichia coli among children in day-care centers in Houston, Texas. Antimicrob Agents Chemother 34, 1429-34 (1990).

54. Robredo, B. Vancomycin-resistant enterococci isolated from animals and food. Int J Food Microbiol 54, 197-204 (2000).

55. Rydberg, J. and Cederberg, A. Intrafamilial spreading of Escherichia coli resistant to trimethoprim. Scand J Infect Dis 18, 457-60 (1986).

56. Savelkoul, P.H., Aarts, H.J., de Haas, J., Dijkshoorn, L., Duim, B., Otsen, M., Rademaker, J.L., Schouls, L., and Lenstra, J.A. Amplified-fragment length polymorphism analysis: the state of an art. J Clin Microbiol 37, 3083-91 (1999).

57. Schouten, M.A., Willems, R.J., Kraak, W.A., Top, J., Hoogkamp-Korstanje, J.A., and Voss, A. Molecular analysis of Tn1546-like elements in vancomycin-resistant enterococci isolated from patients in Europe shows geographic transposon type clustering. Antimicrob Agents Chemother 45, 986-9. (2001).

58. Seppala, H., Klaukka, T., Vuopio-Varkila, J., Muotiali, A., Helenius, H., Lager, K., and Huovinen,

P. The effect of changes in the consumption of macrolide antibiotics on erythromycin resistance in 
group A streptococci in Finland. Finnish Study Group for Antimicrobial Resistance. N Engl J Med 337, 441-6 (1997).

59. Shanahan, P.M., Thomson, C.J., and Amyes, S.G. Beta-lactam resistance in normal faecal flora from South Africa. Epidemiol Infect 115, 243-53 (1995).

60. Shanahan, P.M., Wylie, B.A., Adrian, P.V., Koornhof, H.J., Thomson, C.J., and Amyes, S.G. The prevalence of antimicrobial resistance in human faecal flora in South Africa. Epidemiol Infect 111 , 221-8 (1993).

61. Sievert, D et al. Staphylococcus aureus resistant to vancomycin-United States 2002. MMWR 51, 565-567 (2002).

62. Simonsen, G.S., Andersen, B.M., Digranes, A., Harthug,S., Jacobsen, T., Lingaas, E. et al. Low faecal carrier rate of vancomycin resistant enterococci in Norwegian hospital patients. Scandinavian Journal of Infectious Diseases 30, 465-468 (1998).

63. Sorensen, T.L. and Monnet, D. Control of antibiotic use in the community: The Danish experience. Infect Contr Hosp Epidemiol 21, 387-389 (2000).

64. Stobberingh, E., van den Bogaard, A., London, N., Driessen, C., Top, J., and Willems, R. Enterococci with glycopeptide resistance in turkeys, turkey farmers, turkey slaughterers, and (sub)urban residents in the south of The Netherlands: evidence for transmission of vancomycin resistance from animals to humans? Antimicrob Agents Chemother 43, 2215-21. (1999).

65. Struelens, M.J. The epidemiology of antimicrobial resistance in hospital acquired infections: problems and possible solutions. BMJ 317, 652-654 (1998).

66. Summers, A.O. Generally overlooked fundamentals of bacterial genetics and ecology. Clin Infect Dis 34 Suppl 3, S85-92 (2002).

67. van den Bogaard A.E., and Stobberingh, E.E. Antibiotic use in animals Impact on bacterial resistance and public health. Drugs 58, 589-607 (1999).

68. van de Mortel, H.J., Jansen, E.J., Dinant, G.J., London, N., Palacios Pru, E., and Stobberingh, E.E. The prevalence of antibiotic-resistant faecal Escherichia coli in healthy volunteers in Venezuela. Infection 26, 292-7 (1998).

69. van den Bogaard, A.E., Bruinsma, N., and Stobberingh, E.E. The effect of banning avoparcin on VRE carriage in The Netherlands. J Antimicrob Chemother 46, 146-148 (2000).

70. van den Bogaard, A.E., Jensen, L.B., and Stobberingh, E.E. Vancomycin-resistant enterococci in turkeys and farmers. N Engl J Med 337, 1558-9 (1997).

71. van den Bogaard, A.E., London, N., Driessen, C., and Stobberingh, E.E. Antibiotic resistance of faecal Escherichia coli in poultry, poultry farmers and poultry slaughterers. J Antimicrob Chemother 47, 763-771 (2001).

72. van den Bogaard, A.E. and Stobberingh, E.E. Antibiotic usage in animals - Impact on bacterial resistance and public health. DRUGS 58, 589-607 (1999).

73. van den Bogaard, A.E. Public health aspects of bacterial resistance in food animals. (2000). 
74. van den Bogaard, A., London, N., and Stobberingh, E.E. Antimicrobial resistance in pig faecal samples from The Netherlands (five abattoirs) and Sweden. J Antimicrob Chemother 45, 663-671 (2000).

75. van den Braak, N., Ott, A., van Belkum, A., Kluytmans, J.A., Koeleman, J.G., Spanjaard, L. et al. Prevalence and determinants of fecal colonization with vancomycin-resistant enterococcus in hospitalised patients in the Netherlands. Infect Contr Hosp Epidemiol 21, 520-524 (2000).

76. van den Braak, N., van Belkum, A., van Keulen, M., Vliegenhart, J., Verbrugh, H.A., and Endtz, H.P. Molecular characterization of vancomycin-resistant enterococci from hospitalised patients and poultry products in The Netherlands. J Clin Microbiol 36, 1927-32 (1998).

77. Vancanneyt, M., Lombardi, A., Andrighetto, C., Knijff, E., Torriani, S., Bjorkroth, K.J. et al. Intraspecies genomic groups in Enterococcus faecium and their correlation with origin and pathogenicity. Appl Environ Microbiol 68, 1381-91 (2002).

78. Vatopoulos A.C., Varvaresou, E., Petridu, E., Moustaki,M., Kyriakopoulos, M., Kapogiannis, D. et al. high rates of antibiotic resistance among normal fecal flora escherichia coli isolates in chidren from Greece. clin microbiol infect 4, 563-569 (1998).

79. Willems, R.J., Top, J., van den Braak, N., van Belkum, A., Endtz, H., Mevius, D. et al. Host specificity of vancomycin-resistant Enterococcus faecium. J Infect Dis 182, 816-23. (2000).

80. Willems R.J.L., Top, J., van den Braak, N., van Belkum, A., Mevius, D.J., Hendriks, G. et al. Molecular diversity and evolutionary realtionships of Tn1546-like elements in enterococci from humans and animals. Antimicrobial agents and chemotherapy 43, 483-491 (1999).

81. Witte, W. Medical consequences of antibiotic use in agriculture. Science 279, 996-7. (1998). 82. Woodford, N., Adebiyi, A.M., Palepou, M.F., and Cookson, B.D. Diversity of VanA glycopeptide resistance elements in enterococci from humans and nonhuman sources. Antimicrob Agents Chemother 42, 502-8. (1998). 


\section{CHAPTER 2}

\section{Antibiotic Use and the Prevalence of Antibiotic Resistance of healthy volunteers in the Dutch Community}

N. Bruinsma ', E. Stobberingh ${ }^{1}$, P. de Smet ${ }^{2}$, A. van den Bogaard ${ }^{1}$

1) Department of Medical Microbiology, University Hospital Maastricht, The Netherlands.

${ }^{2)}$ Stichting Farmaceutische Kengetallen, WINAp, The Hague, The Netherlands 


\begin{abstract}
Although most antibiotics are consumed in the community $(80 \%)$, the relation of antibiotic consumption and resistance in the community has been less thoroughly studied.

In the present study, antibiotic use was related to the prevalence of antibiotic resistance of $E$. coli and enterococci isolated from healthy volunteers living in the south of the Netherlands in 1996 and 1999.

No change of the total antibiotic use in the Dutch community was observed between 1996 and 1999 (3,542 and 3,598 DDD/1000 inhabitants/year). However, the increased fluoroquinolone use $(+18 \%)$ and the increased prevalence of ciprofloxacin resistance from zero to $2 \%$ is a point of concern, especially since this was accompanied by a significant shift towards higher MIC values $(\mathrm{p}<0.05)$. A significant decrease in the prevalence of vancomycin resistant enterococci $(\mathrm{p}<0.05)$ and a significant shift towards lower MIC values for avoparcin, a glycopeptide previously used as growth promoter in animal husbandry, was found $(\mathrm{p}<0.05)$. This was very likely the result of the banning of avoparcin for this purpose from April 1997.

In order to maintain the low level of antibiotic use and resistance in the Netherlands, surveillance of antibiotic resistance in non-clinical isolates in relation to antibiotic use is very important.
\end{abstract}

Key words: community, antibiotic resistance, antibiotic use, E. coli, enterococci. 


\section{INTRODUCTION}

Antibiotic resistance has become a major clinical and public health problem. We are currently faced with (multi) resistant bacteria that are difficult and sometimes impossible to treat ', especially in hospitals. However the development of bacterial resistance is not only confined to hospitals but should be considered an environmental problem. Especially since most antibiotics are consumed outside the hospital, accounting for $80 \%$ to $90 \%{ }^{2}$ of antibiotic use in European countries, selection of resistant commensal bacteria inevitably takes place in the community ${ }^{3}$. Besides the high amounts of antibiotics used in the community for human medicine, approximately $50 \%$ of all antibacterial agents used yearly in the European Union (EU) ${ }^{4}$ and more than $80 \%$ in the USA are given to animals ${ }^{5}$. Based on the observations in several studies these resistant bacteria and/or their resistance genes can be transferred from animals to humans either via direct contact e.g. farmers and slaughterers, or indirectly via the food chain ${ }^{6-8}$.

There is increasing evidence that commensal intestinal bacteria of humans, but also of animals play an important, but underappreciated role in bacterial resistance in human medicine ${ }^{3}$. Commensal bacteria themselves can cause endogenous infections, but the main threat is that they can transfer their resistance to potentially pathogenic bacteria passing through the gut ${ }^{9-13}$.

In addition, changes in resistance of the normal commensal flora can be considered as an early warning system for resistance to be expected in potentially pathogenic bacteria ${ }^{8,14}$. Therefore, surveillance of antibiotic resistance in non-clinical isolates in relation to antibiotic use is important, as it provides epidemiological data to set up and control antibiotic guidelines and make timely intervention feasible. In this study, antibiotic use in 1996 and 1999 was related to the prevalence of antibiotic resistance in the faecal indicator bacteria, E. coli and enterococci, -the main facultative aerobic inhabitants of the faecal commensal flora in humans-, ${ }^{8,11,15}$ isolated from healthy volunteers living in the south of the Netherlands. The prevalence of resistance was also compared with resistance data from the same region in $1992^{16}$. 


\section{MATERIALS AND METHODS}

\section{Antibiotic use}

Data on the use of antibiotics was obtained from the Institute of pharmaceutical data (Stichting Farmaceutische Kengetallen, SFK, The Hague, the Netherlands), which has the most extensive data on antibiotic use outside the hospital in the Netherlands. SFK retrieves its data from more than 1100 of the 1600 Dutch pharmacies. These 1600 pharmacies served around $91 \%$ of the total population in both 1996 and 1999 . The SFK converted the obtained data to an estimate of the total national antibiotic consumption in the Dutch community in DDD (defined daily dosage) per 1000 inhabitants per year.

\section{Population}

In, 1996 and 1999, 117 and 171 faecal samples were collected respectively from volunteers living in the south of the Netherlands (Weert/Roermond area). Using randomly selected addresses from the telephone directory written information about the aim of the study were sent to the participants and they were asked to sent in a faecal sample on the day of collection together with a questionnaire to the bacteriological laboratory of the University Hospital Maastricht. The questionnaire included questions about antibiotic use and hospitalisation three months preceding the sample collection. For comparative analysis the participants who had used antibiotics or had been hospitalised in the three months previous sample collection were excluded for further analysis. Prior to the study approval was obtained from the medical ethical committee of the University Hospital Maastricht.

\section{Sample processing}

On the day of arrival at the bacteriological laboratory one faecal sample of each participant was diluted $1: 10$ in $0.9 \%(\mathrm{w} / \mathrm{v}) \mathrm{NaCl}$ supplemented with $20 \%(\mathrm{v} / \mathrm{v})$ glycerol. The diluted samples were stored at $-20^{\circ} \mathrm{C}$ until assayed, as previously described ${ }^{17}$. In short, after thawing the samples were further diluted $\left(10^{-2}-10^{-3}-10^{-4}\right)$ and $0.04 \mathrm{ml}$ of these dilutions were inoculated onto agar plates without and with antibiotics using a spiral plater (Eddy Jet, IUL instruments, I.K.S., Leerdam, The 
Netherlands). The antibiotics and the concentrations used in the agar plates for $E$. coli (eosine methylene blue (EMB)-agar, Oxoid CM 69, Basingstoke, England) are shown in Table 1. Enterococci (streptococcus KF-agar, Oxoid CM701, Basingstoke, England) were tested against erythromycin $(10 \mu \mathrm{g} / \mathrm{ml}$ concentration used in the agar plates), dalfopristin-quinupristin $(5 \mu \mathrm{g} / \mathrm{ml})$, and vancomycin $(10 \mu \mathrm{g} / \mathrm{ml})$. The concentrations in the agar plates were based on NCCLS guidelines ${ }^{18}$ and modified (where appropriate) to make comparison with previous studies possible ${ }^{16,19,20}$. For enterococci, in addition to antibiotics used in human medicine also related compounds (previously) used as antimicrobial performance enhancers (AMGP) were tested.

\section{Prevalence of Antibiotic Resistance}

The prevalence of antibiotic resistance was defined as the number of faecal samples with resistant $E$. coli or enterococci divided by the total number of samples tested multiplied by $100 \%$. To determine the prevalence of dalfopristin/quinupristin resistant enterococci, the isolates identified as Enterococcus faecalis were excluded. The degree of resistance of each sample was defined as the ratio (in \%) between the number of colonies grown on the agar plates with and without antibiotics "

\section{Minimal Inhibitory Concentration (MIC) distributions}

In addition to the prevalence of resistance from one colony of $E$. coli or enterococcus, isolated from the agar plates without antibiotics, the antibiotic susceptibility as MIC value was determined using Iso-Sensitest broth ${ }^{\mathrm{TM}}$ (Oxoid CM 473, Basingstoke, England) an inoculum of $5 \times 10^{5} \mathrm{CFU} / \mathrm{ml}$ and an incubation time of $18-24 \mathrm{~h}$ at $37^{\circ} \mathrm{C}$. E. coli ATCC 25922 and Enterococcus faecalis ATCC 29212 were used as reference strains. The $E$. coli isolates were tested against amoxicillin, ciprofloxacin, nalidixic acid, nitrofurantoin, oxytetracycline and trimethoprim. The enterococci isolates were tested against amoxicillin, avoparcin, vancomcyin, erythromycin, tylosin and virginiamycin.

\section{Statistical analysis}

The chi-square test was used to analyse differences in the prevalence of resistant $E$. 
coli and enterococci sampled in 1992, 1996 and 1999 in Weert/Roermond. The MannWhitney test (2-tailed, $\mathrm{p}<0.05)$ was used to compare the MIC distributions of $E$. coli and enterococci sampled in 1996 and 1999.

\section{RESULTS}

\section{Antibiotic use}

No changes in the overall use of antibiotics between $1996(3,542 \mathrm{DDD} / 1000$ inhabitants/year) and 1999 (3,598 DDD/1000 inhabitants/year) was observed. However, between 1996 and 1999 an increase in consumption of some groups of antibiotic was observed: other penicillins (all penicillins besides aminopenicillins) (589 to $649 \mathrm{DDD} / 1000 \mathrm{inh} . / \mathrm{y}$ ), nitrofurantoin (207 to $231 \mathrm{DDD} / 1000 \mathrm{inh} . / \mathrm{y}$ ), fluoroquinolones ( 261 to $308 \mathrm{DDD} / 1000 \mathrm{inh} . / \mathrm{y}$ ), and macrolides \& lincosamides (353 to $447 \mathrm{DDD} / 1000 \mathrm{inh} / \mathrm{y}$ ) (Figure 1). In addition a decrease in consumption of aminopenicillins (800 to $745 \mathrm{DDD} / 1000 \mathrm{inh} . / \mathrm{y})$, cephalosporins (41 to 27 DDD/1000inh./y), tetracyclines ( 983 to $903 \mathrm{DDD} / 1000 \mathrm{inh} / \mathrm{y}$ ), trimethoprim (286 to $273 \mathrm{DDD} / 1000 \mathrm{inh} . / \mathrm{y}$ ) and quinolones (23 to $16 \mathrm{DDD} / 1000 \mathrm{inh} . / \mathrm{y}$ ) was observed. In both years tetracyclines were the most prescribed antibiotics, followed by aminopenicillins and other penicillins (Figure 1).

\section{Population characteristics}

In 1996, 117 faecal samples were collected from healthy participants living in the southern part of the Netherlands of which 13 samples were excluded for further analysis as they originated from participants who had used antibiotics in the 3 months preceding sample collection. In 1999, 171 samples were collected from participants living in the same area. Forty-two of the participants had been hospitalised $(n=12)$ and/or had used antibiotics $(\mathrm{n}=35)$, and therefore, were excluded for analysis. In total 104 and 129 samples were analysed in 1996 and 1999 respectively. The mean age of the populations analysed in both 1996 and 1999 was 55 years. 


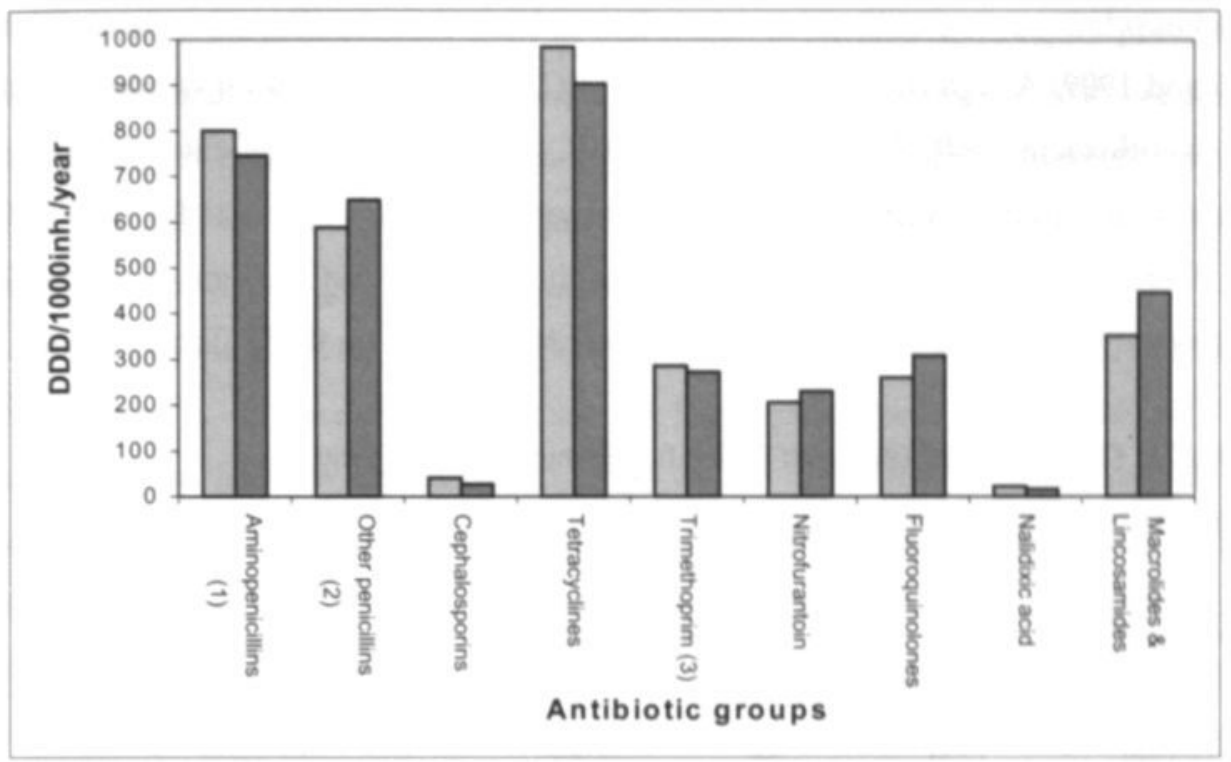

FIGURE 1. Antibiotic use in the Dutch community in 1996 ( 1 it ) and 1999 (

1) Penicillins with extended spectrum

2) B-lactamase sensitive penicillins, $B$-lactamase resistant penicillins, combinations of penicillins, including B-lactamase inhibitors.

3) trimethoprim and combinations of sulfonamides and trimethoprim

\section{Prevalence of antibiotic resistance}

No significant differences in the prevalence of resistant $E$. coli for the antibiotics tested were found between 1996 and 1999 for the group of participants. A tendency to a decrease in prevalence was found for amoxicillin resistance from $38 \%$ to $29 \%$, whereas an increase in prevalence was observed for ciprofloxacin and nalidixic acid resistance from no resistance in 1996 to $2 \%$ and 3\% respectively in 1999 (Table 1). The prevalence of enterococci resistant to quinupristin-dalfopristin and vancomycin decreased significantly over time from $24 \%$ and $11 \%$ to $12 \%$ and $3 \%$ respectively $(p<0.05$ ). The prevalence of erythromycin resistant enterococci was $42 \%$ and $47 \%$ for 1996 and 1999 respectively.

\section{MIC distributions}

No significant differences in MIC distributions of amoxicilllin, nitrofurantoin, 
oxytetracycline, and trimethoprim were observed between the $E$. coli isolates from 1996 and 1999. A significant shift to higher MIC values was found for nalidixic acid and ciprofloxacin $(\mathrm{p}<0.05$ ) (Table 2). The MIC distributions of the enterococci for vancomycin, virginiamycin, erythromycin and amoxicillin were similar for the 1996 and 1999 isolates. For both tylosin and avoparcin the MIC distributions of the 1999 isolates showed a significant shift towards lower MIC values $(\mathrm{p}<0.05)$ (Table 3 ).

TABLE 1. The prevalence (Prev.) of antibiotic resistance (\%) of faecal Escherichia coli in 1996 and 1999.

\begin{tabular}{llll}
\hline & & 1996 & 1999 \\
\cline { 3 - 4 } Antimicrobial & & $\mathrm{n}=104$ & $\mathrm{n}=129$ \\
agent & (conc. $\mu \mathrm{g} / \mathrm{ml})$ & Prev. & Prev. \\
\hline Amoxicillin & $(25)$ & 38 & 29 \\
Cefazolin & $(32)$ & $\mathrm{nt}$ & 9 \\
Ciprofloxacin & $(4)$ & 0 & 2 \\
Chloramphenicol & $(25)$ & $\mathrm{nt}$ & 9 \\
Gentamicin & $(16)$ & $\mathrm{nt}$ & 1 \\
Nalidixic acid & $(32)$ & 0 & 3 \\
Nitrofurantoin & $(50)$ & 0 & 0 \\
Oxytetracyclin & $(25)$ & 28 & 33 \\
Trimethoprim & $(8)$ & 18 & 19
\end{tabular}

\section{DISCUSSION}

No significant difference in total human antibiotic consumption outside hospitals was observed between 1996 and 1999. However, for macrolides and fluoroquinolones an increase of $27 \%$ and $18 \%$ respectively was found and the consumption of aminopenicillines, tetracyclines and trimethoprim slightly decreased.

\section{E. coli}

The increase in prevalence of ciprofloxacin resistance from $0 \%$ to $2 \%$ in healthy 
volunteers in the present study must be considered as an early warning for prudent use of fluoroquinolones, especially since a significant shift to higher MIC values for ciprofloxacin between isolates from 1996 to 1999 was already observed. Also for nalidixic acid the prototype of the quinolones an increase in prevalence of resistance and a shift towards higher MIC values was found.

Although in the Netherlands, the prevalence of fluoroquinolone resistant $E$. coli is still low, there is an increase in the use of fluoroquinolones. From 1990 till 1996 consumption had already increased from 154 to 277 DDD/1000 inhabitants/year respectively ${ }^{22}$. As new fluoroquinolones will/have become available for clinical use an even further increase in use is expected and consequently also a further increase in the prevalence of resistance ${ }^{23}$. In several European countries ciprofloxacin resistance rates in $E$. coli increased from less than $1 \%$ in 1989 to over $5 \%$ in several European countries and in a Spanish centre even to $18 \%{ }^{25}$. In the Barcelona community the prevalence of fluoroquinolone resistance has even reached $22 \%{ }^{24}$.

Both in 1996 and 1999 the prevalence of resistance to nitrofurantoin was zero. Despite the fact that this compound has been available for clinical use for more than fifty years a low prevalence of resistance has been reported in many studies all over the world ${ }^{26-}$ 31. This might be explained by the multiple mechanisms of action of nitrofurantoin on bacteria ${ }^{32}$. Also, despite the fact that R-plasmids have been described ${ }^{33}$, plasmid mediated resistance of nitrofurantoin remains rare.

In 1992 a similar study was performed analysing antibiotic resistance in $E$. coli among healthy individuals living in the same area, using the same method ${ }^{17}$. Comparing the prevalence of antibiotic resistant $E$. coli a significant decrease was observed for amoxicillin resistance from $1992(44 \%)$ to $1999(29 \%)(\mathrm{p}<0.05)$ (Figure 2). This decrease of amoxicillin resistance is difficult to explain as the consumption of amoxicillins remained unchanged and high from 1990 till $1996^{22}$. However the use of amoxicillin with clavulanic acid markedly increased ${ }^{22}$, eliminating amoxicillin resistant $\beta$-lactamase producing $E$. coli, and thereby possibly lowering the prevalence of amoxicillin resistant bacteria.

The prevalence of trimethoprim resistant $E$. coli were of the same size of order in 1996 and 1999 i.e. $18 \%$ and $19 \%$, and were higher compared to the $14 \%$ in $1992{ }^{16}$. These 
data could question the empiric choice of trimethoprim for the treatment of acute uncomplicated urinary tract infections as recommended by the NHG (Dutch Council of General Practitioners) ${ }^{34}$.

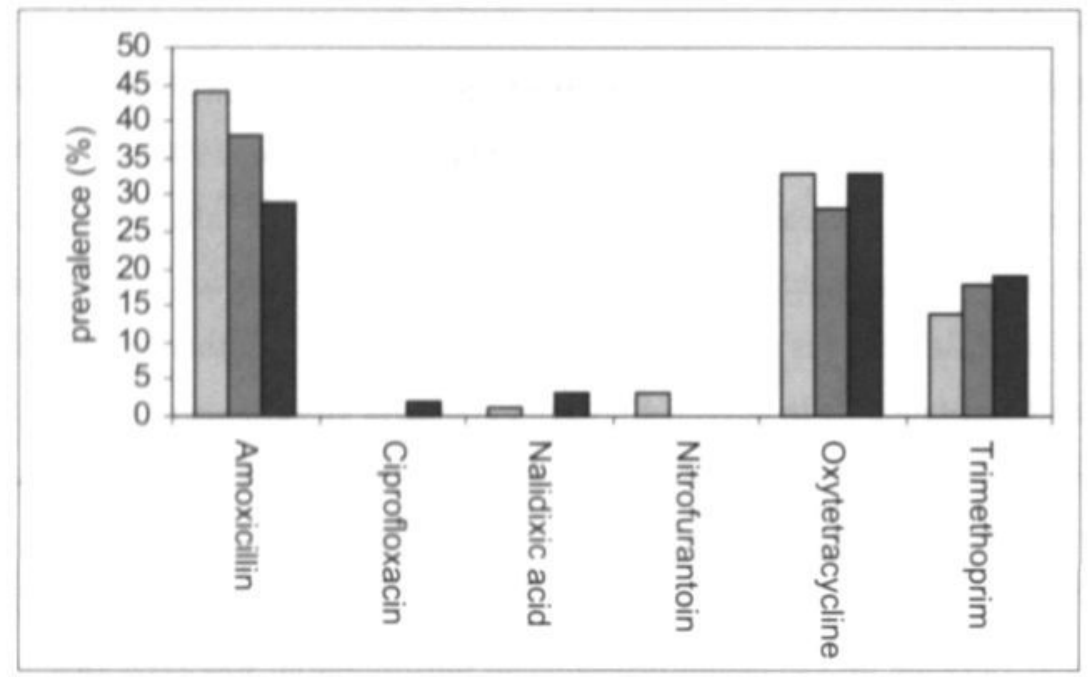

FIGURE 2. Prevalence of antibiotic resistant $E$. coli in 1992, 1996 and 1999 in the Dutch community: 1992 ( $\mathbf{m}$ ), 1996 ( $\mathbf{m}$ ), 1999 (

\section{Enterococci}

In the present study, the increased use did not result in a significant increase of erythromycin resistance in enterococci, as macrolides \& lincosamides are not the drug of choice for enterococci infections. The newer macrolides certainly have advantages, compared to erythromycin, but the worldwide increase in macrolide resistance of $S$. pneumoniae, the most important respiratory tract pathogen, is very likely due to the increased use of these agents ${ }^{35,36}$.

Tylosin a macrolide antibiotic, used as a growth promoter till april 1997 (EU ban) showed a significant shift towards lower MIC values from 1996 to 1999. However, although tylosin shows frequent cross-resistance with erythromycin ${ }^{37}$ no significant shift towards lower MIC values or a decrease in the prevalence of erythromycin 
resistance was found. Probably the decrease in use of tylosin was compensated by the increase in use of macrolides.

In Europe, including the Netherlands, vancomycin is hardly used outside hospitals. In addition the use of vancomycin in human medicine only slightly decreased in the Netherlands from 1996 to 1999 (1,145 and 935 DDD/1000 inhabitants/year respectively). As previously published, the most plausible explanation for the significant decrease in the prevalence of vancomycin resistance $(p<0.05)$ is the EU ban of avoparcin as antimicrobial growth promoter in april $1997^{21}$. In the present study an additional shift towards lower MIC values for avoparcin $(\mathrm{p}<0.05)$ was observed reinforcing the effect of the avoparcin ban. Avoparcin, an analogue of vancomycin, has been widely used as feed additive to promote growth in food animals and this use has resulted in the transmission of vancomycin resistance from animals to humans via the food chain ${ }^{6-8}$. After the ban several studies have described a decrease in prevalence of vancomycin resistant enterococci ${ }^{21 .}{ }^{38}$. In contrast to the previous study ${ }^{21}$, in the present study one the volunteers that used antibiotics in the 3 months preceding sample collection were excluded for analysis. Therefore some differences in the number of samples and the prevalence of resistant enterococci were observed, but this does not influence the overall results.

The observed decrease in quinupristin/dalfopristin resistant enterococci from $24 \%$ to $12 \%$ is most likely due to the fact that virginiamycin, an analogue compound used as a growth promoter, was in short supply in the Netherlands during 1997 and 1998 because of production problems of the manufacturer ${ }^{21}$. However no significant shift towards lower MIC values was observed for virginiamycin.

All enterococci were found susceptible to amoxicillin. This confirms that amoxicillin alone or in combination with aminoglycosides remains the drug of choice to treat enterococcal infections, both vancomycin resistant and susceptible.

In conclusion, in order to maintain the low level of antibiotic use and resistance in the Netherlands, surveillance of antibiotic resistance in non-clinical isolates in relation to antibiotic use is important, as it provides epidemiological data to set up and control antibiotic guidelines and serves as an early warning for resistance in pathogenic bacteria. 


\section{ACKNOWLEDGEMENTS}

This investigation was supported financially by ZorgOnderzoek Nederland (ZON), The Netherlands[97-1-104]. We thank C. Driessen and Dr. N. London for their expert technical assistance. 
TABLE 2. MIC distribution of E.coli isolated in $1996(\mathrm{n}=97)$ and $1999(\mathrm{n}=113)$

\begin{tabular}{|c|c|c|c|c|c|c|c|c|c|c|c|c|c|c|c|c|}
\hline \multirow{2}{*}{$\begin{array}{l}\text { Antimicrobial } \\
\text { agents }\end{array}$} & \multirow[t]{2}{*}{ year } & \multicolumn{9}{|c|}{ Percentage of isolates inhibited by concentration $(\mathrm{mg} / \mathrm{l})$} & \multicolumn{3}{|c|}{ ( $\mid$ = breakpoint $)$} & \multirow[t]{2}{*}{$\mathrm{MIC}_{50}$} & \multirow[t]{2}{*}{$\mathrm{MIC}_{\text {, }}$} & \multirow[t]{2}{*}{ Range } \\
\hline & & 0.25 & 0.5 & 1 & 2 & 4 & 8 & 16 & 32 & 64 & 128 & 256 & 512 & & & \\
\hline \multirow[t]{2}{*}{ Amoxicillin } & 1996 & & & & & 74 & 9 & $1 \mid$ & 1 & 0 & 0 & 8 & 6 & 4 & 256 & $4-512$ \\
\hline & 1999 & & & & & 69 & 3 & 21 & 0 & 0 & 0 & 7 & 20 & 4 & 512 & $4-512$ \\
\hline \multirow[t]{2}{*}{ Ciprofloxacin* } & 1996 & 100 & 0 & 0 & 01 & 0 & 0 & 0 & 0 & & & & & 0.25 & 0.25 & 0.25 \\
\hline & 1999 & 94 & 1 & 0 & 01 & 4 & 1 & 1 & 0 & & & & & 0.25 & 0.25 & $0.25-16$ \\
\hline \multirow[t]{2}{*}{ Nalidixic acid* } & 1996 & & 62 & 33 & 4 & 1 & 0 & 0 & 0 & 0 & & & & 0.5 & 1 & $0.5-4$ \\
\hline & 1999 & & 3 & 14 & 52 & 20 & 1 & $0 \mid$ & 1 & 10 & & & & 2 & 32 & $0.5-64$ \\
\hline \multirow[t]{2}{*}{ Nitrofurantoin } & 1996 & & & 0 & 0 & 1 & 30 & 67 & 2 & 01 & 0 & & & 16 & 16 & $4-32$ \\
\hline & 1999 & & & 1 & 1 & 2 & 20 & 68 & 8 & 11 & 0 & & & 16 & 16 & $1-64$ \\
\hline \multirow[t]{2}{*}{ Oxytetracycline } & 1996 & & & & 71 & 11 & 11 & 0 & 0 & 0 & 0 & 17 & & 2 & 256 & $2-256$ \\
\hline & 1999 & & & & 68 & 1 & $0 \mid$ & 1 & 2 & 1 & 5 & 22 & & 2 & 256 & $2-256$ \\
\hline \multirow[t]{2}{*}{ Trimethoprim } & 1996 & & & 87 & $0 \mid$ & 0 & 0 & 0 & 6 & 7 & 0 & & & 1 & 32 & $1-64$ \\
\hline & 1999 & & & 83 & 21 & 0 & 0 & 0 & 11 & 4 & 0 & & & 1 & 32 & $1-64$ \\
\hline
\end{tabular}

$\bullet p<0.05$ 
TABLE 3. MIC distribution of enterococci isolated in $1996(\mathrm{n}=97)$ and $1999(\mathrm{n}=116)$

\begin{tabular}{|c|c|c|c|c|c|c|c|c|c|c|c|c|c|c|}
\hline \multirow{2}{*}{$\begin{array}{l}\text { Antimicrobial } \\
\text { agents }\end{array}$} & \multirow[t]{2}{*}{ year } & \multicolumn{10}{|c|}{ Percentage of isolates inhibited by concentration $(\mathrm{mg} / 1)(\mid=$ breakpoint $)$} & \multicolumn{3}{|c|}{$\mathrm{MIC}_{s_{0}} \mathrm{MIC}_{90}$ Range } \\
\hline & & 0.25 & 0.5 & 1 & 2 & 4 & 8 & 16 & 32 & 64 & 128 & & & \\
\hline \multirow[t]{2}{*}{ Amoxicillin } & 1996 & & & 94 & 2 & 2 & 2 & $0 \mid$ & 0 & 0 & 0 & 1 & 1 & $1-8$ \\
\hline & 1999 & & & 96 & 3 & 0 & 0 & 0 & 0 & 0 & 1 & 1 & 1 & $1-128$ \\
\hline \multirow[t]{2}{*}{ Avoparcin* } & 1996 & & 3 & 21 & 27 & 36 & 10 & 4 & 0 & 0 & & 2 & 8 & $0.5-16$ \\
\hline & 1999 & & 55 & 28 & 12 & 31 & 0 & 0 & 0 & 2 & & 0.5 & 2 & $0.5-64$ \\
\hline \multirow[t]{2}{*}{ Vancomycin } & 1996 & & & 73 & 12 & 11 & 2 & $0 \mid$ & 0 & 0 & 2 & 1 & 4 & $1-128$ \\
\hline & 1999 & & & 83 & 8 & 5 & 3 & 0 & 0 & 0 & 2 & 1 & 2 & $1-128$ \\
\hline \multirow[t]{2}{*}{ Erythromycin } & 1996 & & 26 & 11 & 24 & 111 & 10 & 1 & 1 & 17 & & 2 & 64 & $0.5-64$ \\
\hline & 1999 & & 32 & 11 & 23 & 16 & 6 & 0 & 0 & 11 & & 2 & 64 & $0.5-64$ \\
\hline \multirow[t]{2}{*}{ Tylosin* } & 1996 & & 3 & 10 & 40 & 24 & 4 & 1 & 0 & 18 & & 2 & 64 & $0.5-64$ \\
\hline & 1999 & & 12 & 32 & 30 & $13 \mid$ & 2 & 0 & 0 & 11 & & 2 & 64 & $0.5-64$ \\
\hline \multirow[t]{2}{*}{ Virginiamycin } & 1996 & & & 63 & 12 & 12 & 111 & 1 & 1 & 0 & 0 & 1 & 8 & $1-32$ \\
\hline & 1999 & & & 64 & 16 & 17 & 21 & 1 & 1 & 0 & 0 & 1 & 4 & $1-32$ \\
\hline
\end{tabular}

$* \mathrm{p}<0.05$ 


\section{REFERENCES}

1. Levy SB: Factors impacting on the problems of antibiotic resistance. J. Antimicrob. Chemother. 2002;49:25-30.

2. Serensen TL, Monnet D: Control of antibiotic use in the community: the Danish experience. Infect. Contr. Hosp. Epidemiol. 2000;21:387-389.

3. Reservoirs of Antibiotic Resistance Network (ROAR) report: Commensal bacteria- an important reservoir of antibiotic resistance genes? A position paper from the Working Group on Antibiotic Resistance in Commensal Bacteria, September 1998.

4. Van den Bogaard AE, Stobberingh EE: Antibiotic use in animals: impact on bacterial resistance and public health. Drugs 1999;58:589-607.

5. Mellon N, Benbrook C, Benbrook KL: Hogging it: Estimates of antimicrobial abuse in livestock. Union of Concerned Scientists, January 2001.

6. Klare I, Heier H, Claus H, Bohme G, Marin S, Seltmann, G. et al: Enterococcus faecium strains with vanA-mediated high-level glycopeptide resistance isolated from animal foodstuffs and fecal samples of humans in the community. Microb. Drug Resist. 1995;1:265-272.

7. Willems RJ, Top J, van den braak N, van Belkum A, Endtz H, Mevius D, Stobberingh E, van den Bogaard A, van Embden JD:Host specifity of vancomycin-resistant Enterococcus faecium. J Infect. Dis. 2000;182:816-23.

8. Van den Bogaard AE, London N, Stobberingh EE: Antimicrobial resistance in pig faecal samples from The Netherlands (five abattoirs) and Sweden. J. Antimicrob. Chemother. 2000;45:663-671.

9. Österblad M, Hakanen A, Manninen R, Leistevuo T, Peltonen R, Meurman O, Huovinen P, Kotilainen P: A between-species comparison of antimicrobial resistance in enterobacteria in fecal flora. Antimicrob. Agents Chemother. 2000;44:1479-1484.

10. Shanahan PMA, Thomson J, Amyes SGB: B-Lactam resistance in normal faecal flora from South Africa. Epidemiol. Infect. 1995;115:243-253.

11. Levy SB, Marschall B, Schleuderberg S, Rowse D, Davies J: High frequency of antimicrobial resistance in human fecal flora. Antimicrob. Agents Chemother. 1988;32:1801-1806.

12. Van den Bogaard AE, Stobberingh EE: Vancomycin resistant enterococci in turkeys and farmers. New Engl. J. Med. 1997;337:1558-1559.

13. Vatopoulos AC, Varvaresou E, Petridou E, Moustaki M, Kyiakopoulos M, Kapogiannis D, Sarafoglou S, Fretzagias A, Kalapothaki V: High rates of antibiotic resistance among normal fecal flora Escherichia coli isolates in children from Greece. Clin. Microbiol. Infect. 1998;4:563-569.

14. Lester SC, Pilar Pla del M, Wang F, Prez Schael I, Jiang H, O'Brien TF: The carriage of Escherichia coli resistant to antimicrobial agents by healthy children in Boston, in Caracas, Venezuela, and Qin Pu, China. New Engl. J. Med. 1990;323:285-289. 
15. Van de Mortel HJE, Jansen EJP, Dinant GJ, London N, Palacios Prü E, Stobberingh EE: The prevalence of antibiotic-resistant faecal Escherichia coli in healthy volunteers in Venezuela. Infection 1998;26:292-297.

16. London N, Nijsten R, van den Bogaard A, Stobberingh E: Carriage of antibiotic-resistant Escherichia coli by healthy volunteers during a 15-week period. Infection 1994;22:187-192.

17. London N, Nijsten R, Van den Bogaard A, Stobberingh E: Antibiotic resistance of faecal enterobacteriaceae isolated from healthy volunteers, a 15-week follow-up study. J. Antimicrob. Chemother. 1993;32:83-91.

18. National Committee for Clinical Laboratory Standards: Performance standards for antimicrobial susceptibility testing: eight informational supplement. NCCLS, 940 West Valley Road, Pensylvania 1998, USA.

19. Nijsten R, London N, Van den Bogaard A, Stobberingh E: Resistance in faecal Escherichia coli isolated from pig farmers and abattoir workers. Epidemiol. Infect. 1994:113:45-52.

20. Bonten M, Stobberingh E, Philips J, Houben A: High prevalence of antibiotic resistant Escherichia coli in faecal samples of students in the south-east of The Netherlands. J. Antimicrob. Chemother. 1990;26:585-592.

21. Van den Bogaard AE, Bruinsma N, Stobberingh EE: The effect of banning avoparcin on VRE carriage in The Netherlands. J. Antimicrob. Chemother. 2000;46:145-153.19.

22. De Neeling AJ: Antibioticagebruik en het optreden van resistentie. In: Volksgezondheid Toekomst Verkenning. Elsevier/De Tijdstroom, Maarssen 1997, pp 793-800.

23. Goettsch W, van Pelt W, Nagelkerke N, Hendrix MGR, Buiting AGM, Petit PL, Sabbe LJ, van Griethuysen AJ, de Neeling AJ: Increasing resistance to fluoroquinolones in Escherichia coli from urinary tract infections in the Netherlands. J. Antimicrob. Chemother. 2000;46:223-228.

24. Garau J, Xercavins M, Rodriguez-Carballeira M, Gomez-Vera JR, Coll I, Vidal D, Llovet T, RuizBremon A: Emergence and dissemination of quinolone-resistant Escherichia coli in the community. Antimicrob. Agents Chemother. 1999;43:2736-2741.

25. Guyot A, Threlfall EJ, Hampton MD, Cheasty TJ: Molecular epidemiology of multi-resistant Escherichia coli. J. Hosp. Infect. 1999;43:39-48.

26. Kahlmeter G: The ECO.SENS project: a prospective, multinational, multicentre epidemiologcal survey of the prevalence and antimicrobial susceptibility of urinary tract pathogens - interim report. J. Antimicrob. Chemother. 2000;46 (Suppl 1):15-22.

27. Gupta K, Scholes D, Stamm WE: Increasing prevalence of antimicrobial resistance among uropathogens causing acute uncomplicated cystitis in women. JAMA 1999:282:325-326.

28. Vromen M, van der Ven AJ, Knols A, Stobberingh EE: Antimicrobial resistance patterns in urinary isolates from nursing home residents. Fifteen years of data reviewed. J. Antimicrob. Chemother. 1999;44:113-116. 
29. Zhanel GG, Karlowsky JA, Harding GK, Carrie A, Mazzulli T, Low DE, Hoban DJ: A canadian national surveillance study of urinary tract isolates from outpatients: comparison of the activities of trimethoprim-sulfamethoxazole, ampicillin, mecillinam, nitrofurantoin, and ciprofloxacin. The Canadian Urinary Isolate Study Group. Antimicrob. Agents Chemother. 2000;44:1089-1092.

30. Valdivieso F, Trucco O, Prado V, Diaz MC, Ojeda A: Antimicrobial resistance of agents causing urinary tract infections in 11 Chilean hospitals. PRONARES project. Rev. Med. Chil. 1999;127:103340.

31. Chomarat M: Resistance of bacteria in urinary tract infections. Internat. J. Antimicrob. Agents 2000;16:483-387.

32. McOsker CC, Fitzpatrick PM: Nitrofurantoin: mechanism of action and implications for resistance development in common uropathogens. J. Antimicrob. Chemother. 1994;33(suppl A):23-30.

33. Breeze AS, Obaseiki-Ebor EE: Transferable nitrofuran resistance conferred by R-plasmids in clinical isolates of Escherichia coli. J. Antimicrob, Chemother. 1983;12:459-467.

34. Wiersma TJ, Timmermans AE:Summary of the 'Urinary tract infections'guideline (first revision) of the Dutch College of General Practitioners [Article in Dutch]. Ned. Tijschr. Geneesk. 2001;145:720-6.

35. Fitoussi F, Doit C, Gesin P, Btahimi N, Bingen E: Mechanisms of macrolide resistance in clinical pneumococcal isolates in France. Antimicrob. Agents Chemother. 2001;45:636-638.

36. Seppälä H, Klaukka T, Vuopio-Varkila J, Muotiala A, Helenius H, Lager K, Huovinen P: The effect of changes in the consumption of macrolide antibiotics on erythromycin resistance in group A streptococci in Finland. The New Engl. J. Med. 337, 441-446.

37. Pechere JC: Streptogramins; a unique class of antibiotics. Drugs 1996;51 (Suppl. 1):13-19.

38. Klare I, Badstübner D, Konstabel C, Böhme G, Claus H, Witte W: Decreased incidence of vanAtype vancomycin-resistant enterococci isolated from poultry meat and from fecal samples of humans in the community after discontinuation of avoparcin usage in animal husbandry. Microb. Drug Resist. $1999 ; 5: 45-5$ 


\section{CHAPTER 3}

\section{Antibiotic Usage and Resistance in different regions of the Dutch Community}

N. Bruinsma', P. M. G. Filius ${ }^{2}$, P. A. G. M. de Smet $^{3}$, J. Degener ${ }^{4}$, Ph. Endtz $^{2}$, A. E. van den Bogaard', E. E. Stobberingh'

${ }^{1)}$ Department of Medical Microbiology, University Hospital Maastricht, Maastricht, The Netherlands,

${ }^{2)}$ Department of Medical Microbiology and Infectious Diseases, Erasmus Medical Centre, Rotterdam, The Netherlands,

${ }^{3)}$ Scientific Institute Dutch Pharmacists, The Hague, the Netherlands

${ }^{\text {and }}$ Department of Clinical Pharmacy, University Medical Centre St Radboud, Nijmegen, the Netherlands,

${ }^{4)}$ Department of Medical Microbiology, University Hospital Groningen, Groningen, The Netherlands.

Microbial Drug Resistance, 2002, Volume 8, Issue number 3 (Fall);209-214 


\begin{abstract}
Regional differences of antibiotic use and antibiotic resistance in the faecal indicator bacteria Escherichia coli and enterococci were determined in different cities in the south, west and north of the Netherlands. In 1999 differences in antibiotic consumption were observed between the different regions: 11.19, 10.84 and 7.16 DDD (defined daily dosage) per 1000 inhabitants per day, respectively. No significant regional differences were found in the prevalence of antibiotic resistance for both $E$. coli and enterococci. However, the differences in antibiotic consumption observed might lead to changes in antibiotic resistance in the near future. Surveillance of antibiotic use and antibiotic resistance is strongly recommended to control the development of antibiotic resistance as it provides epidemiological data to set up and control antibiotic guidelines.
\end{abstract}




\section{INTRODUCTION}

Many studies have proven a relation between antibiotic use and antibiotic resistance in clinical isolates, especially in the hospital environment. ${ }^{3,11,21,29,30,43}$ Although most antibiotics are consumed in the community $(80 \%),{ }^{41}$ the relation of antibiotic consumption and resistance in the community has been less thoroughly studied. Use of antibiotics in the community may lead to an increased resistance in (nonclinical) commensal intestinal bacteria. ${ }^{37}$ Besides the fact that commensal bacteria can cause endogenous infections themselves, ${ }^{40,48}$ they can also transfer their resistance genes to potentially pathogenic bacteria passing through the human gut. $^{40,44,48}$

Therefore, surveillance of antibiotic resistance in indicator bacteria of the intestinal flora of healthy individuals in the community is very important as it can serve as an early warning system of resistance in pathogenic bacteria. ${ }^{46}$ In addition, surveillance of antibiotic use and antibiotic resistance provides epidemiological data to set up and control antibiotic guidelines. $2,15,28$

The relation between antibiotic use and antibiotic resistance is very complex. Differences in prescribing habits, antibiotic policies and socio-economic variables can influence the consumption of antibiotics and consequently the development of antibiotic resistance. Moreover, the spread of resistant bacteria and resistance genes can be influenced by several factors such as poor sanitation, crowding, travelling and grouping of susceptible persons, i.e., elderly and children. ${ }^{20,33,38}$

Various studies have analysed the relation between antibiotic use ${ }^{5}$ and resistance in the community, over time, ${ }^{6,24,27,32}$ and between different countries. ${ }^{19}$ Others described the effect of altering antibiotic prescribing policies on antibiotic resistance. $7,9,12,39$ Regional differences of antibiotic use and antibiotic resistance within a country have been less thoroughly studied ${ }^{16,17}$.

In the present study, the prevalence of antibiotic resistance of faecal indicator bacteria Escherichia coli and enterococci isolated from healthy individuals living in three different regions of the Netherlands were determined and the influence of regional antibiotic consumption on the prevalence of resistance was studied. 


\section{MATERIALS AND METHODS}

\section{Regional data}

In the south, west and north of the Netherlands the cities of Weert \& Roermond, Rotterdam and Groningen respectively were included. Data on the number of inhabitants, age distribution, population density, and socio-economic variables of the three regions were obtained from the Central Bureau of Statistics (CBS).

The antibiotic consumption in defined daily doses (DDD) per 1000 inhabitants per day (DID) in 1999 for the three regions were obtained from the Scientific Institute of Dutch Pharmacists (SFK, The Hague, the Netherlands). SFK has the most extensive data on antibiotic use in the Netherlands outside the hospital and retrieves its data from more than 1100 of the 1600 Dutch general pharmacists. These 1600 pharmacies served around $91 \%$ of the total population in 1999. SFK converts the data retrieved from the pharmacies of a specific region to estimate the total regional antibiotic consumption.

\section{Study population}

In 1999, 600 inhabitants from the three cities were randomly selected from the telephone directory. They were informed by letter about the aim of the study and were asked to sent in a faecal sample on the day of collection together with a questionnaire to the bacteriological laboratory of the University Hospital Maastricht. The questionnaire included questions about age, antibiotic use and hospitalisation three months preceding the sample collection.

Prior to the start of the study approval was obtained by the Medical Ethical Committee of the University Hospital Maastricht.

\section{Sample processing}

On the day of arrival at the bacteriological laboratory the faecal samples were diluted 1:10 in $0.9 \%(\mathrm{w} / \mathrm{v}) \mathrm{NaCl}$ supplemented with $20 \%(\mathrm{v} / \mathrm{v})$ glycerol. The diluted samples were stored at $-20^{\circ} \mathrm{C}$ until assayed, as previously described. ${ }^{25}$ In short, after thawing the samples were further diluted $\left(10^{-2}-10^{-3}-10^{-4}\right)$ and $0.04 \mathrm{ml}$ of these dilutions were inoculated onto agar plates without and with antibiotics using a spiral plater (Eddy Jet, 
IUL instruments, I.K.S., Leerdam, The Netherlands). The antibiotic concentrations used in the agar plates for both $E$. coli (eosine methylene blue(EMB)-agar, Oxoid CM69, Basingstoke, England) and enterococci (streptococcus KF-agar, Oxoid CM701, Basingstoke, England) were based on NCCLS guidelines and modified (where appropriate) to make comparison with previous studies possible (Table 3 and 4). ${ }^{25,45}$ The prevalence of antibiotic resistance was defined as the number of faecal samples with resistant $E$. coli or enterococci divided by the total number of samples tested multiplied by 100 . The degree of resistance of each sample was defined as the ratio (in $\%$ ) between the number of colonies grown on the agar plates with and without antibiotics. A ratio $\geq 50 \%$ was defined as a high degree of resistance. ${ }^{23}$

\section{Statistical analysis}

The chi-square test was used to analyse the differences in the prevalence and high degree of resistance between the cities Weert \& Roermond, Rotterdam and Groningen in 1999.

\section{RESULTS}

\section{Regional data}

In 1999 the population density of the cities Weert \& Roermond (south), Rotterdam (west) and Groningen (north) was $626 \mathrm{inh} . / \mathrm{km}^{2}, 1946 \mathrm{inh} . / \mathrm{km}^{2}$ and $2046 \mathrm{inh} . / \mathrm{km}^{2}$ respectively. The percentage of citizens in the age-groups 0 -14 years $(17 \%, 17 \%$, $13 \%$ ) 15-64 years $(66 \%, 67 \%, 74 \%)$, and more than 65 years $(17 \%, 16 \%, 13 \%)$ was comparable for the three communities. Furthermore, no clear differences were found in the number of citizens with a full-time income, which comprised $65 \%, 66 \%$ and $64 \%$ of the total population respectively, $4 \%, 10 \%$ and $7 \%$ respectively were unemployed and $15 \%, 17 \%$ and $14 \%$ respectively were retired. 
TABLE 1. Regional antibiotic use in the cities Weert \& Roermond, Rotterdam, and

Groningen in DDD per 1000 inhabitants per day (DID) in 1999.

\begin{tabular}{|c|c|c|c|}
\hline Antibiotic groups & Weert/Roermond & Rotterdam & Groningen \\
\hline Aminopenicillins * & 2.49 & 2.08 & 1.36 \\
\hline Other penicillins ${ }^{b}$ & 2.30 & 2.10 & 0.82 \\
\hline Cephalosporins & 0.04 & 0.09 & 0.09 \\
\hline Tetracyclines & 2.95 & 2.29 & 2.30 \\
\hline Trimethoprim ${ }^{c}$ & 0.78 & 0.83 & 0.81 \\
\hline Nitrofurantoin & 0.87 & 0.59 & 0.57 \\
\hline Fluoroquinolones & 0.75 & 0.97 & 0.39 \\
\hline Nalidixic acid & 0.01 & 0.09 & 0.16 \\
\hline Macrolides & 1.01 & 1.77 & 0.65 \\
\hline Lincosamides & 0.04 & 0.04 & 0.01 \\
\hline Total & 11.24 & 10.85 & 7.16 \\
\hline
\end{tabular}
a) Penicillins with extended spectrum
b) B-lactamase sensitive penicillins, B-lactamase resistant penicillins, Combinations of penicillins, including B-lactamase inhibitors.
c) trimethoprim and combinations of sulfonamides and trimethoprim

The antibiotic consumption in the cities Weert \& Roermond (11.24 DID), Rotterdam (10.85 DID) and Groningen (7.16 DID) in 1999 are shown in Table 1. In general, aminopenicillins, other penicillins and tetracyclines were mainly prescribed. Groningen clearly showed the lowest consumption of antibiotics, especially for the aminopenicillins (1.36 DID), other penicillins (0.82 DID), fluoroquinolones ( 0.39 DID) and macrolides (0.65 DID). In Rotterdam the use of macrolides (1.77 DID) was high (Table 1).

\section{Study population}

171 Faecal samples were collected from participants living in Weert \& Roermond, 133 samples in Rotterdam and 134 samples in Groningen. The response rate ranged from $22 \%$ to $29 \%$. The mean age of the populations analysed was 61 (standard deviation $(\mathrm{SD})=15) 61(\mathrm{SD}=17)$ and $55(\mathrm{SD}=18)$ years respectively. Thirty-five $(20 \%), 16$ $(12 \%)$ and $9(7 \%)$ of the participants living in Weert \& Roermond, Rotterdam and 
Groningen respectively, had used antibiotics in the three months preceding sample collection. The antibiotics used are depicted in Table 2. The highest antibiotic use (n $=42$ ) was found in Weert \& Roermond where amoxicillin $(n=13)$ and doxycycline ( $=8$ ) were mainly prescribed. In the same region, 12 participants were hospitalised in the three months preceding sample collection, whereas no participants from Rotterdam or Groningen had been hospitalised.

TABLE 2. Antibiotic use and hospitalisation in the 3 months prior to sample collection.

\begin{tabular}{lllc}
\hline & Weert \& Roermond & Rotterdam & Groningen \\
\hline Participants /faecal samples (n): & 171 & 133 & 129 \\
Participants that were hospitalised $(\mathrm{n}):$ & 12 & 0 & 0 \\
Participants that used antibiotics $(\mathrm{n}):$ & 35 & 16 & 9 \\
\multicolumn{1}{c}{ Antibiotics used: } & & & \\
Amoxicillin & 13 & 4 & 0 \\
Penicillin & 0 & 2 & 1 \\
Doxycyclin & 8 & 3 & 1 \\
Macrolides & 2 & 3 & 1 \\
Trimethoprim & 2 & 1 & 1 \\
Co-trimoxazol & 0 & 2 & 1 \\
Nitrofurantoin & 0 & 0 & 3 \\
Ciprofloxacin & 2 & 0 & 0 \\
Neomycin & 0 & 0 & 1 \\
Unknown & 8 & 1 & 0 \\
\hline
\end{tabular}

\section{Prevalence of antibiotic resistance}

No significant differences in the prevalence and high degree of resistant E. coli or enterococci were found between the three regions (Table 3 and 4). For E. coli, the highest resistance prevalences and the highest degrees of resistance were observed for amoxicillin, oxytetracycline and trimethoprim (Table 3). The prevalence of ciprofloxacin resistant E. coli was found highest in Weert \& Roermond (2\%), whereas no resistance against this agent was found in Rotterdam or Groningen. Also the resistance prevalence of nalidixic acid was found highest in Weert \& Roermond $(4 \%)$ 
(Table 3). The prevalence of erythromycin $(38 \%)$ and oxytetracycline $(47 \%)$ resistant enterococci in Rotterdam was lower compared to the other regions. In all three regions vancomycin resistant enterococci were isolated at a frequency of 5-6\% (Table4).

\section{DISCUSSION}

In the present study, regional differences in antibiotic consumption were observed. The markedly lower antibiotic use in Groningen (7.16 DID) -especially for aminopenicillins, other penicillins, fluoroquinolones and macrolides- compared to Weert/Roermond (11.19 DID) and Rotterdam (10.84 DID) was difficult to explain. The low use of antibiotics in the city of Groningen, -the capital of the province of Groningen- was in contrast to the results of Baart et al. who described the highest use of antibiotics in the provinces Groningen, Drenthe and Limburg (10-11 DID). 'These data suggest that the antibiotic policy in the city of Groningen is more restrictive than in the surrounding region, as in both studies the information on the antibiotic consumption were obtained from SFK.

The use of macrolides in Rotterdam (1.77 DID) was distinctly higher compared to that of Groningen or Weert \& Roermond. Together with penicillins and tetracyclines, macrolides are often used for respiratory tract infections. ${ }^{1}$ Although in the Netherlands macrolide resistance of Streptococcus pneumonia - the most frequently isolated respiratory tract pathogen - is still low $(4 \%),{ }^{42}$ the high use of macrolides in other European countries like Spain, Italy, Belgium, France and Finland has resulted in high prevalences of resistance to these agents $(24 \%-53 \%){ }^{10,}{ }^{39}$ In the present study, no effect of the relatively high macrolide consumption on the prevalence of erythromycin resistant enterococci in Rotterdam was found yet. However, based on the experiences in other countries prudent use remains warranted. ${ }^{39}$

Although nitrofurantoin and trimethoprim are the preferred antibiotics for acute uncomplicated urinary tract infections, as recommended by the Dutch College of General Practitioners, a substantial amount of fluoroquinolones were used in all three regions, being the highest in Rotterdam $(0.97$ DID). However, no ciprofloxacin resistant $E$. coli were found in Rotterdam or Groningen, whereas the prevalence was 
two percent in Weert \& Roermond. This percentage is still low, but resistance to nalidixic acid, the prototype of quinolones, was also high $(4 \%)$ in Weert \& Roermond and could be used as a sensitive marker for emergence of resistance to fluoroquinolones.

TABLE 3. Prevalence (Prev.) and high degree (HD) of antibiotic resistance (\%) of faecal Escherichia coli.

\begin{tabular}{llllllll}
\hline \hline & & \multicolumn{2}{l}{ Weert \& Roermond } & \multicolumn{2}{l}{ Rotterdam } & \multicolumn{2}{c}{ Groningen } \\
\cline { 3 - 9 } Antibiotic, breakpoint (conc. mg/L) & Prev. & HD & Prev. HD & \multicolumn{2}{l}{ Prev. } & HD \\
\hline Amoxicillin & $(25)$ & 32 & 12 & 30 & 11 & 30 & 12 \\
Cefazolin & $(32)$ & 9 & 1 & 7 & 0 & 11 & 1 \\
Nalidixic acid & $(32)$ & 4 & 1 & 0 & 0 & 2 & 0 \\
Ciprofloxacin & $(4)$ & 2 & 1 & 0 & 0 & 0 & 0 \\
Chloramphenicol & $(4)$ & 9 & 4 & 8 & 1 & 6 & 2 \\
Gentamicin & $(16)$ & 1 & 1 & 1 & 1 & 1 & 0 \\
Nitrofurantoin & $(50)$ & 0 & 0 & 0 & 0 & 0 & 0 \\
Oxytetracycline & $(25)$ & 33 & 11 & 28 & 11 & 33 & 10 \\
Trimethoprim & $(8)$ & 22 & 9 & 19 & 6 & 23 & 9 \\
\hline
\end{tabular}

In spite of the regional differences in antibiotic consumption, no significant differences in the prevalence of antibiotic resistance in both $E$. coli and enterococci were found between the three regions. These results are in contrast with two previously performed studies in the Netherlands that showed regional differences in the antibiotic resistance of $E$. coli isolates from urinary tract infections obtained from general practitioners in the Netherlands. ${ }^{34,42}$ Even though the relation between antibiotic use and antibiotic resistance has been generally accepted, a direct quantitative relationship between the amount of antibiotic used and the frequency of resistance is still lacking. ${ }^{22}$ Several factors might explain this lack of a direct relationship. First larger differences in antibiotic consumption might be needed to find a significant difference in antibiotic resistance. The more than four-fold higher sales of antibiotics in France, Spain and 
Portugal compared to the Netherlands, Denmark, Sweden and Germany ${ }^{5}$ do indeed result in significant differences in antibiotic resistance. ${ }^{4}$

TABLE 4. Prevalence (Prev.) and high degree (HD) of antibiotic resistance (\%) of faecal enterococci.

\begin{tabular}{llllllll}
\hline & & \multicolumn{2}{c}{ Weert \& Roermond } & \multicolumn{2}{c}{ Rotterdam } & \multicolumn{2}{c}{ Groningen } \\
\cline { 3 - 8 } Antibiotic, breakpoint (conc. mg/L) & Prev. & HD & Prev. HD & \multicolumn{2}{c}{ Prev. HD } \\
\hline Amoxicillin & $(25)$ & 0 & 0 & 1 & 1 & 1 & 1 \\
Ciprofloxacin & $(4)$ & 1 & 0 & 0 & 0 & 0 & 0 \\
Erythromycin & $(10)$ & 47 & 8 & 38 & 8 & 47 & 4 \\
Gentamicin & $(500)$ & 4 & 1 & 5 & 1 & 5 & 1 \\
Oxytetracycline & $(25)$ & 58 & 15 & 47 & 9 & 57 & 12 \\
Vancomycin & $(10)$ & 6 & 0 & 5 & 1 & 5 & 0 \\
\hline
\end{tabular}

Second, historical data on antibiotic use are probably more important than current data to explain the prevalence of antibiotic resistance. However, the antibiotic use in the Netherlands, outside the hospitals was more or less constant in the past four years.' Third the data were analysed on a group level perspective and do not link individual outcome events to individual exposure histories. ${ }^{13,14}$ In the present study on regional level, antibiotic use was comparable for Weert \& Roermond and Rotterdam, but a higher number of participants $(20 \%)$ Weert \& Roermond used antibiotics compared to Rotterdam (12\%). Also the number of hospitalised participants was higher $(n=12)$ in Weert \& Roermond, which could have influenced the antibiotic resistance data in this region. However, the participants $(n=42)$ that used antibiotics and or were hospitalised in the three months prior sample collection, showed no significant higher resistance prevalences (data not shown) compared to their regional counterparts that did not.

Fourth, next to the use of antibiotics in human medicine a large amount of antibiotics is used in veterinary medicine, as therapy or feed additives. Approximately $50 \%$ of all antibacterial agents used yearly in the European Union (EU), ${ }^{47}$ and more than $80 \%$ in the USA are given to animals, ${ }^{31}$ causing resistance in their enteric bacteria such as $E$. 
coli and enterococci. These resistant bacteria and/or their resistance genes can be transferred from animals to humans via the food chain. ${ }^{18}$ As no difference in the exposure of resistant enteric bacteria from bacteria is expected between regions, the influence of antibiotic use is veterinary medicine on humans is comparable.

Finally, besides the use of antibiotics, the potential of antibiotic resistant bacteria and resistance genes to disseminate is another very important factor for the prevalence of antibiotic resistance. With the increase in population in the Netherlands, population density and urbanisation increased as well facilitating the spread of resistant bacteria and resistance genes. ${ }^{8,26,35,36}$ Although the population density in Weert \& Roermond was markedly lower than in Rotterdam or Groningen no significant differences in resistance prevalence were found.

In conclusion, the present study showed no significant regional differences in antibiotic resistance among the commensal bacteria $E$. coli and enterococci. However, the observed differences in antibiotic consumption could lead to changes in antibiotic resistance in the future. Surveillance of antibiotic use and antibiotic resistance is strongly recommended to control the development of antibiotic resistance as it provides epidemiological data to set up and control antibiotic guidelines.

\section{ACKNOWLEDGEMENTS}

This investigation was supported financially by ZorgOnderzoek Nederland (ZON), The Netherlands [97-1-104]. We thank C. Driessen, Dr. N. London and M. Schneiderberg for their expert technical assistance. 


\section{REFERENCES}

1. Baart, F., and A.J. de Neeling. 2001. Antibioticagebruik buiten het ziekenhuis. Pharmaceutisch Weekblad 22: 786-790.

2. Bax, R., R. Bywater, G. Cornaglia, H. Goossens, P. Hunter, V. Isham, V. Jarlier, R. Jones, I. Phillips, D. Sahm, S. Senn, M. Struelens, D. Taylor, and A. White. 2001. Surveillance of antimicrobial resistance - what, how and whither? Clin. Microbiol. Infect. 7: 316-325.

3. Bradley, S.J., A.L. Wilson, M.C. Allen, H.A. Sher, A.H. Goldstone, and G.M. Scott. 1999. The control of hyperendemic glycopeptide-resistant Enterococcus spp on a haematology unit by changing antibiotic usage. J. Antimicrob. Chemother. 43: 261-6.

4. Buchholz, U., S. Bronzwaer, W. Goettsch, J. Monen, J. Kool, J. Degener, and EARSS participants. 2001. New results from the European Antimicrobial Resistance Surveillance System (EARSS): implications for intervention efforts. IIth European Congress of Clinical Microbiology and Infectious Diseases, 1- 4 April 2001, Istanbul, Turkey,

5. Cars, O. 2001.Variation in antibiotic use in the European Union. Lancet 357: 1851-1853.

6. Cizman, M., M. Pokorn, K. Seme, A. Orazem, and M. Paragi. 2001.Correlation between increased consumption of fluoroquinolones in outpatients and resistance of Escherichia coli from urinary tract infections. J. Antimicrob. Chemother. 47: 495-502.

7. Dominguez, E.A., T.L Smith, E. Reed, C.C Sanders, and W.E. Sanders. 2000. A pilot study of antibiotic cycling in a hematology-oncology unit. Infect. Contr. Hosp. Epidemiol. 21 (Suppl 1): 4-8.

8. Ehresmann, K.R., C.W. Hedberg, M.B. Grimm, C.A. Norton, K.L. MacDonald, and M.T. Osterholm. 1995. An outbreak of measles at an international sporting event with airborne transmission in a domed stadium. J. Infect. Dis. 171: 679-83.

9. Enne, V.I., D.M. Livermore, P. Srephens, and L.M.C. Hall. 2001. Persistence of sulphonamide resistance in Escherichia coli in the UK despite national prescribing restriction. Lancet 357: $1325-$ 1328.

10. Fitoussi, F., C. Doit, P. Geslin, N. Brahimi, and E. Bingen. 2001. Mechanisms of macrolide resistance in clinical pneumococcal isolates in France. Antimicrob. Agents Chemother. 45: 636-8.

11. Gaynes, R, and D. Monnet. 1997. The contribution of antibiotic use on the frequency of antibiotic resistance in hospitals. Ciba Found. Symp. 207: 47-56; discussion 56-60.

12. Gillespie, S.H. 2001. Antibiotic resistance in the absence of selective pressure. Int. J. Antimicrob. Agents 17: 171-176.

13. Greenland, S. 1992. Divergent biases in ecologic and individual-level studies. Stat. Med. 11: 120923.

14. Harbarth, S., A.D. Harris, Y. Carmeli, and M.H. Samore. 2002. Parallel analysis of individual and aggregate data on antibiotic exposure and resistance in gram-negative bacilli. Clin. Infect. Dis. 33: 1462-68. 
15. Hoogkamp-Korstanje, J. 2001. Antibioticresistentie; een advies van de raad voor gezondheidsonderzoek. Ned. Tijdschr. Geneesk. 145: 1192-1193.

16. Howard, A.J., J.T. Magee, K.A. Fitzgerald, and F.D.J Dunstan. 2001. Factors associated with antibiotic resistance in coliform organisms from community urinary tract infection in Wales. J. Antimicrob. Chemother. 47: 305-313.

17. Huovinen, P., Seppala, H., J. Kataja, and T. Klaukka. 1997. The relationship between erythromycin consumption and resistance in Finland. Finnish Study Group for Antimicrobial Resistance. Ciba Found. Symp. 207: 36-41; discussion 41-6.

18. Klare, I., H. Heier, H. Claus, G. Böhme, S. Marin, G. Seltmann, R. Hakenbeck, V. Antanassova, and W. Witte. 1995. Enterococcus faecium strains with vanA-mediated high-level glycopeptide resistance isolated from animal foodstuffs and fecal samples of humans in the community. Microb. Drug Resist. 1:265-272.

19. Kresken, M., D. Hafner, H. Mittermayer, L. Verbist, E. Bergogne-Berezin, H. Giamarellou, S. Esposito, B. van Klingeren, F.H. Kayser, D.S. Reeves, et al. 1994. Prevalence of fluoroquinolone resistance in Europe. Infection 22 (suppl. 2):90-98.

20. Kunin, C.M., H.L Lipton, T. Tupasi, T. Sacks, W.E. Scheckler, A. Jivani, A. Goic, R.R. Martin, R.L. Guerrant, and V. Thamlikitkul. 1987. Social, behavioral, and practical factors affecting antibiotic use worldwide: report of Task Force 4. Rev. Infect. Dis. 9: 270-85.

21. Levy, S.B. 1997. Antibiotic resistance: an ecological imbalance. Ciba Found. Symp. 207: 1-9; discussion 9-14.

22. Levy, S.B. 2001. Antibiotic resistance: consequences of inaction. Clin. Infect. Dis. 33 (Suppl.3): $124-9$.

23. Levy S.B., B. Marshall, S. Schluederberg, D. Rowse, and J. Davis. 1988. High frequency of antimicrobial resistance in human fecal flora. Antimicrob. Agents Chemother. 32: 1801-6.

24. Livermore, D.M., P. Stephens, J. Weinberg, A.P. Johnson, T. Gifford, D. Northcott, D. James, R.C. George, and D.C.E. Speller. 2000. Regional variation in ampicillin and trimethoprim resistance in Escherichia coli in England from 1990 to 1997, in relation to antibacterial prescribing. J. Antimicrob. Chemother. 46: 411-422.

25. London, N., R. Nijsten, A. van den Bogaard, and E. Stobberingh. 1993. Antibiotic resistance of faecal Enterobacteriaceae isolated from healthy volunteers, a 15-week follow-up study. J. Antimicrob. Chemother. 32: 83-91.

26. MacKenzie, W.R., J.J. Kazmierczak, and J.P. Davis. 1995. An outbreak of cryptosporidiosis associated with a resort swimming pool. Epidemiol. Infect. 115: 545-53.

27. Magee, J.T., E.L. Pritchard, K.A. Fitzgerald, F.D.J. Dunstan, and A.J. Howard. 1999. Antibiotic prescribing and antibiotic resistance in community practice: retrospective study, 1996-8. Brit. Med. J 319: 1239-1240. 
28. Masterton, R.G. 2000. Surveillance studies: how can they help the management of infection? J Antimicrob. Chemother. 46 (Suppl. T2): 53-58.

29. McGowan, J.E. 1994. Do intensive hospital antibiotic control programs prevent the spread of antibiotic resistance? Infect. Contr. Hosp. Epidemiol. 15: 478-83.

30. McGowan, J.E. 1999. Drug resistance and nosocomial infections: epidemiology and prevention strategies. Clin. Infect. Dis. 5: 177-192.

31. Mellon, M., Benbrook, C., and Benbrook, K.L. 2001. Hogging it: Estimates of Antimicrobial Abuse in Livestock. Union of concerned scientists.

32. Nissinen, A, P. Gronroos, P. Huovinen, E. Herva, M.L. Katila, T. Klaukka, S. Kontiainen, O. Liimatainen, S. Oinonen, and P.H. Makela. 1995. Development of beta-lactamase-mediated resistance to penicillin in middle-ear isolates of Moraxella catarrhalis in Finnish children, 1978-1993. Clin. Infect. Dis. 21: 1193-6.

33. Okeke, I.N., A. Lamikanra, and R. Edelman. 1999. Socioeconomic and behavioral factors leading to acquired bacterial resistance to antibiotics in developing countries. Emerg. Infect. Dis. 5: 18-27.

34. Overbeek, B, C.J. Overdijk, J.H.W. Dikhoff, and W.G. Goetsch. 2001. Goede gevoeligheid van Escherichia coli voor antimicrobiele middelen gebruikt voor de behandeling van urineweginfecties in de eerste lijn; resultaten van een fecesonderzoek onder gezonde personen in Friesland. Ned. Tijdschr. Geneesk. 145: 688-691.

35. Papapetropoulou, M., and A.C. Vantarakis. 1998. Detection of adenovirus outbreak at a municipal swimming pool by nested PCR amplification. J. Infect. 36: 101-3.

36. Raffalli, J., K.A. Sepkowitz, and D. Armstrong. 1996. Community-based outbreaks of tuberculosis. Arch. Intern. Med. 156: 1053-60.

37. Reservoirs of Antibiotic Resistance Networks (ROAR). 1998. Commensal Bacteria- an important reservoir for antibiotic resistance genes? www.healthsci.tufts.edu.

38. Sattar, S.A., J. Tetro, and V.S. Springthorpe. 1999. Impact of changing societal trends on the spread of infections in American and Canadian homes. Am. J. Inf. Control 27: (Suppl.) 4-21.

39. Seppala, H., T. Klaukka, J. Vuopio Varkila, A. Muotiala, H. Helenius, K. Lager, and P. Huovinen. 1997. The effect of changes in the consumption of macrolide antibiotics on erythromycin resistance in group A streptococci in Finland. Finnish Study Group for Antimicrobial Resistance. N. Engl. J. Med. 337: 441-6.

40. Shanahan, P.M., C.J. Thomson, and S.G. Amyes. 1995. Beta-lactam resistance in normal faecal flora from South Africa. Epidemiol. Infect. 115: 243-53.

41. Sorensen, T.L., and D. Monnet. 2000. Control of antibiotic use in the community: The Danish experience. Infect. Control Hosp.Epidem. 21: 387-389.

42. Stobberingh, E.E., A.J. de Neeling, and C.F.H. Rosmalen. 2001. The more you use it, the more you lose it. Pharmaceutisch Weekblad 22: 804-808. 
43. Struelens, M.J.1998. The epidemiology of antimicrobial resistance in hospital acquired infections: problems and possible solutions. Brit. Med. J. 317: 652-654.

44. Thomson, C.J., P.M. Shanahan, and S.G. Amyes. 1994. TEM-1 plasmids in the community. Lancet 343: 921.

45. Van den Bogaard, A.E, N. London, C. Driessen, and E.E. Stobberingh. 2001. Antibiotic resistance of faecal Escherichia coli in poultry, poultry farmers and poultry slaughterers. J. Antimicrob. Chemother. 47: 763-771, 2001.

46. Van den Bogaard, A.E., and E.E. Stobberingh. 1999. Contamination of animal feed by multiresistant enterococci. Lancet 354: 163.

47. Van den Bogaard, A. E., and E. E. Stobberingh. 1999. Antibiotic use in animals: impact on bacterial resistance and public health. Drugs 58:589-607.

48. Vatopoulos, A.C. 1998. High rates of antibiotic resistance among normal fecal flora Escherichia coli isolates in children from Greece. Clin. Microbiol. Infect. 4: 563-569. 


\section{CHAPTER 4}

\section{The Influence of Population Density on Antibiotic}

\section{Resistance}

N. Bruinsma ${ }^{a}$, J M. Hutchinson ${ }^{b}$, A. E. van den Bogaard ${ }^{a}$, H. Giamarellou ${ }^{c}$, J.

Degener $^{d}$ and E. E. Stobberingh ${ }^{a}$

a'Department Medical Microbiology, University Maastricht, P.O. Box 5800, $6202 \mathrm{AZ}$

Maastricht, The Netherlands;

${ }^{b}$ Discipline of Laboratory Medicine (Medical Microbiology), Faculty of Medicine, Memorial University of Newfoundland, Canada;

${ }^{c} 4$ th Department of Internal Medicine, University of Athens, Greece;

${ }^{d}$ Department Medical Microbiology, University Hospital Groningen, P.O. Box 30001, 9700

RB Groningen, The Netherlands.

Journal of Antimicrobial Chemotherapy: accepted pending minor revisions 


\begin{abstract}
Antibiotic consumption and population density as a measure of crowding in the community were related to the prevalence of antibiotic resistance of three cities in three different countries: St. Johns in Newfoundland (Canada), Athens in Greece and Groningen in The Netherlands. Antibiotic consumption was expressed in DDD (defined daily dose), as DID (= DDD per 1000 inhabitants per day) and as DSD (= DDD per square kilometer). The prevalence of antibiotic resistant $E$. coli and enterococci was determined in faecal samples of healthy volunteers. In both Newfoundland and Greece the overall consumption of antibiotics (28 DID) was more than three times higher compared to that of the Netherlands (9 DID). The lowest prevalence of resistant $E$. coli against the majority of antibiotics tested was found for the samples from Newfoundland and was significant $(p<0.05)$ for cefazolin, oxytetracyline, and trimethoprim. A poor correlation between the number of DID and the prevalence of resistance was observed (the Pearson correlation coefficient (Pcc) ranged between -0.93 and 0.87 ). However, when population density was taken into consideration and antibiotic consumption was expressed in DSD, a strong correlation was found (and Pcc ranged between 0.86 and 1.00). This study suggests that population density is an important factor in the development of antibiotic resistance, and warrants special attention as a factor in resistance epidemiology.
\end{abstract}




\section{INTRODUCTION}

Several studies have found a positive association between antibiotic use and antibiotic resistance in the community. ${ }^{1-4}$ However, this is not a direct relationship and therefore other factors must contribute to the degree of antibiotic resistance observed in a population. 5,6

Besides selection pressure (antibiotic use), dissemination of resistant bacteria and resistance genes among individuals increase further the extend of prevalence of antibiotic resistance in a population. ${ }^{7}$ Migration of people and increase in population density through urbanisation set up many opportunities for interpersonal contact facilitating the spread of resistant bacteria and resistance genes, ${ }^{8}$ and may be an important factor in the dissemination of antibiotic resistance. So is it well recognised that dissemination of antibiotic resistant micro-organisms from patient to patient directly, via instruments or via health care workers, is an important cause of hospital acquired infections, ${ }^{9}$ but it facilitates also the transmission of resistant bacteria and genes. Analogous to the hospital situation where patients live closely together in a relatively small area, population density may be considered a crowding factor outside the hospital.

In the present study antibiotic consumption and population density were related to the prevalence of antibiotic resistant faecal Escherichia coli and enterococci of healthy volunteers living in three cities from three different countries i.e. Canada, Greece, and the Netherlands. E. coli and enterococci were used as indicator bacteria, because they represent species of the main facultativily aerobic intestinal flora in humans. ${ }^{10-12}$

Part of the study was presented as a poster at the 40th Interscience Conference on Antimicrobial Agents and Chemotherapy, Toronto, Ontario, Canada, September 1720, 2000 (abstract 101). 


\section{MATERIALS AND METHODS}

\section{Demographic data}

The population density of the cities St. Johns (Newfoundland, Canada), Athens (Greece) and Groningen (The Netherlands) was measured using official published information from the respective governmental authorities. Antibiotic consumption was for Newfoundland obtained from IMS Health. Antibiotic consumption in Greece was derived from Pharmetrica S.A., a subsidiary of the National Drug Organization of Greece. The over-the-counter use of antibiotics in Greece was included in the amounts measured. Antibiotic use in the Netherlands was obtained from the Scientific Institute of Dutch Pharmacists (SFK). Antibiotic consumption in the community was calculated for the province of Newfoundland in 1998 and for the countries, Greece and The Netherlands in 1999. The total consumption included the following classes of antibiotics: penicillins, cephalosporins, macrolides/lincosamides, tetracyclines, trimethoprim/sulfonamides and fluoroquinolones (Table 1).

Antibiotic use was expressed as the number of defined daily dose (DDD) consumed per 1000 inhabitants per day (DID) and as the number of DDD consumed per square kilometre $\left(\mathrm{km}^{2}\right)$ per day (DSD). The number of DID multiplied by the population density (the number of inhabitants per $\mathrm{km}^{2}$ ) is the number of DDD per $\mathrm{km}^{2}$ per day.

\section{Study population}

Faecal samples from residents of the cities St. Johns (NFL), Athens (GR) and Groningen (NL) were obtained using randomly selected addresses from the telephone directory. In each city 600 residents were addressed, expecting a response of approximately $30 \%$. The countries and respective cities were chosen because of their variety in antibiotic use and population density. Requests with sample bottles were post delivered to the addresses with a letter stating the purpose of the study. 


\section{Culture methods}

The participants were asked to mail or bring their sample on the day of collection to a local laboratory where two grams of each sample were diluted $1: 10$ in $0.9 \%(\mathrm{w} / \mathrm{v})$ $\mathrm{NaCl}$ supplemented with $20 \%(\mathrm{v} / \mathrm{v})$ glycerol. The participants of Groningen send their sample directly to the microbiological laboratory of the University Hospital Maastricht.

The diluted samples were stored at $-20^{\circ} \mathrm{C}$ in the local laboratories and subsequently those of St. Johns and Athens were transported on dry ice to the microbiological laboratory of the University Hospital Maastricht.

All further microbiological processing was done in Maastricht as described previously. ${ }^{13}$ In short, after thawing the samples were further diluted. For E. coli, 40 $\mu \mathrm{L}$ of $10^{-2}$ and $10^{-4}$ in $0.9 \%$ saline were inoculated on Levine agar plates (EMBeosine methylene blue agar, Oxoid CM69, Basingstoke, England) with and without antibiotics using a spiral plater (Eddy Jet, IUL instruments, I.K.S., Leerdam, The Netherlands). For enterococci, KF-Streptococcus agar plates (Oxoid CM701, Basingstoke, England) were inoculated with $40 \mu \mathrm{L}$ of $10^{-1}$ and $10^{-3}$ dilutions with and without antibiotics. The antibiotic concentrations used in the agar plates for both $E$. coli and enterococci were based on NCCLS guidelines, and are presented in Tables 2 and 3 for $E$. coli and enterococci respectively. E. coli grows on Levine agar as purple colonies with a black centre and metallic shine. Only these colonies were counted after 18-24 hours incubation at $37^{\circ} \mathrm{C}$. For identification a colony was randomly picked from the agar plate and were tested for indole and $\beta$-glucuronidase reaction. Previous studies have shown that $E$. coli isolates had identical or higher MICs than the antibiotic concentration of the selective plate they were isolated from. ${ }^{13-15}$ Enterococci appear as typical red or pink colonies on KF-Streptococcus agar. After $48 \mathrm{~h}$ incubation at $42^{\circ} \mathrm{C}$ only the typical pink colonies were counted. The randomly picked enterococci colonies were identified by using tolerance to bile, esculin hydrolysis, growth in $6.5 \%$ (wt/vol) $\mathrm{NaCl}$, and a positive pyrrolidonylarylamidase reaction (Wellcome). A previous study has shown that enterococci isolates had identical or higher MICs than the antibiotic concentration of the agar plate they were selected from ${ }^{16}$ 
The prevalence (\%) of antibiotic resistance was defined as the number of faecal samples showing growth of resistant $E$. coli or enterococci divided by the total number of faecal samples tested multiplied by 100 . The degree of resistance of each sample was defined as the ratio (in \%) between the number of colonies grown on the agar plates with and without antibiotics.

The study was approved by the Medical Ethical Committee of the University Hospital Maastricht (no. 97-1-104).

\section{Statistical analysis.}

The chi-square test was used to determine the significant differences $(\mathrm{p} \leq 0.05,2$ sided) in the prevalence of antibiotic resistance between the three different populations. For a valid chi-square test all expected frequencies had to be $\geq$ one and no more than $20 \%$ of the expected frequencies may be less than $5 .^{17}$ If the data did not fulfil these criteria the significant differences were invalid and therefore not tested. Pearson's coefficient of correlation (Pcc) was used to assess the correlation between antibiotic consumption - expressed by the number of defined daily dosage (DDD) per 1000 inhabitants per day (DID) and the number of DDD consumed per square kilometer per day (DSD) - and antibiotic resistance between the three populations. All analyses were performed in SPSS for Windows.

\section{RESULTS}

\section{Demographic data}

The population densities of the cities St. Johns, Athens and Groningen were 255 $\left(127,482\right.$ inhabitants $\left./ 499 \mathrm{~km}^{2}\right), 8,194\left(3,523,407 \mathrm{inh} . / 3,351 \mathrm{~km}^{2}\right)$ and 2,046 (171,193 inh. $/ 84 \mathrm{~km}^{2}$ ) inhabitants $/ \mathrm{km}^{2}$ respectively. The population density of Athens was 4 times higher than Groningen and 32 times higher than St. Johns. 


\section{Study population}

Faecal samples were obtained from 154, 179 and 129 residents from St. Johns, Athens and Groningen, with a response rate of $26 \%, 30 \%$, and $29 \%$ respectively. The mean age (standard deviation) of the participants was 55(15), 47(21), and 55(18) respectively.

\section{Antibiotic use}

As shown in Table 1 the total use of antibiotics in DDD per 1000 inhabitants per day (DID) was 3 times higher for Newfoundland (28 DID) and Greece (28 DID) compared to the Netherlands ( 9 DID), whereas the total observed use in DDD per square kilometer per day (DSD) was the lowest for St. Johns (7) DSD followed by Groningen (19) DSD and by far the highest for Athens (230 DSD).

TABLE 1. Antibiotic use in DDD per 1000 inhabitants per day (DID) and in DDD per square km per day (DSD) for the province Newfoundland (NFL) and the countries Greece (GR) and the Netherlands (NL).

\begin{tabular}{lllllll}
\hline \hline & \multicolumn{2}{l}{ NFL } & \multicolumn{3}{c}{ GR } & \multicolumn{2}{l}{ NL } \\
\cline { 2 - 7 } Antimicrobial agents & DID & DSD & DID & DSD & DID & DSD \\
\hline Aminopenicillins & 11 & 3 & 6 & 52 & 2 & 4 \\
Other penicillins & 3 & 0.7 & 4 & 33 & 2 & 4 \\
Cephalosporins & 4 & 1 & 6 & 49 & 0.1 & 0.2 \\
Macrolides \& Lincosamides & 4 & 0.9 & 7 & 57 & 1 & 3 \\
Trimethoprim & 3 & 0.8 & 0.7 & 5 & 0.8 & 2 \\
Tetracyclines & 1 & 0.4 & 3 & 21 & 2 & 5 \\
Quinolones & 2 & 0.5 & 2 & 12 & 0.8 & 2 \\
\hline Total & 28 & 7 & 29 & 229 & 9 & 20 \\
\hline
\end{tabular}

For all antibiotic groups Athens clearly showed the highest numbers of DSD, and St. Johns the lowest, except for cephalosporins, which was lowest in Groningen $(0.2$ DSD) (Table 1). 


\section{Prevalence of antibiotic resistance}

In general, the prevalence of resistance for $E$. coli and enterococci for almost all agents tested was found highest in Athens, followed by Groningen and was found lowest in St. Johns (Table 2 and 3).

TABLE 2. Prevalence of antibiotic resistance of faecal Escherichia coli.

\begin{tabular}{|c|c|c|c|c|c|c|}
\hline \multirow{2}{*}{$\begin{array}{l}\text { Antibiotic } \\
\text { (conc. mg/L) }\end{array}$} & \multicolumn{3}{|c|}{ Prevalence (\%) } & \multicolumn{3}{|c|}{ P-value } \\
\hline & St. Johns & Athens & Groningen & $\mathrm{S} / \mathrm{A}$ & $\mathrm{A} / \mathrm{G}$ & $\mathrm{S} / \mathrm{G}$ \\
\hline Amoxicillin (25) & 22 & 39 & 30 & 0.00 & 0.11 & 0.09 \\
\hline Cefazolin (32) & 3 & 26 & 11 & 0.00 & 0.00 & 0.00 \\
\hline Nalidixic acid (32) & 1 & 12 & 2 & 0.00 & 0.00 & * \\
\hline Ciprofloxacin(4) & 1 & 3 & 0 & * & * & * \\
\hline Chloramphenicol (4) & 1 & 13 & 6 & 0.00 & 0.06 & * \\
\hline Gentamicin (16) & 1 & 2 & 1 & * & * & $*$ \\
\hline Nitrofurantoin (50) & 0 & 0 & 0 & $*$ & * & $*$ \\
\hline Oxytetracycline (25) & 16 & 50 & 33 & 0.00 & 0.00 & 0.00 \\
\hline Trimethoprim (8) & 10 & 31 & 23 & 0.00 & 0.11 & 0.00 \\
\hline
\end{tabular}

* not tested

E. coli: The prevalence of amoxicillin, chloramphenicol and trimethoprim resistance was significantly higher $(\mathrm{p} \leq 0.05)$ in Athens compared to St. Johns. The resistance prevalence of cefazolin, nalidixic acid, and oxytetracycline was significantly higher ( $p$ $\leq 0.05$ ) in Athens compared to both St. Johns and Groningen. Resistance to cefazolin, trimethoprim, and oxytetracycline was significantly higher in Groningen compared to St. Johns. No nitrofurantoin resistance was observed in the three cities (Table 2).

Enterococci: The prevalence of resistance to ciprofloxacin, erythromycin, and oxytetracycline was significantly higher $(\mathrm{p} \leq 0.05)$ in Athens than in St. Johns and Groningen. In Groningen resistance to erythromycin, and oxytetracycline was significantly higher than in St. Johns (Table 3). 
TABLE 3. Prevalence of antibiotic resistance of faecal enterococci.

\begin{tabular}{|c|c|c|c|c|c|c|}
\hline \multirow[b]{2}{*}{ Antibiotic (conc. mg/L) } & \multicolumn{3}{|c|}{ Prevalence (\%) } & \multicolumn{3}{|c|}{ P-value } \\
\hline & $\underline{\text { St. Johns }}$ & Anthens & Groningen & $\mathrm{S} / \mathrm{A}$ & $\mathrm{A} / \mathrm{G}$ & $\mathrm{S} / \mathrm{G}$ \\
\hline Amoxicillin (25) & 1 & 3 & 1 & $*$ & $*$ & $*$ \\
\hline Ciprofloxacin (4) & 1 & 13 & 0 & 0.00 & 0.00 & $*$ \\
\hline Erythromycin (10) & 12 & 80 & 47 & 0.00 & 0.00 & 0.00 \\
\hline Gentamicin (500) & 2 & 6 & 5 & 0.06 & 0.57 & $*$ \\
\hline Oxytetracycline (25) & 33 & 88 & 57 & 0.00 & 0.00 & 0.00 \\
\hline Vancomycin (10) & 0 & 2 & 5 & $*$ & $*$ & $*$ \\
\hline
\end{tabular}

* not tested

\section{Relation between antibiotic resistance and antibiotic use}

For the majority of antimicrobial agent and resistance combinations in the present study, a better correlation was found when antibiotic consumption was expressed in DSD compared to DID (Table 4). For example, the prevalence of amoxicillin resistant E. coli correlated much better with the number of aminopenicillins in DSD $(\operatorname{Pcc}=0.89)$ than when expressed in DID ( $\mathrm{Pcc}=-0.39)$ (Table 4, Figure 1 and 2 ).

\section{DISCUSSION}

The participation rate (26-30\%) and mean age of participants (47-55 years) was in the same order in all three cities. The low response can be partly explained by the discomfort of sending in a faecal sample. In Newfoundland and Greece the overall consumption of antibiotics (DID) was three times higher compared to that of The Netherlands. However, the lowest prevalence of resistance for the majority of antibiotics tested was found for the samples from Newfoundland. This was significant for cefazolin, oxytetracyline, and trimethoprim resistant $E$. coli and erythromycin and oxytetracycline resistant enterococci.

Antibiotic use is generally considered as the major factor determining the prevalence of antibiotic resistance in a population. Another important factor contributing to the development of antibiotic resistance is the dissemination of resistant bacteria or resistance genes from a resistant donor to a susceptible host, which subsequently can 
either become colonised by these bacteria and/or these bacteria might transfer their resistance genes to bacteria belonging to the intestinal flora of the new host during their passage trough the intestinal tract. In the hospital it is generally accepted that patients either colonised or infected with multiresistant micro-organisms must be isolated to prevent spread of the resistant micro-organisms to other patients. Outside the hospital a higher prevalence of resistance was observed among persons living in close contact with pigs and poultry, which have a very high prevalence and degree of resistance in their intestinal flora due to the excessive use of antimicrobials as growth promoters and therapy in animal husbandry, i.e. farmers, compared to urban residents living in the same geographic region. ${ }^{18}$

TABLE 4. The Pearson correlation between the prevalence of resistance and antibiotic use in DDD per 1000 inhabitants per day (DID) and DDD per $\mathrm{km}^{2}$ per day (DSD) for the different regions.

\begin{tabular}{llll}
\hline & & \multicolumn{2}{c}{ Pearson correlation: } \\
\cline { 3 - 4 } Prevalence E. coli resistance & Antimicrobial agent & DID & DSD \\
\hline Amoxicillin & Aminopenicillin & -0.39 & 0.89 \\
Trimethoprim & Trimethoprim & -0.93 & 0.86 \\
Nalidixic acid & Quinolones & -0.29 & 1.00 \\
Cefazolin & Cephalosporins & 0.64 & 0.93 \\
Oxytetracycline & Tetracyclines & 0.87 & 0.98 \\
\hline Prevalence enterococci resistance & Antimicrobial agent & DID & DSD \\
\hline Erythromycin & Macrolides & 0.60 & 0.87 \\
Oxytetracycline & Tetracyclines & 0.87 & 0.98 \\
\hline
\end{tabular}

This clearly shows that living in an environment with resistant bacteria is a real risk for acquiring such bacteria and that the closer the contact the larger the risk. Similar to the hospital environment and living in close contact with food animals one could speculate that in the community living in close contact with other persons harbouring resistant micro-organisms or resistant genes is a risk factor to acquire antibiotic resistance. The commonly observed high levels of resistance among intestinal 
colonisers and clinical isolates in the developing world support cross infection in this case not only from crowding but mainly from poor sanitation as an important means of sharing resistant bacteria in many parts of the world. ${ }^{12,19}$ However, it seems unlikely that in this study differences in hygienic standards have influenced significantly the prevalence of resistance, since Canada, the Netherlands and Greece are all developed countries with high and similar sanitation standards.

The results of this study indicate that next to antibiotic consumption population density is a factor influencing the prevalence of antibiotic resistance in the faecal flora of healthy individuals in populations. Using population density -as a measure of crowding in the community- we found a good correlation between the number of DSD and the prevalence of resistance for the majority of antibiotics. In contrast even negative Pearson correlation coefficients were found for the consumption expressed in DID of these agents and the prevalence of resistance. This suggests that the chance for a susceptible host to pick up resistant bacteria or resistance genes from a resistant neighbour is higher in areas with a high population density (like Groningen and Athens), than in areas with a low population density like St. Johns. Antibiotics are social drugs but they can only socialise if (susceptible) hosts are in the neighbourhood. In an area with high antibiotic use by several persons living far apart from each other (St. Johns) the contribution of the transfer/spread of resistant bacteria to a susceptible host are lower than in an area where people live next/close to each other.

Not for all drug-resistance combinations a better correlation was found when the prevalence of resistance was related to DSD instead of DID. Comparable Pcc's were observed for oxytetracycline and macrolides. This could be explained by the existing high prevalence of resistance of these agents both in Athens and Groningen. Also the ability of resistance mechanisms to spread can differ, and easy moving genes might need less population density to disseminate. In the present study however, no molecular analysis were performed to detect the actual resistance mechanisms of the isolated organisms. 


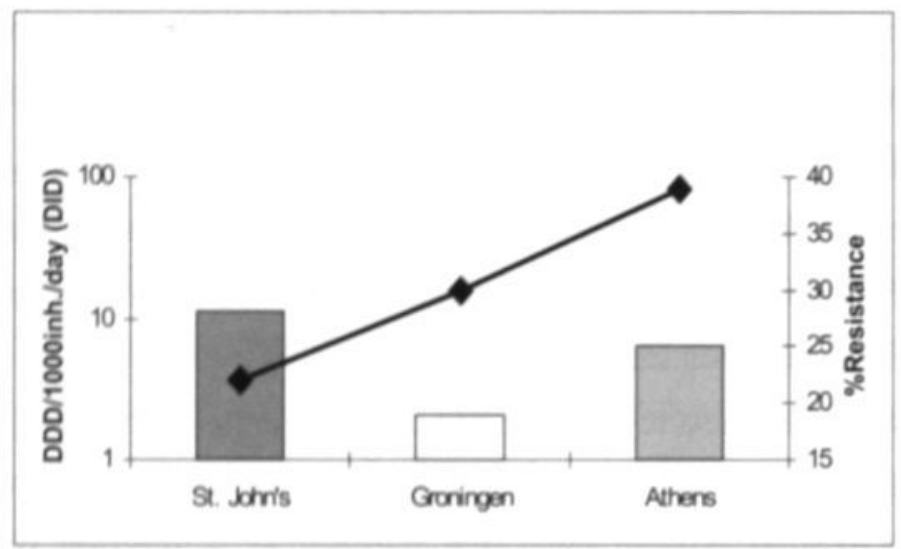

FIGURE 1. The prevalence of amoxicillin resistant $E$. coli $(\bullet)$ against aminopenicillin consumption in DDD/1000 inhabitants/day (DID).

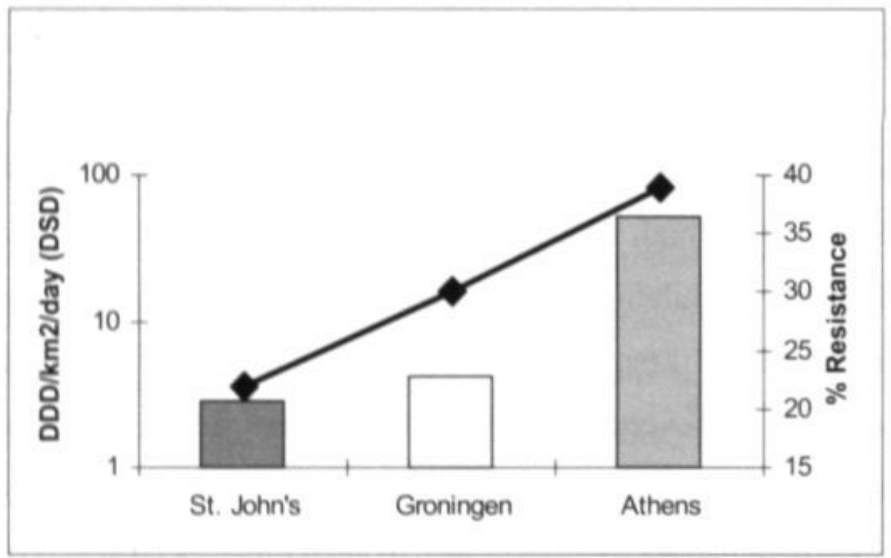

FIGURE 2. The prevalence of amoxicillin resistant $E$. coli $(\bullet)$ against aminopenicillin consumption in DDD/ $\mathrm{km}^{2} /$ day (DSD).

In our attempt to point out the importance of crowding in the community as a factor to facilitate dissemination of resistant bacteria to susceptible hosts and resistance genes, we recognise that this study has several limitations. Only 3 places were involved and surely other factors play a role in the development of resistance besides antibiotic use and population density. For instance the warmer climate in Athens compared to St. Johns and Groningen, promotes the growth of (resistant) enteric bacteria in the environment. Apart from human antibiotic consumption the differences in the amount and kind of antibiotics used in animal husbandry or for crop protection also might have influenced the prevalence of resistance in the three populations. Moreover the 
correlation between antibiotic resistance and the use of a specific antibiotic agent or group could have been biased by multiple- or cross-resistance, as the use of one agent can maintain high levels of resistance to another. However, due to the magnitude of the differences in antibiotic use, population density and antibiotic resistance between the 3 places we do not expect that, for example the relatively low response rate, or the fact that antibiotic use was measured on a country/provincial basis and not regional, could substantially have influenced the study outcome.

In conclusion this study implies that population density, as a measure of crowding might be an important actor in the prevalence of antibiotic resistance in populations and warrants special attention in resistance epidemiology. 


\section{REFERENCES}

1. Arason, V. A., Kristinsson, K. G., Sigurdsson, J. A., Stefansdottir, G., Molstad, S. \& Gudmundsson, S. (1996). Do antimicrobials increase the carriage rate of penicillin resistant pneumococci in children? Cross sectional prevalence study. British Medical Journal 313, 387-91.

2. Baquero, F. (1996) Antibiotic resistance in Spain: What can be done? Clinical Infectious Diseases 23, 819-23.

3. Seppala, H., Klaukka, T., Vuopio Varkila, J., Muotiala, A., Helenius, H., Lager, K. \& Huovinen, P. (1997). The effect of changes in the consumption of macrolide antibiotics on erythromycin resistance in group A streptococci in Finland. Finnish Study Group for Antimicrobial Resistance. New England Journal of Medicine 337, 441-6.

4. Cizman, M., Pokorn, M., Seme, K. Orazem, A. \& Paragi, M. 2001.Correlation between increased consumption of fluoroquinolones in outpatients and resistance of Escherichia coli from urinary tract infections. Journal of Antimicrobial Chemotherapy 47, 495-502.

5. Austin, D. J. \& Anderson, R. M. (1999). Studies of antibiotic resistance within the patient, hospitals and the community using simple mathematical models. Philosophical Transactions of the Royal Society of London Series B Biological Sciences 354, 721-738.

6. Levy, S.B. (2001). Antibiotic resistance: consequences of inaction. Clinical Infectious Diseases 33 , Suppl. 3, 124-9.

7. Goldmann, D. A. (1999). The epidemiology of antimicrobial resistance. Ecosystem Health 5, 158163.

8. Sattar, S.A., Tetro, J. \& Springthorpe, V. S. (1999). Impact of changing societal trends on the spread of infections in American and Canadian homes. American Journal of Infection Control 27, Suppl., 421.

9. Levy, S. B. (1998). The challenge of antibiotic resistance. Scientific American 278, 46-53.

10. Van den Bogaard, A. E., London, N. \& Stobberingh, E. E. (2000). Antimicrobial resistance in pig faecal samples from the Netherlands (five abattoirs) and Sweden. Journal of Antimicrobial Chemotherapy 45, 663-71

11. Levy S. B., Marshall, B., Schluederberg, S., Rowse, D. \& Davis, J. (1988). High frequency of antimicrobial resistance in human fecal flora. Antimicrobial Agents and Chemotherapy 32, 1801-6.

12. Van de Mortel, H. J., Jansen, E. J., Dinant, G. J., London, N., Palacios Pru, E. \& Stobberingh, E. E. (1998). The prevalence of antibiotic-resistant faecal Escherichia coli in healthy volunteers in Venezuela. Infection 26, 292-7.

13. London, N., Nijsten, R., van den Bogaard, A. \& Stobberingh, E. (1993). Antibiotic resistance of faecal Enterobacteriaceae isolated from healthy volunteers, a 15-week follow-up study. Journal of Antimicrobial Chemotherapy 32, 83-91. 
14. Bonten , M., Stobberingh, E., Philips, J., \& Houben, A. (1990). High prevalence of antibiotic resistant Escherichia coli in faecal samples of students in the south-east of The Netherlands. Journal of Antimicrobial Chemotherapy 26, 585-92.

15. Nijsten, R., London, N., van den Bogaard, A. \& Stobberingh, E. (1996). Antibiotic resistance among Escherichia coli isolated from faecal samples of pig farmers and pigs. Journal of Antimicrobial Chemotherapy 37, 1131-40.

16. Van den Bogaard, A. E., Mertens, P., London, N. H. \& Stobberingh, E. E. (1997). High prevalence of colonization with vancomcyin and pristinamycin-resistant enterococci in healthy humans and pigs in The Netherlands. Journal of Antimicrobial Chemotherapy 40, 454-6.

17. Huizingh, H. (1999). SPSS voor Windows, $5^{\text {th }}$ edn. Academic Service Economie en Bedrijfskunde, Schoonhoven, the Netherlands.

18. Stobberingh, E., van den Bogaard, A., London, N., Driessen, C., Top, J. \& Willems, R. (1999). Enterococci with glycopeptide resistance in turkeys, turkey farmers, turkey slaughterers, and (sub)urban residents in the South of The Netherlands: evidence for transmission of vancomycin resistance from animals to humans. Antimicrobial Agents and Chemotherapy 43, 2215-2221.

19. Lester, S.C., del Pilar Pla, M., Wang, F., Perez Schael, I., Jiang, H. \& O'Brien, T. F. (1990). The carriage of Escherichia coli resistant to antimicrobial agents by healthy children in Boston, in Caracas, Venezuela, and in Qin Pu, China. New England Journal of Medicine 323, 285-9. 


\section{CHAPTER 5}

\section{Hospitalisation, a Risk Factor for Antibiotic Resistance}

\section{in the Community?}

N. Bruinsma', P.M.G. Filius ${ }^{2}$, A.E. van den Bogaard', S. Nys ${ }^{1}$, J. Degener ${ }^{3}$, H.Ph.

Endtz $^{2}$, and E.E. Stobberingh ${ }^{1}$

'Department of Medical Microbiology, University Hospital Maastricht, The Netherlands

${ }^{2}$ Department of Medical Microbiology and Infectious Diseases, Erasmus MC, University Medical Center Rotterdam, The Netherlands.

${ }^{3}$ Department of Medical Microbiology, University Hospital Groningen, Groningen, The Netherlands

Submitted to the Journal of Antimicrobial Chemotherapy 


\begin{abstract}
The impact of hospitalisation on the prevalence of resistant Escherichia coli in the intestinal flora of patients admitted to the surgical wards of three Dutch university affiliated-hospitals was prospectively analysed. Faecal samples were obtained on admission to the hospital, at time of discharge, and 1 and 6 months after discharge. All samples were examined for resistance to 9 antibiotic agents.

For the total patient population no significant differences in the prevalence of resistance were observed at the different sampling intervals, except for a significant decrease in cefazolin resistance between the time of discharge and 6 months after discharge $(10 \%$ to $3 \%, \mathrm{p}<0.05)$. This decrease was mainly observed in patients from the university hospital Maastricht (azM), in which a significant decrease from $17 \%$ to $6 \%$ was detected $(\mathrm{p}<0.05)$. Moreover, despite dissimilarities in patient characteristics and the marked variations in antibiotic use, no significant differences in the prevalence of antibiotic resistance were observed between the three hospitals, except for the overall higher prevalence of cefazolin resistant $E$. coli in azM patients $(\mathrm{p}<0.05)$.

In conclusion, in this study, hospitalisation did not seem to have any substantial effect on the prevalence of antibiotic resistant $E$. coli at the different time intervals. However as our study population consisted of patients admitted to the surgical wards, with a relatively moderate antibiotic use, studies performed in other hospital populations may produce other results. Therefore further studies regarding the impact of hospitalisation on the prevalence of antibiotic resistance in the community should be encouraged, as the understanding of the interaction between different resistance reservoirs is important for directing future intervention studies.
\end{abstract}




\section{INTRODUCTION}

Antibiotic resistance is an increasing world wide public health problem. It is generally accepted that selection of resistant bacteria by the use of antibiotics is the most important cause of the increase in antibiotic resistance. The hospital is a perfect environment for the selection and dissemination of antibiotic resistant bacteria. Twenty-five to $40 \%$ of hospitalised patients generally receive antibiotics, either for therapy or as prophylaxis ${ }^{4}$. In addition, the spread of resistant bacteria within the hospital is facilitated by a high population density, an extensive use of vascular devices and frequent contacts between patients and healthcare workers 10, 14, 17. Moreover, underlying illnesses and immunosuppression make hospitalised patients more susceptible to colonisation and infection by resistant bacteria ${ }^{7,17}$.

Many studies have shown that hospitalisation can lead to an increase in antibiotic resistance in pathogenic bacteria ${ }^{4-6}$. The effect of hospitalisation on antibiotic resistance of commensal intestinal bacteria, like Escherichia coli has received less attention so far ${ }^{16,20}$. However, resistant commensal bacteria acquired in the hospital may disseminate in the community through discharged patients, just as community bacteria may represent a reservoir for hospital outbreaks. The extend of transfer of resistant bacteria and resistance genes, between these two compartments is unknown, as to our knowledge studies on this topic are lacking.

In the present study, the impact of hospitalisation on the prevalence of resistance in Escherichia coli of the intestinal flora of patients admitted to the surgical wards of three university affiliated-hospitals in The Netherlands was prospectively analysed. $E$. coli was used as indicator organism, as this species is one of the dominant aerobically growing bacteria of the intestinal flora ${ }^{9}$. The study focused on patients admitted to general wards rather then ICUs, because patients discharged from the ICU only represent a very small part of the total number of patients discharged from a hospital. To assess whether hospital acquired resistance contributes to the dissemination of resistance genes and resistant bacteria in the community, the prevalence of resistance was determined on admission, at time of discharge and 1 and 6 months after discharge. 


\section{MATERIALS AND METHODS}

\section{Patient populations}

From 1999-2001, patients admitted to the participating surgical wards of the university hospitals of Groningen (azG), Maastricht (azM), and Rotterdam (azR), The Netherlands, were asked to participate in the present study. Upon inclusion, patients were requested to collect a faecal sample at the following time intervals; within 24 hours after admission to the hospital, at time of discharge, and 1 and 6 months after discharge. Data on antibiotic use and hospitalisation in the three months prior to hospital admission were recorded. At the time of discharge, the reason for surgical admission, the length of stay and the antibiotics prescribed were registered for each patient. One and 6 months after discharge the patients were reminded by mail to send a faecal sample and were asked to fill in a short questionnaire concerning rehospitalisation and antibiotic use in the period between time of discharge and sample collection. Approval of the Medical Ethical Committees was obtained prior to the start of the study. Only patients that had given their informed consent were included in the study.

TABLE 1. Patient characteristics

\begin{tabular}{|c|c|c|c|}
\hline & azG & azM & azR \\
\hline Total number of patients & 83 & 94 & 91 \\
\hline Age (mean (SD)) & $51( \pm 16)$ & $58( \pm 14)$ & $63( \pm 11)$ \\
\hline Sex $(\%$ male $)$ & $41 \%$ & $48 \%$ & $53 \%$ \\
\hline Antibiotic use in the 3 months prior to admission & $25 \%$ & $30 \%$ & $18 \%$ \\
\hline Hospitalisation in the 3 months prior to admission & $27 \%$ & $26 \%$ & $32 \%$ \\
\hline \multicolumn{4}{|l|}{ Reason for surgical admission: } \\
\hline vascular surgery & $0 \%$ & $14 \%$ & $49 \%$ \\
\hline general surgery & $25 \%$ & $18 \%$ & $3 \%$ \\
\hline oncology & $52 \%$ & $21 \%$ & $20 \%$ \\
\hline gastro-intestinal surgery & $23 \%$ & $47 \%$ & $28 \%$ \\
\hline
\end{tabular}




\section{Exclusion criteria}

Patients were not eligible for the study if they were younger than 18 years; were unable to give informed consent; had not resided in the Netherlands during the 6 months preceding admission; or were referred from a nursing home (long-term care facility) or transferred from another ward (in the same or another hospital). Patients were withdrawn from the analysis; if no faecal samples were obtained on admission, at time of discharge or one month after discharge; they stayed for less than 2 days in the hospital; or if they were referred to an intensive care unit for more than 24 hours after surgery.

\section{Sample processing}

All faecal samples were directly diluted $1: 10$ in $0.9 \%(w / v) ~ N a C l$ supplemented with $20 \%(\mathrm{v} / \mathrm{v})$ glycerol and stored at $-20{ }^{\circ} \mathrm{C}$ at the laboratories of the participating hospitals. Subsequently those of azG and azR were transported on dry ice to the microbiological laboratory of the azM, where the prevalence of antibiotic resistance was determined, as described previously ${ }^{13}$. In short, after thawing, the samples were further diluted $\left(10^{-2}-10^{-4}\right)$ and $0.04 \mathrm{ml}$ of these dilutions were spread over eosinemethylene-blue (EMB) agar plates (Oxoid CM 69, Basingstoke, England) without and with antibiotics, using a spiral plater (Salm and Kipp, Utrecht, The Netherlands). In the present study, the minimum detection level for $E$. coli was $10^{3}$ colonies per gram faeces. The antibiotic concentrations used (Table 4) in the agar plates were based on NCCLS guidelines and modified (where appropriate) to make comparison with previous studies possible ${ }^{1,12,15,18,19}$. After incubation $\left(37^{\circ} \mathrm{C}\right.$ for $\left.18-24 \mathrm{~h}\right)$ the colonies of $E$. coli growing on the respective agar plates were counted.

From each EMB agar plate without antibiotics one colony with the morphology of $E$. coli was randomly picked to test the indole reaction and the production of $\beta$ glucuronidase. If both tests were positive the isolate was considered an $E$. coli and stored at $-70{ }^{\circ} \mathrm{C}$. Identification was confirmed by random selection of $50 \mathrm{E}$. coli isolates causing the API 20E system (Biomerieux, s'Hertogenbosch, the Netherlands). 


\section{Analysis}

The prevalence of antibiotic resistance (\%) was defined as the number of faecal samples with resistant $E$. coli divided by the total number of samples with detectable E. coli and multiplied by 100 . The prevalence of resistance against amoxicillin, cefazolin, ciprofloxacin, co-amoxiclav, gentamicin, nalidixic acid, nitrofurantoin, oxytetracycline, and trimethoprim was determined. The consumption of antibiotics during hospitalisation in the three patient populations was expressed as the number of defined daily dosages (DDD) per 100 bed-days. Statistical comparisons were performed using the chi-square test or Fisher's exact test. A p-value $<0.05$ was considered significant.

\section{RESULTS}

\section{Patient populations}

The overall participation rate of the study was approximately $30 \%$. The most frequently reported reason for not enrolling in the study were being physically unable or having psychological reasons. A total of 400 patients were screened for the exclusion criteria of which 268 were included in the study. From all these 268 patients faecal samples were collected on admission, at time of discharge, and 1 month after discharge (Table 1), and of 221 patients a faecal sample was also collected 6 months after discharge $(\mathrm{azG}=59, \mathrm{azM}=80, \mathrm{azR}=82)$.

There was no marked variation in the use of antibiotics and hospitalisation in the three months prior to admission between the three patient populations (Table 1). Almost half of the azM patients were admitted for gastrointestinal surgery, whereas azR patients were admitted most often for vascular surgery and azG patients for oncology related surgery (Table 1). The majority of patients underwent surgery during hospitalisation ( $a z G=99 \%, a z M=86 \%$, azR $=98 \%$ ). The median length of stay for the populations of azM, azR, azG was 10,8 , and 6 days respectively. 
TABLE 2. Consumption of antibiotics for systemic use during hospitalisation in the three patient populations

\begin{tabular}{|c|c|c|c|c|c|c|}
\hline \multirow[t]{2}{*}{ Antibiotic agent } & \multicolumn{6}{|c|}{$\mathrm{DDD} / 100$ bed-days (number of patients prescribed a specific antib } \\
\hline & $\mathrm{azG}$ & & azM & & $\mathrm{azR}$ & \\
\hline Aminopenicillins & 0.0 & & 1.4 & (2) & 0.1 & (1) \\
\hline Flucloxacillin & 0.0 & & 6.0 & (3) & 0.0 & \\
\hline Co-amoxiclav & 14.8 & (4) & 94 & $(81)$ & 21.3 & (8) \\
\hline Cefazolin & 1.5 & (11) & 0.2 & (1) & 2.0 & (44) \\
\hline Cefuroxime & 0.0 & & 0.0 & & 4.0 & $(8)$ \\
\hline Ceftazidime & 0.0 & & 1.1 & (1) & 0.0 & \\
\hline Trimethoprim & 0.0 & & 0.5 & (1) & 0.0 & \\
\hline Cotrimoxazole & 0.8 & (2) & 0.3 & (1) & 1.6 & (3) \\
\hline Erythromycin & 0.0 & & 0.0 & & 2.2 & (2) \\
\hline Clindamycin & 0.0 & & 2.7 & (3) & 4.4 & (3) \\
\hline Aminoglycosides & 2.1 & (3) & 4.5 & (6) & 0.0 & \\
\hline Ciprofloxacin & 13.7 & (17) & 1.3 & (4) & 5.7 & (2) \\
\hline Metronidazole & 1.1 & (4) & 0.8 & (1) & 3.3 & (15) \\
\hline Nitrofurantoin & 0.0 & & 0.4 & (1) & 0.0 & \\
\hline Total & 34 & & 113 & & 45 & \\
\hline
\end{tabular}

Table 2 presents the consumption of antibiotics for systemic use during hospitalisation in the three patient populations. The use of antibiotics varied substantially among the three patient populations. The percentages of patients receiving antibiotics in the patient populations of azM, azR and azG were $93 \%, 62 \%$, and $34 \%$ respectively, whereas the percentages of patients receiving antimicrobial prophylaxis were $78 \%$, $49 \%$ and $34 \%$ respectively. In the azM population co-amoxiclav was used for antimicrobial prophylaxis, and $41 \%$ of the patient population also received coamoxiclav for therapy. For the azR patients the antibiotics used for therapy were diverse, whereas cefazolin with or without metronidazol was exclusively used for prophylaxis. The azG patients were most often prescribed ciprofloxacin for therapy (18\% of the patients) and cefuroxim with or without metronidazol was used for prophylaxis (Table 2). 
Overall, most faecal samples with detectable $E$. coli were derived from azM patients $(80 \%)$, followed by the patient group admitted to azR (75\%), and were lowest among the azG patients $(67 \%)$. A significant higher number of azG patients, where no $E$. coli could be detected in the faecal samples on admission and discharge, consumed antibiotics prior to admission and during hospitalisation respectively. Six month after discharge a reverse association between the prior use of antibiotics and the detection rate of $E$.coli was observed in the azR patients ( $\mathrm{p}<0.05$, Table 3).

\section{Characteristics of patients with detectable E. coli}

In general, comparable percentages of prior antibiotic use and hospitalisation were found between the three patient populations with detectable E. coli on admission, and 1 and 6 months after discharge (Table 3). Ninety-two percent of the azM patients received antibiotics during hospitalisation, which was $61 \%$ and $15 \%$ for the azR and azG patients respectively $(\mathrm{p}<0.05)$ (Table 3 ). Almost half of the azM patients with detectable E. coli $(47 \%)$ underwent a '(clean-) contaminated' surgical procedure, whereas the majority of patients from azR and azG underwent 'clean' surgery $(75 \%$ and $85 \%$ of the cases respectively). A comparable number of the azM and azR patients were hospitalised for 7 days or more, $53 \%$ and $49 \%$ respectively, whereas only $25 \%$ of the azG patients were admitted for 7 days or more.

\section{Antibiotic resistance}

Table 4 presents the prevalence of antibiotic resistance for the samples with detectable $E$. coli on the different time intervals. No significant differences in the prevalence of resistance were found between admission, time of discharge, and 1 and 6 months after discharge, both for the total population as for the separate hospitals. One exception was the significant decrease in the prevalence of cefazolin resistant $E$. coli isolated from the azM patients between discharge $(17 \%)$ and 6 months thereafter $(6 \%)$. In addition, a similar decrease was found for the total patient population $(\mathrm{p}<0.05)$. The azM patients showed a significant higher prevalence of cefazolin resistance on admission, at time of discharge and 1 month after discharge compared to the azG patients and also at time of discharge for the azR patients ( $\mathrm{p}<0.05)$ (Table 5). 
TABLE 3. Detection rate of faecal $E$. coli and relation with prior antibiotic use and hospitalisation at the different time intervals.

\begin{tabular}{|c|c|c|c|c|c|c|}
\hline & \multicolumn{2}{|l|}{ azG } & \multicolumn{2}{|l|}{$\mathrm{azM}$} & \multicolumn{2}{|l|}{ azR } \\
\hline & detection & no detection & detection & no detection & detection & no detection \\
\hline & of E.coli & of E.coli & of E.coli & of E.coli & of E.coli & of E.coli \\
\hline \multicolumn{7}{|l|}{ Admission } \\
\hline Total number of patients & 50 & 33 & 76 & 18 & 57 & 34 \\
\hline Antibiotic use in the preceding 3 months & $7(14 \%)^{a}$ & $14(42 \%)$ & $21(28 \%)$ & $7(39 \%)$ & $11(19 \%)$ & $5(15 \%)$ \\
\hline Hospitalisation in the preceding 3 months & $12(24 \%)$ & $10(30 \%)$ & $19(25 \%)$ & $5(28 \%)$ & $16(28 \%)$ & $13(38 \%)$ \\
\hline \multicolumn{7}{|l|}{ At time of discharge } \\
\hline Total number of patients & 53 & 30 & 75 & 19 & 71 & 20 \\
\hline Antibiotic use during hospitalisation ${ }^{b}$ & $8(15 \%)^{2}$ & $20(67 \%)$ & $69(92 \%)$ & $18(95 \%)$ & $43(61 \%)$ & $13(65 \%)$ \\
\hline \multicolumn{7}{|l|}{1 month after discharge } \\
\hline Total number of patients & 63 & 20 & 74 & 20 & 70 & 21 \\
\hline Antibiotic use in the preceding month & $8(13 \%)$ & $4(19 \%)$ & $10(14 \%)$ & $3(15 \%)$ & $9(13 \%)$ & $4(19 \%)$ \\
\hline Hospitalisation in the preceding month & $7(11 \%)$ & $2(10 \%)$ & $7(10 \%)$ & $0(0 \%)$ & $3(4 \%)$ & $1(5 \%)$ \\
\hline \multicolumn{7}{|l|}{6 months after discharge } \\
\hline Total number of patients & 40 & 19 & 63 & 17 & 70 & 12 \\
\hline Antibiotic use in the preceding 5 months $^{b}$ & $14(35 \%)$ & $9(47 \%)$ & $7(11 \%)$ & $2(12 \%)$ & $15(21 \%)^{a}$ & $1(8 \%)$ \\
\hline Hospitalisation in the preceding 5 months & $5(13 \%)$ & $2(11 \%)$ & $9(14 \%)$ & $2(12 \%)$ & $16(23 \%)$ & $2(17 \%)$ \\
\hline
\end{tabular}

a) significant difference within a hospital $(p<0.05)$.

b) significant difference for patients with detectable $E$. coli between the hospitals ( $p<0.05$ ). 


\section{Amoxicillin, cefazolin and oxytetracycline resistance in relation to patient characteristics}

Hardly any associations were found between the patient related risk factors (age, sex, antibiotic use, hospitalisation, length of stay, and type of surgery) at the different time intervals and the prevalence of amoxicillin, cefazolin, and oxytetracycline resistant $E$. coli. The only observed association was for antibiotic use during hospitalisation and cefazolin resistance at time of discharge (Table 5).

\section{DISCUSSION}

For the total patient population no significant differences in the prevalence of antibiotic resistance in $E$. coli were observed at the different sampling intervals. Moreover, despite the dissimilarities in patient characteristics and the variations in quantities and types of antibiotics used during hospitalisation, no significant differences in the prevalence of antibiotic resistance were observed between the three hospitals, except for cefazolin resistance. A significant decrease in the prevalence of cefazolin resistance between the faecal samples of azM patients collected at time of discharge $(17 \%)$ and 6 months later $(6 \%)$ was observed. For the total patient population this also resulted in a significant decrease in cefazolin resistance between time of discharge and 6 months later. In general, the observed prevalence of antibiotic resistance in faecal $E$. coli on admission was almost similar to the prevalence of resistance found in faecal $E$. coli of healthy volunteers from Maastricht, Rotterdam, and Groningen in a previous study '

Although the overall prevalence of antibiotic resistance remains stable at the different time intervals, the density of colonisation by resistant bacteria in the commensal flora may increase. This is important, as increasing numbers of resistant bacteria enhances the chance of dissemination into the environment and to other hosts. However, in the present study, no difference in the density of colonisation by resistant bacteria was found at the different time intervals (data not shown). 
TABLE 4. The prevalence (\%) of antibiotic resistance per hospital determined for the samples with detectable $E$. coli".

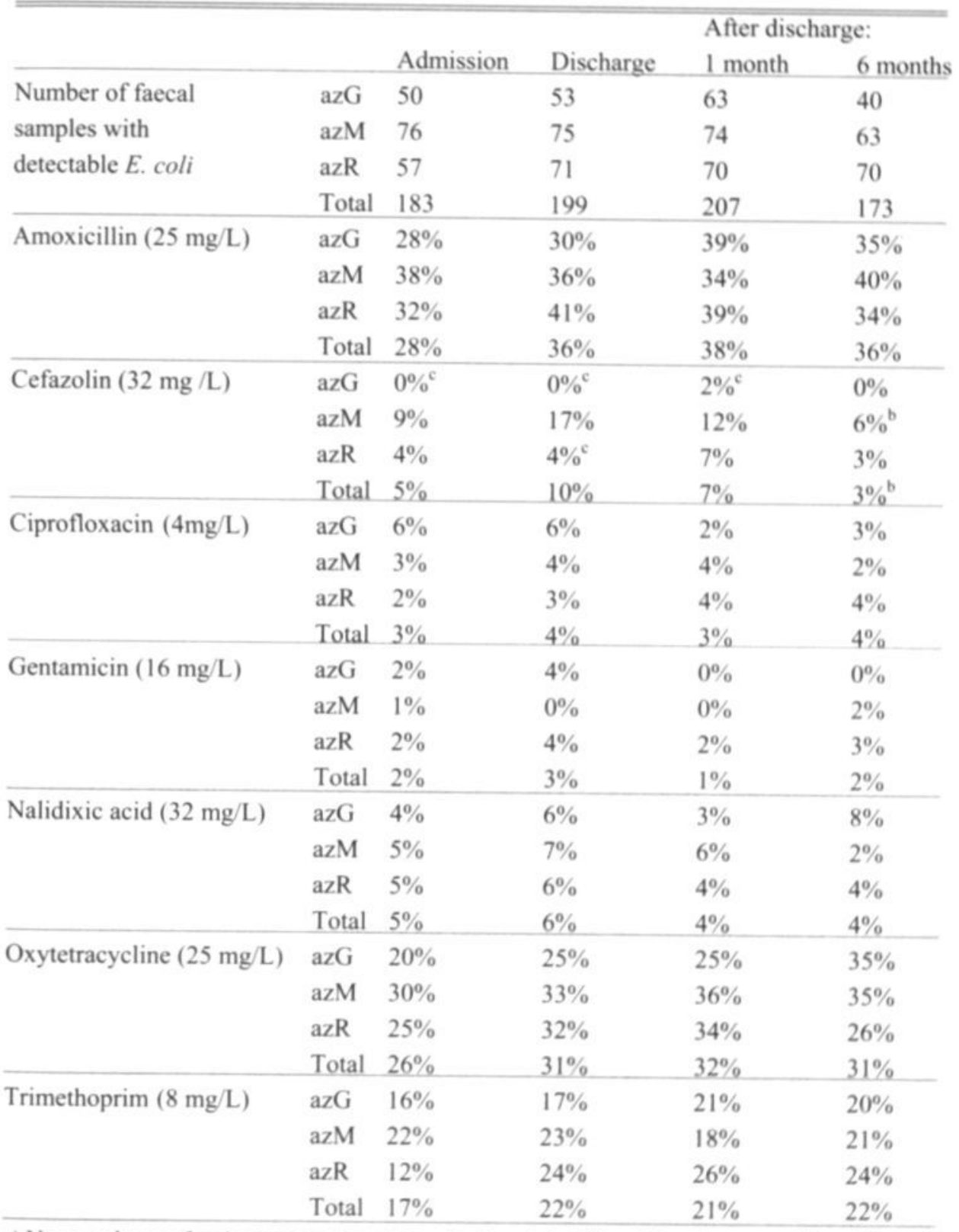

a) No prevalence of resistance was found for nitrofurantoin $(50 \mathrm{mg} / \mathrm{L})$ and co-amoxiclav $(32 \mathrm{mg} / \mathrm{L})$.

b) Significant difference between discharge and 6 months after discharge within a hospital ( $<<0.05)$

c) Significant difference compared to azM within a time interval $(\mathrm{p}<0.05)$. 
TABLE 5. The association between hospital-related risk factors and the prevalence of amoxicillin, cefazolin, and oxytetracycline resistant E. coli at time of discharge.

\begin{tabular}{llllll}
\hline & \multicolumn{2}{l}{ Resistance prevalence } & RR & $95 \%$ CI & P-value \\
\hline Length of stay & $<7$ days $(\mathrm{n}=111)$ & $\geq 7$ days $(\mathrm{n}=88)$ & & \\
\hline Amoxicillin & $36 \%$ & $36 \%$ & 1.01 & $0.78-1.46$ & 0.68 \\
Cefazolin & $5 \%$ & $11 \%$ & 2.10 & $0.86-2.30$ & 0.17 \\
Oxytetracycline & $31 \%$ & $31 \%$ & 1.00 & $0.76-1.5$ & 0.69 \\
Antibiotic use yes & $(\mathrm{n}=120)$ & no $(\mathrm{n}=79)$ & & & \\
\hline Amoxicillin & $39 \%$ & $34 \%$ & 1.24 & $0.88-1.69$ & 0.22 \\
Cefazolin & $13 \%$ & $1 \%$ & 9.87 & $1.03-3.03$ & 0.04 \\
Oxytetracycline & $30 \%$ & $34 \%$ & 0.94 & $0.74-1.46$ & 0.84 \\
\hline Surgery" & clean $(\mathrm{n}=124)$ & $($ clean-) contaminated $(\mathrm{n}=65)$ & \\
\hline Amoxicillin & $37 \%$ & $37 \%$ & 1.02 & $0.78-1.50$ & 0.64 \\
Cefazolin & $5 \%$ & $12 \%$ & 2.78 & $0.91-2.43$ & 0.11 \\
oxytetracycline & $32 \%$ & $28 \%$ & 0.96 & $0.73-1.52$ & 0.78 \\
\hline
\end{tabular}

a)Only the patients $(\mathrm{n}=189)$ that underwent surgery are included.

Selection pressure by antibiotics is considered the most important factor in the emergence of antibiotic resistance. The azM patients were most widely exposed to antibiotics. This high use of antibiotics can be explained by the fact that the majority of azM patients underwent (clean-) contaminated surgery, which because of higher infection risk is an indication for antimicrobial prophylaxis ${ }^{8}$, whereas the majority of azR and azG patients underwent 'clean' surgery ( $75 \%$ and $85 \%$ respectively). However, the higher selection pressure in azM patients due to the use of co-amoxiclav, did not seem to have any effect on the observed prevalence of co-amoxiclav or amoxicillin resistance. The patients that used antibiotics during hospitalisation showed a significant higher of cefazolin resistance at the time discharge. One might speculate that the high use of co-amoxiclav induced the increase in cefazolin resistance observed at time of discharge. The use of cefazolin for prophylaxis in the azR did not seem to effect the prevalence of cefazolin resistance. The other risk factors that could have influenced the prevalence of antibiotic resistance like sex, age, antibiotic use, reason of 
surgery, and re-hospitalisation did not display any significant differences at the different time intervals.

A significant higher number of azG patients that received antibiotics during hospitalisation had no detectable $E$. coli in their faecal samples at time of discharge. In the patient population of the azG ciprofloxacin was frequently used. This drug eliminates or strongly suppresses intestinal Enterobacteriaceae ${ }^{3}$ and is therefore the drug of choice for selective decontamination of the gastrointestinal tract. In combination with the relatively short hospital stay of the azG patients in this study this might explain the relatively high number of samples with no detectable $E$. coli.

More difficult to explain are the relatively large groups of samples with no detectable E. coli on admission for both azG and azR patients. As the human commensal flora generally contains $10^{8}-10^{9}$ E.coli per $\mathrm{ml}$ faeces in $85 \%$ to $90 \%$ of the cases ${ }^{2}$, and the minimum detection level in the present study was approximately $10^{3}$ colonies per gram faeces, the lack of sensitivity of the used methods is not a likely explanation. The observed differences in the level of detectable $E$. coli between the time intervals and the hospitals might have biased the prevalence of antibiotic resistance found.

A reverse relation of antibiotic use and the detect ability of $E$. coli was observed for the azR patients 6 months after discharge, where a significant higher number of detectable E. coli was observed among the azR patients that used antibiotics. Indeed, antibiotic treatment can have opposite effects on the commensal flora and vary substantially between agents. For example, amoxicillin can cause an increase of Enterobacteriae in the commensal flora, whereas fluoroquinolones can eliminate or strongly suppress them ${ }^{3}$.

In conclusion, and with the exception of cefazolin resistance, hospitalisation did not seem to have any substantial effect on the prevalence of antibiotic resistant $E$. coli at the different time intervals, nor did the large dissimilarities of the patient characteristics and the variations in selection pressure of antibiotics between the three hospital populations. However, one can not exclude that resistant bacteria from hospitals disseminate into the environment and to new hosts once the patient leaves the hospital ${ }^{7,11}$. On surgical wards antibiotic use is still relatively low compared to other wards like haematology or ICUs, which results in a higher selection pressure, and 
perhaps would lead to a more pronounced effect on the prevalence of antibiotic resistance. In addition, the average length of stay in these wards is usually longer and patients are often severely immunocompromised, which facilitates dissemination of and colonisation by antibiotic resistant bacteria.

Studies regarding the impact of hospitalisation on the prevalence of antibiotic resistance in the community should be encouraged, as the understanding of the interaction between resistance reservoirs is important for directing future interventions.

\section{ACKNOWLEDGEMENTS}

This investigation was financially supported by the foundation "ZorgOnderzoek Nederland" (grant no.: 97-1-104). We thank the nursing staff of the surgical wards for their assistance in collecting the faecal samples and L. Hoffman, C. Driessen, Dr. N. London, M. Schneiderberg, P.J.E. Roovers, and L. Wildeboer for technical assistance. 


\section{REFERENCES}

1. Bruinsma, N, Filius, PMG, de Smet, PAGM, Degener, J, Endtz, Ph, van den Bogaard AE, Stobberingh, EE. Antibiotic Usage and Resistance in different regions of the Dutch Community. Microb Drug Resist 8; 3 (fall), 2002.

2. Drasar B.S. and P.A. Barrow. Intestinal Microbiology (1985) Van Nostrand Reinhold (UK) C0. Ltd Wokingham, UK

3. Edlund C, Nord CE. Effect on the human normal microflora of oral antibiotics for treatment of urinary tract infections. JAC 46 (Suppl. S1): 41-48, 2000.

4. Gaynes R. The impact of antimicrobial use on the emergence of antimicrobial-resistant bacteria in hospitals. Infect Dis Clin North Am 11 (4): 757-65, 1997.

5. Gaynes R, Monnet D. The contribution of antibiotic use on the frequency of antibiotic resistance in hospitals. Ciba Found Symp 207: 47-56; discussion 56-60, 1997.

6. Giamarellou H, Antoniadou A. The effect of monitoring of antibiotic use on decreasing antibiotic resistance in the hospital. Ciba Found Symp 207: 76-86; discussion 86-92, 1997.

7. Goldmann DA. The epidemiology of antimicrobial resistance. Ecosyst Health 5 (3): 158-163, 1999.

8. Kasteren van, MEE, Gyssens IC, Kullberg, BJ, Bruining HA, Stobberingh EE, Goris RJA. Optimaliseren van het antibioticabeleid in Nederland. V. SWAB-richtlijnen voor perioperatieve antibiotische profylaxe. Ned Tijdschr Geneekd 144:43, 2000.

9. Klare I, Heier H, Claus H, Bohme G, Marin S, Seltmann G, Hakenbeck R, Antanassova V, Witte

W. Enterococcus faecium strains with vanA-mediated high-level glycopeptide resistance isolated from animal foodstuffs and fecal samples of humans in the community. Microb Drug Resist 1 (3): 265-72, 1995 .

10. Levin SA, Andreasen V. Disease transmission dynamics and the evolution of antibiotic resistance in hospitals and communal settings - Commentary. Proc Nat Ac Sc USA 96 (3): 800-801, 1999.

11. Levy SB. The challenge of antibiotic resistance. Sc. American 278 (3): 46-53, 1998.

12. London N, Nijsten R, van der Bogaard A, Stobberingh E. Carriage of antibiotic-resistant Escherichia coli by healthy volunteers during a 15-week period. Infection 22 (3): 187-92, 1994.

13. London N, Nijsten R, vd Bogaard A, Stobberingh E. Antibiotic resistance of faecal Enterobacteriaceae isolated from healthy volunteers, a 15-week follow-up study. J Antimicrob Chemother 32 (1): 83-91, 1993.

14. McGowan JE. Drug resistance and nosocomial infections: epidemiology and prevention strategies. Baill Clin Infect Dis 5 (2): 177-192, 1999.

15. Nijsten R, London N, van den Bogaard A, Stobberingh E. Resistance in faecal Escherichia coli isolated from pigfarmers and abattoir workers. Epidemiol Infect 113 (1): 45-52, 1994.

16. O'Neill PM, Talboys CA, Roberts AP, Azadian BS. The rise and fall of Escherichia coli O15 in a London teaching hospital. J Med Microbiol 33 (1): 23-7., 1990. 
17. Struelens MJ. The epidemiology of antimicrobial resistance in hospital acquired infections: problems and possible solutions. BMJ 317 (7159): 652-654, 1998.

18. van den Bogaard A, London N, Stobberingh EE. Antimicrobial resistance in pig faecal samples from The Netherlands (five abattoirs) and Sweden. J Antimicrob Chemother 45 (5): 663-671, 2000.

19. van den Bogaard AE, London N, Driessen C, Stobberingh EE. Antibiotic resistance of faecal Escherichia coli in poultry, poultry farmers and poultry slaughterers. J Antimicrob Chemother 47 (6): 763-771, 2001.

20. Wagenlehner F, Stower-Hoffmann J, Schneider-Brachert W, Naber KG, Lehn N. Influence of a prophylactic single dose of ciprofloxacin on the level of resistance of Escherichia coli to fluoroquinolones in urology. Int J Antimicrob Agents 15 (3): 207-11., 2000. 


\section{CHAPTER 6}

\section{Difference in genetic homogeneity of vancomycin} resistant and susceptible Enterococcus faecium isolated from different human and animal sources analysed by amplified fragment length polymorphism.

Nienke Bruinsma', Rob J. L. Willems ${ }^{2}$, Anthony E. van den Bogaard', Marga van Santen-Verheuvel ${ }^{2}$, Nancy London', Christel Driessen', and Ellen E. Stobberingh'

${ }^{1)}$ Department of Medical Microbiology, University Hospital Maastricht, The Netherlands,

${ }^{2}$ Research Laboratory for Infectious Diseases, National Institute of Public Health and the Environment (RIVM), Bilthoven, The Netherlands.

Antimicrobial Agents and Chemotherapy 2002; Vol. 46, No. 9, p. 2779-2783 


\section{ABSTRACT}

The genetic relationship of faecal vancomycin-resistant (VREF) and vancomycinsusceptible Enterococcus faecium (VSEF) ( $\mathrm{n}=178$ ) isolated from the same population of pigs, human healthy volunteers, hospitalised patients (from the Netherlands) and chickens (from the Netherlands and Greece) was studied by amplified-fragment length polymorphism (AFLP). The majority of VREF isolated from pigs, healthy volunteers and hospitalised patients grouped together (genetic similarity $\geq 65 \%$ ). In a previous AFLP-study by our group the VREF isolated from hospitalised patients grouped separately, most likely because these were clinical and not faecal isolates as in the present study. Furthermore, VSEF isolated from humans and pigs were found much more genetically diverse than VREF, whereas VREF and VSEF from chicken clustered together in a separate genogroup (genetic similarity $\geq 65 \%$ ), clearly distinct from humans and pigs. The present study suggests that pigs seem a more important source of VREF for humans than chickens, and that human and pig derived VSEF seem much more heterogeneous than VREF. 


\section{INTRODUCTION}

In countries of the European Union (EU) vancomycin resistant enterococci (VRE) are relatively frequently found in healthy humans in the community and in farm animals, and vancomycin resistance is mostly vanA-mediated. This considerable pool of possibly transmissible vanA-mediated glycopeptide resistance in the EU is very likely caused by the use of avoparcin (an analogue of vancomcyin) as a growth promoter in animal husbandry until April $1997^{14,16}$. Occasionally, genetically related VRE isolates have been found in food animals, meat products ${ }^{5}$, outpatients, and hospitalised patients suggesting that transmission between animals and humans can occur and may contribute to colonisation and subsequently infection in humans 9,11,15.

Thus far, molecular comparison by pulsed-field gel electrophoresis (PFGE) 1. 11. 15. 18 , and amplified-fragment length polymorphism (AFLP) analysis (12, 21) of human- and animal-derived enterococci has been done only on VRE strains and revealed the existence of a common human and pig genogroup, while poultry derived VREF clustered in a separate genogroup. However, typing of the Tn $/ 546$ transposon 1, 4, 10, 13, 20, 22 showed that identical Tn 1546 derivatives were found in humans and poultry suggesting horizontal spread of the vanA transposon from poultry to human.

Until now, it is not known whether VREF constitute a separate population within the E. faecium population, and whether host specific AFLP genogroups are also found among VSEF. Previous studies mainly focused on the genetic relation between animals and humans within one country ${ }^{11,18,21}$. In this study, we used AFLP analysis to study the genetic relationship among 178 vancomycin resistant Enterococcus faecium (VREF) and vancomycin sensitive Enterococcus faecium (VSEF) strains isolated from faecal samples of humans and pigs in the Netherlands and chickens in Greece and the Netherlands. AFLP has the ability to establish a genetic relatedness between strains that, by PFGE, would show no similarity at all. PFGE is the reference standard for tracing the transmission of strains in hospital outbreaks, but is too discriminatory to determine genetic relatedness between epidemiological non-related strains $^{21,7}$. 
The AFLP genogroups defined in the present study were compared to our previous results of host specific genogroups, among 255 VREF from 9 different countries isolated from hospitalised patients, nonhospitalised persons and various animal sources (pigs, poultry, calves, dogs, and cats) ${ }^{21}$. Including vancomcyin susceptible enterococci in molecular epidemiological studies might provide a more extensive insight in the composition of the enterococcal intestinal flora in humans and animals and help to further elucidate the transmission routes and persistence of $E$. faecium strains from animals in the human gut ${ }^{21}$.

Part of the study was presented as a poster at the 41 st Interscience Conference on Antimicrobial Agents and Chemotherapy, Chicago, Illinois, December 15-19, 2001 (abstract 1875).

\section{MATERIALS AND METHODS}

\section{Bacterial isolates}

All VREF isolates and a comparable number of VSEF isolates were derived from four different populations of: 1) healthy individuals $(n=537), 2)$ hospitalised patients $(\mathrm{n}=100), 3)$ pigs $(\mathrm{n}=126)$, and 4) poultry $(\mathrm{n}=139)$. The faecal samples of healthy individuals were collected from volunteers living in the north $(n=129)$, south $(n=171)$ and west $(\mathrm{n}=133)$ of The Netherlands and were selected using random addresses from the telephone directory in 1999. From the southern region faecal samples of healthy volunteers were also collected in $1996(n=104)$. The faecal samples of hospitalised patients came from patients admitted to the surgical ward of the University Hospital Maastricht in 1999. The poultry samples came from Greek $(n=50)$ (kindly provided by Prof. K. Sarris, Thessaloniki, Greece) and Dutch slaughterhouses $(n=89)$. The last group of faecal samples were derived from a Dutch pig slaughterhouse. To prevent multiple sampling from both pigs and poultry from the same farm, faeces were collected from every $300^{\text {th }}$ or more pig and by collecting only one chicken sample in the morning and in the afternoon after evisceration at the slaughtering line. 
All faecal samples were diluted 1:10 in $0.9 \%(\mathrm{w} / \mathrm{v}) \mathrm{NaCl}$ supplemented with $20 \%(\mathrm{v} / \mathrm{v})$ glycerol on the day of arrival at the bacteriological laboratory and were stored at $-20^{\circ} \mathrm{C}$ until assayed. After thawing the samples, $40 \mu \mathrm{l}$ of 10-1 and 10 -3 dilutions were inoculated on KF-Streptococcus agarTM plates (Oxoid CM701; Basingstoke, UK), with and without (a.o.) vancomycin (concentration: $10 \mathrm{mg} / \mathrm{l}$ ) using a spiral plater (Salm en Kip BV, Utrecht, the Netherlands) as previously described ${ }^{6,17}$. After $48 \mathrm{~h}$ of incubation at $42^{\circ} \mathrm{C}$, from each sample one typical enterococcal colony was randomly chosen from the plates with and without vancomycin and identified using generally accepted methods ${ }^{2,17}$.

In total 178 faecal E. faecium isolates were included into the study: 93 VREF and 85 VSEF isolates. Sixty-four isolates were selected from healthy volunteers of which 37 were VREF and 27 were VSEF. Seven VREF and 12 VSEF isolates were derived from the hospitalised patients. A total of 35 (VREF $n=16$, VSEF $n=19$ ) and 34 isolates (VREF $n=19$, VSEF $n=15$ ) came from Greek and Dutch poultry farms respectively and 26 isolates were derived from a Dutch pig slaughterhouse (VREF $n=15$, VSEF $n=11$ ). None of the isolates in the present study were included in our previous study ${ }^{21}$.

\section{AFLP analysis}

All 178 isolates were analysed by AFLP. DNA was isolated, as described elsewhere (20), with the addition of a final ethanol precipitation step to further purify the DNA. The AFLP analysis and the degree of genetic similarity of $\geq 65 \%$ for the AFLP patterns to distinguish genogroups was as previously prescribed ${ }^{21}$. This level of $65 \%$ was arbitrarily set and is not an absolute limit, but distinguished four main genogroups and showed a clear association with the source of the strains. In order to form a specific genogroup the minimal number of strains needed to be 5. The distinguished genogroups were compared to the genogroups of our previous study ${ }^{21}$.

Genotypic diversity based on AFLP typing was calculated by the following equation: genotypic diversity $(\mathrm{GD})=[n /(n-1)]\left(1-\sum x_{i}^{2}\right)$, where $x_{i}$ is the frequency of the $i$ th identical AFLP-type and $n$ is the number of strains ${ }^{8,19}$. Two isolates were considered to have an identical AFLP-type when the similarity of banding patterns was $>95 \%$. This cutoff of $95 \%$ was based on the previous finding that the degree of similarity 
between quadruplicates of the same organism was $95 \%-99 \%{ }^{21}$. When isolates are highly diverse, no two isolates have an identical AFLP-type, and the calculated GD is 1. When all isolates are identical the GD is 0 . Thus an increase in GD suggests an increased level of genetic heterogeneity.

\section{Statistical analysis}

The chi-square test $(2$-sided, $p<0.05)$ was used to analyse the differences in the distribution of the different experimental groups among the AFLP genogroups.

\section{RESULTS}

\section{AFLP analysis}

In total 178 strains, $93 \mathrm{VREF}$ and $85 \mathrm{VSEF}$ originated from different animal and human sources; healthy volunteers, hospitalised patients, pig and poultry, were subjected to AFLP typing. Four main groups with strains that shared $\geq 65 \%$ of their restriction fragments were formed as a result of grouping by AFLP. The VREF isolates from healthy volunteers $(35 / 36)$, hospitalised patients (6/7) and all VREF from pigs $(15 / 15)$ clustered in genogroup A (Figure 1, Table 1) and completely clustered in our previously reported genogroup $\mathrm{A}^{21}$.

Compared to the VREF isolates, the VSEF isolates from humans and pigs were genetically more heterogeneous and were dispersed over the entire dendogram (Figure 1). A significant difference in the distribution of genogroups for the VREF and VSEF isolated from human volunteers and pigs were found $(\mathrm{p}<0.05$, Table 1). Two new genogroups $\mathrm{E}$ and $\mathrm{F}$ mainly consisting of VSEF isolates (11/11 and 8/9 respectively)

were identified in addition to the previous published genogroups ${ }^{21}$. The isolates that clustered in genogroup $\mathrm{E}$ were derived from healthy volunteers $(9 / 11)$ and hospitalised patients $(2 / 11)$ and the isolates in genogroup $\mathrm{F}$ were isolated from hospitalised patients $(2 / 9)$, pigs (4/9) and poultry (3/9) (Figure 1, Table 1).

A total of 15 strains were not assigned to any of the genogroups since they did not cluster with $\geq 5$ strains. The majority of these strains were vancomycin sensitive $(12 / 15)$ and were isolated from healthy volunteers $(10 / 12)$ and hospitalised patients 
(2/12) (Figure 1, Table 1). The genetic heterogeneity of VSEF was also confirmed by the higher value of the genotypic diversity of the vancomycin-sensitive enterococci isolated from human volunteers, hospitalised patients and pigs $(1.00,0.97$, and 0.95 respectively) compared to that of the vancomycin-resistant isolates $(0.77,0.87$, and 0.84 respectively) (Table 2 ).

The vast majority of the poultry isolates (65/69) grouped in genogroup B (Figure 1) and also completely clustered within the previously reported genogroup $\mathrm{B}^{21}$. The poultry isolates grouped clearly separately from isolates recovered from humans and pigs, irrespective of whether they were VREF or VSEF, or from Dutch or Greek origin (Figure 1, Table 1). This clustering of poultry related VREF and VSEF also means that the difference in genotypic diversity was smaller between VSEF and VREF from poultry ( 0.93 and 0.88 , respectively) than VSEF and VREF from humans and pigs (Table 2).

TABLE 1. Distribution of isolates of the different experimental groups among the AFLP genogroups

\begin{tabular}{|c|c|c|c|c|c|c|c|c|}
\hline \multirow{3}{*}{$\begin{array}{l}\text { AFLP } \\
\text { genogroups }\end{array}$} & \multicolumn{8}{|c|}{ No. $(\%)$ of isolates of indicated type in: } \\
\hline & \multicolumn{2}{|c|}{ healthy volunteers } & \multicolumn{2}{|c|}{ hospital patients } & \multicolumn{2}{|l|}{ poultry } & \multicolumn{2}{|l|}{ pigs } \\
\hline & VREF $^{a}$ & VSEF $^{a}$ & VREF & VSEF & VREF & VSEF & VREF $^{a}$ & VSEF $^{a}$ \\
\hline A & $35(97 \%)$ & $6(22 \%)$ & $6(86 \%)$ & $5(38 \%)$ & & & $15\left(100^{\circ}\right.$ & $5(46 \%)$ \\
\hline B & & $2(7 \%)$ & & $2(15 \%)$ & $33(94 \%$ & o) $32(94$ & $\%)$ & \\
\hline $\mathrm{E}$ & & $9(33 \%)$ & & $2(15 \%)$ & & & & \\
\hline $\mathrm{F}$ & & & & $2(15 \%)$ & $1(3 \%)$ & $2(6 \%)$ & & $4(36 \%)$ \\
\hline Unrelated & $1(3 \%)$ & $10(37 \%)$ & $1(8 \%)$ & $2(15 \%)$ & $1(3 \%)$ & & & $2(18 \%)$ \\
\hline Total & 36 & 27 & 7 & 13 & 35 & 34 & 15 & 11 \\
\hline
\end{tabular}

${ }^{a} \mathrm{p}<0.05$, a significant difference in the distribution of the genogroups for the VREF and VSEF isolated from human volunteers and pigs were found.

\section{DISCUSSION}

In our previous study, 255 VREF strains from different human and animal sources were subjected to AFLP typing. Four genogroups (A-D), with clustering of isolates from nonhospitalised volunteers and pigs in genogroup A, chickens in genogroup B, 
hospitalised patients in genogroup $\mathrm{C}$, and veal calves in genogroup $\mathrm{D}$ were discriminated ${ }^{21}$. In the present study, the VREF strains from (nonhospitalised) healthy volunteers and pigs also clustered in the same genogroup A. However, the strains from hospitalised patients also clustered in genogroup A, whereas in the previous study they formed a genetically distinct genogroup C. This observed difference between the two studies may be explained by the fact that in this study the VREF derived from hospitalised patients were not clinical isolates from infections or associated with hospital outbreaks, but were isolates from the faecal flora. Therefore, it is very likely that the VREF isolates derived from hospitalised patients were already acquired in the community, as also found by Endtz et al. (1997) ${ }^{3}$.

TABLE 2. Genotypic diversity found in the different experimental groups.

\begin{tabular}{|c|c|c|c|}
\hline \multirow[t]{2}{*}{ Source } & \multirow[t]{2}{*}{ Country" } & \multicolumn{2}{|c|}{ Genetic Diversity $^{\mathrm{b}}$} \\
\hline & & VREF & VSEF \\
\hline Healthy volunteers & NL & 0.77 & 1.00 \\
\hline Hospitalised patients & $\mathrm{NL}$ & 0.87 & 0.97 \\
\hline Pigs & NL & 0.84 & 0.95 \\
\hline Poultry & NL, GR & 0.88 & 0.93 \\
\hline
\end{tabular}

The VREF strains derived from healthy volunteers in 1996 and 1999 and from different regions in the Netherlands showed no specific clustering of AFLP patterns by year or place, and mainly clustered in genogroup A (specific data not shown).

The genetic similarity found for VREF between human and pig isolates was not present among the VSEF isolates. Especially, the VSEF derived from healthy volunteers were genetically more diverse then their resistant counterparts and were spread among genogroup A, B, and E. In addition, $38 \%$ did not cluster in one of the four main genogroups at all. Even though the number of VSEF derived from hospitalised patients $(n=12)$ and pigs $(n=11)$ was smaller, they also showed more genetic diversity than the resistant strains. 


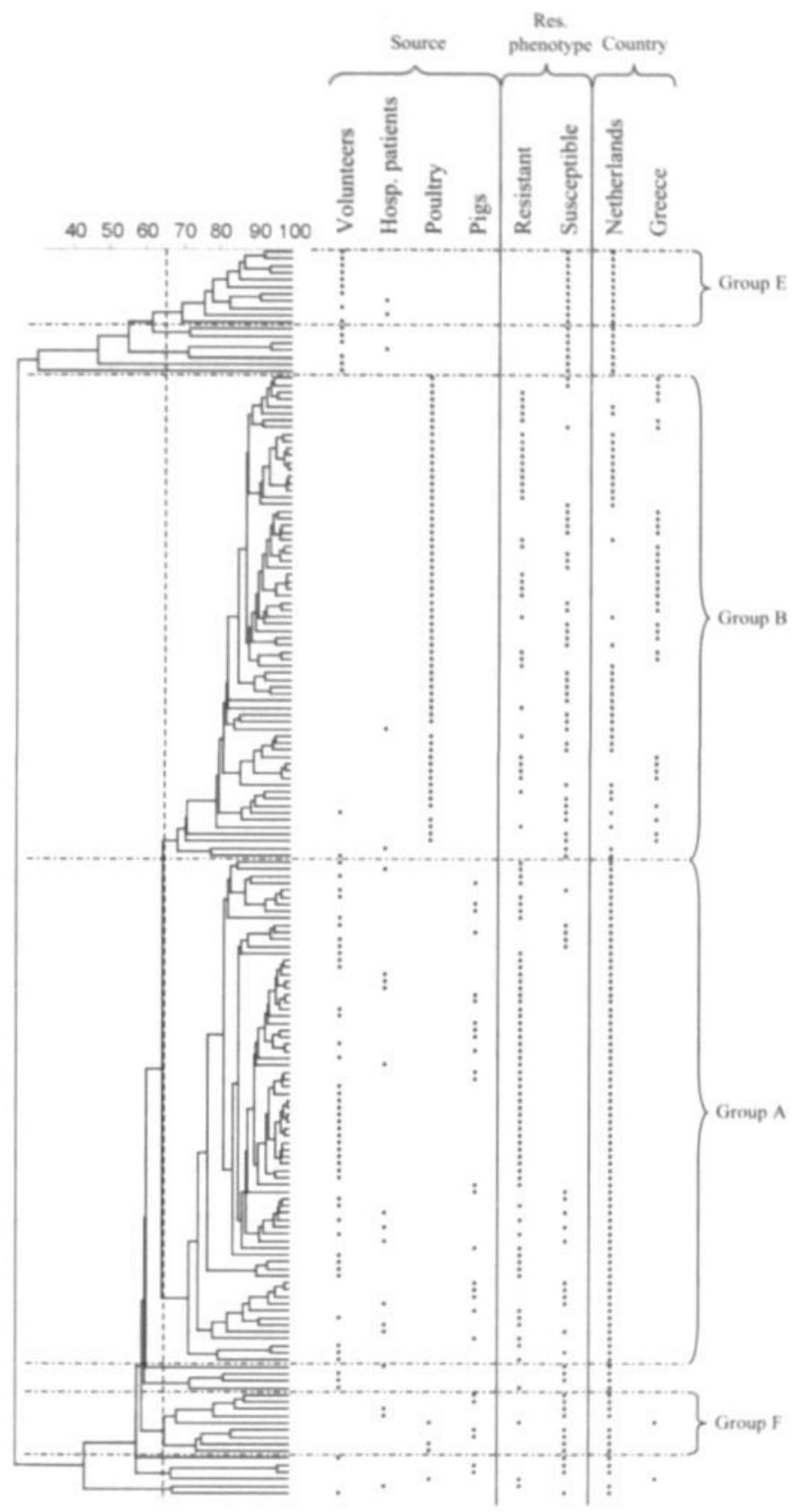

FIGURE 1. Dendogram of the genetic similarity of all isolates by AFLP-analysis. Group A, $\mathrm{B}, \mathrm{E}$ and $\mathrm{F}$ are based on $\mathrm{a} \geq 65 \%$ genetic similarity. The dots restore the source, the vancomycin resistance phenotype and the country origin of the isolates. 
In contrast to the clear distinction between the more homogeneous VREF and more heterogeneous VSEF strains derived from both humans and pigs, the vast majority of VREF and VSEF derived from chickens clustered in genogroup B, and displayed a more or less identical genotypic diversity. Perhaps the antibiotics especially used in poultry farming have already selected for a specific genetic poultry E. faecium population.

The strains isolated from Dutch and Greek chicken present in genogroup B, suggests that the clustering of strains may be more related to the type of animal they were isolated from than their geographic origin. However most broilers in the world are not only genetically related, but also descend from only a few breeding centres. Hence a common source of contamination cannot be excluded.

The finding of a separate (VREF) poultry group (by AFLP analysis) distinct from human isolates was also reported in our previous study ${ }^{21}$. Also, van den Braak et al. (1998) found two major PFGE types of VRE among poultry derived strains that were not found in the faecal flora of patients ${ }^{18}$.

These results suggest that clonal transmission of VREF via the food chain from chicken to humans is less important than from pigs to humans. This might be due to the fact that chicken specific VREF strains may have difficulty in persisting in the human intestinal tract. Nevertheless, similar PFGE and AFLP types between turkey and turkey farmers ${ }^{11,21}$, poultry and poultry farmers ${ }^{21}$ have been found indicating that clonal dissemination of poultry strains to corresponding farmers does occur. For comparison between different typing methods a subset of strain from this study is subjected to a multilocus sequence typing (MLST) scheme developed by our group, and a manuscript describing this MLST scheme for E. faecium has been published ${ }^{3 a}$. In conclusion, human and pig derived VSEF strains are much more heterogeneous than their resistant counterparts and do not form a single genogroup. The VREF strains derived from humans and pigs are genetically different from the majority of the VSEF from pigs and humans and VREF and VSEF from poultry. These results suggest that pigs are a more important VREF source for humans than chickens by way of clonal dissemination. Why strains derived from chicken do not seem to persist or survive as well as pig strains in the human gut remains to be elucidated. More research on strain 
specific traits derived from different human and animal sources -like (virulence factors), colonisation and persistence abilities- is warranted, as they may play a crucial role in the transmission and survival of resistant bacteria in the human gut.

\section{ACKNOWLEDGEMENTS}

This work was financially supported by ZorgOnderzoek Nederland (ZON), The Netherlands [97-1-104]. 


\section{REFERENCES}

1. Descheemaeker, P. R. M., S. Chapelle, L. A. Devriese, P. Butaye, P. Vandamme, and H. Goossens. 1999. Comparison of glycopeptide-resistnat Enterococcus faecium isolates and glycopeptide resistance genes of human and animal origins. Antimicrob. Agents Chemother. 43:2032-2037.

2. Devriese, L. A., A. V. D. Kerckhove, R. Klipper-Balz, and K. H. Schleifer. 1987. Characterization and identification of Enterococcus species isolated from the intestines of animals. Int. J. Syst. Bacteriol. $37: 257-259$.

3. Endtz, H. P., N. van den Braak, A. van Belkum, J. A. J. W. Kluytmans, J. G. M. Koeleman, L. Spanjaard, A. Voss, A. J. L. Weersink, C. M. J. E. Vandenbroucke-Grauls, A. G. M. Buiting, A. van Duin, and H. A. Verbrugh. 1997. Faecal carriage of vancomycin-resistant enterococci in hospitalized patients and those living in the community in The Netherlands. J. Clin. Microb. 35:3026-3031.

3a. Homan, W. L., D. Tribe, S. Poznanski, M. Li. G. Hogg, E. Spalburg, J. D. A. van Embden, and R. J. L. Willems. 2002. Multilocus sequence typing scheme for Enterococcus faecium. J. Clin. Microbiol. 35:3026-3031.

4. Jensen, L. B. 1998. Differences in the occurrence of two base pair variants of $\mathrm{Tn} / 546$ from vancomycin-resistant enterococci from humans, pigs, and poultry. Antimicrob. Agents Chemother. 42:2463-2464.

5. Klare, I., H. Heier, H. Claus, G. Bőhme, S. Marin, G. Seltmann, R. Hakenbeck, V. Antanassova, and W. Witte. 1995. Enterococcus faecium strains with vanA-mediated high-level glycopeptide resistance isolated from animal foodstuffs and fecal samples of humans in the community. Microb. Drug Resist. 1:265-272.

6. London, N., R. Nijsten, A. van den Bogaard, and E. Stobberingh. 1993. Antibiotic resistance of fecal enterobacteriaceae isolated from healthy volunteers, a 15-week follow-up study. J. Antimicrob. Chemother. 32:83-91.

7. Maiden, M. C. J., J. A. Bygraves, E. Feil, G. Morelli, J. E. Russell, R. Urwin, Q. Zhang, J. Zhou, K. Zurth, D. A. Caugant, L. M. Feavers, M. Achtman, and B. G. Spratt. 1998. Multilocus sequence tping: A portable approach to the identification of clones within populations of pathogenic microorganisms. Proc. Natl. Acad. Sci. USA 95: 3140-3145,

8. Nei, M., and F. Tajima. 1981. DNA polymorphism detectable by restriction endonucleases. Genetics 97:145-163.

9. Robredo, B., K. V. Singh, F. Baquero, B. E. Murray, and C. Torres. 2000. Vancomycin-resistant enterococci isolated from animals and food. Intern. J. Food. Microbiol. 54: 197-204.

10. Schouten, M. A., R. J. L. Willems, W. A. G. Kraak, J. Top, J. A. A. Hoogkamp-Korstanje, and A. Voss. 2001. Molecular analysis of Tn1546-like elements in vancomycin-resistant enterococci isolated from patients in Europe shows geographic transposon type clustering. Antimicrob. Agents Chemother. 45:986-989.

11. Stobberingh, E., A. van den Bogaard, N. London, C. Driessen, J. Top, and R. Willems. 1999. 
Enterococci with glycopeptide resistance in turkeys, turkey farmers, turkey slaughterers, and (sub)urban residents in the South of The Netherlands: evidence for transmission of vancomycin resistance from animals to humans. Antimicrob. Agents Chemother. 43:2215-2221.

12. Vancanneyt, M., A. Lombardi, C. Andrighetto, E. Knijff, S. Torriani, K. J. Blorkroth, C. M. A. P. Franz, M. R. Foulquié Moreno, H. Revets, L. De Vuyst, J. Swings, K. Kersters, F. Dellaglio, and W. H. Holzapfel. 2002. Intraspecies genomic groups in Enterococcus faecium and their correlation with origin and pathogenicity. Appl. Environ. Microbiol. 68: 1381-1391.

13. Van den Bogaard, A. E., L. B. Jensen, and E. E. Stobberingh. 1997. Vancomycin-resistant enterococci in turkeys and farmers. New Eng. J. Med. 337:1558-1559.

14. Van den Bogaard, A. E., and E. E. Stobberingh. 1999. Antibiotic use in animals: impact on bacterial resistance and public health. Drugs 58:589-607.

15. Van den Bogaard, A. E., N. London, and E. E. Stobberingh. 2000. Antimicrobial resistance in pig fecal samples from The Netherlands (five abattoirs) and Sweden. J. Antimicrob. Chemother. 45:663671.

16. Van den Bogaard, A. E., N. Bruinsma, , and E. E. Stobberingh. 2000. The effect of banning avoparcin on VRE carriage in The Netherlands. J. Antimicrob. Chemother. 46:145-153.

17. Van den Bogaard, A. E., M. Hazen, M. Hoyer, P. Oostenbach, and E. E. Stobberingh. 2002. Effects of flavophospholipol on resistance in fecal Escherichiae coli and enterococci of fattening pigs. Antimicrob. Agents and Chemother. 46:110-118.

18. Van den Braak, N., A. van Belkum, M. van Keulen, J. Vliegenhart, H. A. Verbrugh, and H. P. Endtz. 1998. Molecular characterization of vancomycin-resistant enterococci from hospitalized patients and poultry products in The Netherlands. J. Clin. Microbiol. 36:1927-1932.

19. Van Loo, I. H. M., H. G. J. van der Heide, N. J. D. Nagelkerke, J. Verhoef, and F. R. Mooi. 1999. Temporal trends in the population structure of Bordatella pertussis during 1949-1996 in a highly vaccinated population. J. Infect. Dis. 179: 915-923.

20. Willems, R. J. L., J. Top, N. van den Braak, A. van Belkum, D. J. Mevius, G. Hendriks, M. van Santen-Verheuvel, and J. D. A. van Embden. 1999. Molecular diversity and evolutionary relationships of Tn1546-like elements in enterococci from humans and animals. Antimicrob. Agents Chemother. 43:483-491.

21. Willems, R. J. L., J. Top, N. van den Braak, A. van Belkum, H. Endtz, D. Mevius, E. Stobberingh, A. van den Bogaard, and J. D. A. van Embden. 2000. Host specifity of vancomcyin-resistant Enterococcus faecium. J. Infect. Dis. 182:816-823.

22. Woodford, N., A-M. A. Adebiyl, M-F. I. Palepou, and B. D. Cookson. 1998. Diversity of vanA glycopeptide resistance elements in enterococci from humans and nonhuman sources. Antimicrob. Agents Chemother. 42:502-508. 


\section{CHAPTER 7}

Summary and General Discussion 


\section{SUMMARY}

Antibiotic resistance poses a serious public health threat. Infections caused by resistant bacteria are often resistant to more than one antibiotic, and are therefore difficult to treat and to control. In 1992, the CDC estimated that more than 13000 hospital patients in the USA died of antibiotic resistant infections. Since then, the number of antibiotic resistant infections and associated deaths has risen every year. Until a few years ago, new antibiotics have always appeared just in the nick of time, before resistance problems got out of hand. However, now the increasingly rapid pace at which bacteria develop and acquire new drug resistance profiles, seem to outpace the rate at which the pharmaceutical industry is able to develop and market new antibiotics.

In the emergence of antibiotic resistance three stages can be differentiated. First susceptible bacteria need to acquire resistance either by mutation or by gaining possessian of new sxggenaus , resistance genes. Whether these resistant strains will survive and replicate depends in large degree on the selection pressure. If due to the increasing use of antibiotics susceptible bacteria present are eliminated, their resistant kin will replace them and the majority of the population will become resistant. The major selection factor is therefore the volume of antibiotic use. The more antibiotics are used, the more they select for resistance. Next to selection pressure of antibiotic use, the dissemination of resistant bacteria and resistance genes is a very important factor for antibiotic resistance to spread. Dissemination of resistant bacteria through direct or indirect contact may cause colonisation by drug-resistant bacteria or transfer of resistance genes to the endogenous flora from one individual to another. The excessive use of antibiotics by mankind has led to the accumulation of large numbers of antibiotic resistant bacteria in the environment and the endogenous flora of man and other animals, that forms an enormous and often underestimated reservoir of resistance genes for pathogenic bacteria. In fact resistance in pathogenic bacteria should be considered as only the top of the resistance iceberg. 
Although most antibiotics are consumed in the community $(80 \%)$, the relation of antibiotic consumption and resistance in the community has been less thoroughly studied. In CHAPTER 2, antibiotic use was related to the prevalence of antibiotic resistant Escherichia coli and enterococci isolated from healthy volunteers living in the south of the Netherlands in 1996 and 1999. In this thesis E. coli and enterococci were used as faecal indicator bacteria belonging to the endogenous flora of humans and animals. No change in the total use of antibiotics the Dutch community was observed between 1996 and 1999 (3,542 and 3,598 DDD/1000 inhabitants/year). However, the increased fluoroquinolone use $(+18 \%)$ and the increased prevalence of ciprofloxacin resistance from zero to $2 \%$ is a point of concern, especially since this was accompanied by a significant shift towards higher MIC values $(p<0.05)$. Furthermore, a significant decrease in the prevalence of vancomycin resistant enterococci $(p<0.05)$ and a significant shift towards lower MIC values for avoparcin, a glycopeptide previously used as growth promoter in animal husbandry, was found $(p<0.05)$. This was most likely the result of the registration suspension of avoparcin use in animals in April 1997 in the EU.

In CHAPTER 3, regional differences of antibiotic use and the prevalence of antibiotic resistant faecal $E$. coli and enterococci, were determined in 3 cities, one in the south (Maastricht), one in the west (Rotterdam) and the other in the north of the Netherlands (Groningen). Differences in antibiotic consumption were observed between the regions of $11.19,10.84$ and 7.16 DDD (defined daily dosage) per 1000 inhabitants per day, for Maastricht, Rotterdam, and Groningen respectively. No significant regional differences were found for the prevalence of antibiotic resistance for both $E$. coli and enterococci. However, the observed differences in antibiotic consumption were mainly for very recently introduced new antibiotics, therefore this might still cause changes in antibiotic resistance in the near future.

Besides selection pressure (antibiotic use), dissemination of resistant bacteria and resistance genes among individuals further extend the prevalence of antibiotic resistance in a population. It is well recognised that dissemination of antibiotic resistant micro-organisms from patient to patient directly, via utensils or health care workers is an important cause of hospital acquired infections and also facilitates the 
transmission of resistant bacteria. Analogous to the hospital situation where patients live closely together in a relatively small area, population density may be considered a crowding factor outside the hospital. In CHAPTER 4 antibiotic consumption and population density were related to the prevalence of antibiotic resistant faecal $E$. coli and enterococci of healthy volunteers living in three cities from three different countries i.e. Canada, Greece, and the Netherlands. In both Newfoundland (Canada) and Greece (Athens) the overall consumption of antibiotics (28 DDD/1000 inhabitants/day (DID)) was more than three times higher compared to that of the Netherlands (9 DID). The lowest prevalence of resistant $E$. coli to the majority of antibiotics tested was found for the samples from Newfoundland and was significant $(p<0.05)$ for cefazolin, oxytetracycline, and trimethoprim. A poor correlation between the number of DID and the prevalence of resistance was observed (the Pearson correlation coefficient (Pcc) ranged between -0.93 and 0.87 ). However, when population density was taken into consideration and antibiotic consumption was expressed in DSD (DDD/square kilometre/day), a strong correlation was found (and Pcc ranged between 0.86 and 1.00). This study suggests that population density is an important factor in the development of antibiotic resistance, and warrants special attention as a factor in resistance epidemiology.

Many studies have shown that hospitalisation can lead to an increase in antibiotic resistance in pathogenic bacteria. However the effect of hospitalisation on the prevalence of antibiotic resistance of commensal intestinal bacteria, like Escherichia coli has been less extensively studied. This was the subject of the study described in CHAPTER 5. The prevalence of antibiotic resistant faecal E. coli of patients admitted to the surgical wards of three Dutch university affiliated-hospitals was prospectively analysed on admission, discharge, 1 and 6 months after discharge. In the study performed, hospitalisation on a population level did not seem to have a substantial effect on the prevalence of antibiotic resistant $E$. coli at the different time intervals. Nor did the dissimilarities of the patient characteristics and the variations in selection pressure of antibiotics between the three patient populations seem to influence the prevalence of antibiotic resistance. On surgical wards antibiotic use is still relatively low compared to other wards like haematology or ICUs, which results in a higher 
selection pressure, and perhaps would lead to a more pronounced effect on the prevalence of antibiotic resistance. In addition, the average length of stay in these wards is usually longer and patients are often severely immunocompromised, which facilitates dissemination of and colonisation by antibiotic resistant bacteria. Studies about the effect of hospitalisation on the prevalence of antibiotic resistance in the commensal flora during and after hospitalisation should be encouraged, as the understanding of interaction between reservoirs is very important in revealing the complexity of antibiotic resistance.

Another very important reservoir of antibiotic resistance interacting with healthy humans in the community, is animal husbandry. In countries of the EU vancomycin resistant enterococci (VRE) are relatively frequently found in faecal samples of healthy humans in the community and in farm animals, which very likely caused by the use of avoparcin (a glycopeptide antibiotic like vancomycin) as a growth promoter in animal husbandry until April 1997. Occasionally, genetically related VRE isolates have been found in food animals, meat products, outpatients, and hospitalised patients suggesting that transmission between animals and humans can occur and may contribute to colonisation and subsequently infection in humans. In CHAPTER 6, the genetic relationship of faecal vancomycin-resistant (VREF) and vancomycinsusceptible Enterococcus faecium (VSEF) $(\mathrm{n}=178)$ isolated from the same population of pigs, human healthy volunteers, hospitalised patients (from the Netherlands) and chickens (from the Netherlands and Greece) was studied by amplified-fragment length polymorphism (AFLP). The majority of VREF isolated from pigs, healthy volunteers and hospitalised patients grouped together (genetic similarity $\geq 65 \%$ ). Furthermore, VSEF isolated from humans and pigs were found much more genetically diverse than VREF, whereas VREF and VSEF from chickens clustered together in a separate genogroup (genetic similarity $\geq 65 \%$ ), clearly distinct from humans and pigs. This suggests that pigs seem a more important source of VREF for humans than chickens, and that human and pig derived VSEF seem much more heterogeneous than VREF. Why strains derived from chicken do not seem to persist or survive as well as pig strains in the human gut remains to be elucidated. More research on strain specific traits derived from different human and animal sources -like (virulence factors), 
colonisation and persistence abilities- is warranted, as they may play a crucial role in the transmission and survival of resistant bacteria in the human gut.

The complexity of the various factors involved in the development and spread of antibiotic resistance can be summarised to 4 stakeholders: the bacteria, the host, antibiotic use and the environment. The correlation between antibiotic use and antibiotic resistance has been generally accepted. However, the fact that no clear direct quantitative correlation between the amounts of antibiotics used and the prevalence of resistance has been found, underlines the complexity of this observed correlation and emphasises the importance to study other factors involved. For example, in Chapter 3 the regional differences in antibiotic consumption did not result into marked differences in the prevalence of antibiotic resistance in these regions, whereas in Chapter 4 population density as a measure of crowding seemed to have a substantial effect on the prevalence of resistance found.

In order to maintain the low level of antibiotic resistance and use in the Netherlands, surveillance of antibiotic resistance on a regional and timely basis in non-clinical isolates in relation to antibiotic use is important. It provides epidemiological data to set up and control antibiotic guidelines and serves as an early warning for resistance to be expected in pathogenic bacteria. Besides the fact that most human antibiotic consumption takes place in the community, other reservoirs of resistance with a high use of antibiotics, like the hospital, animal husbandry, day care centres and nursing homes all interact in the community. Therefore the prevalence and degree of antibiotic resistance in the commensal flora of healthy volunteers in the community occupies a key position in resistance epidemiology and should be considered as a very important source to monitor. 


\section{GENERAL DISCUSSION}

All national, European and international bodies, that have made reports or policy statements on the subject of antibiotic resistance, agree that it is necessary and of utmost importance to improve surveillance of antibiotic resistance and antibiotic usage. Global surveillance is necessary, since resistance genes show no respect for neither geographical nor international borders '. Moreover, global surveillance is the key to understand the magnitude and trends of resistance and to evaluate the impact of interventions ${ }^{7}$. Local surveillance data are, however, important for clinicians needing guidance for therapy and for the management of local resistance problems ${ }^{3}$. An individual hospital may have a different problem from a hospital only a few miles away.

Local and regional data can provide the basis for national and international surveillance data ${ }^{2,5}$. Of course there are quite some obstacles in pooling information obtained locally or regionally to produce overall national data or to compare data internationally. Problems are bound to be encountered with the 1) study design, 2) selection of populations and bacterial species to be studied, 3) sampling methods, 4) susceptibility testing methodology, 5) handling and reporting of results, and, last but not least, 5) funding. This emphasises the importance of collaboration on both national and international levels, standardisation of methodologies, and of data interpretation and analysis. Never is the concept of 'think globally and act locally' more appropriate than in this context ${ }^{4}$.

One of the objectives of surveillance is to guide therapy, but the primary objectives of bacterial resistance surveillance programmes are to provide data describing the prevalence and incidence of resistance within populations over time. In addition, the interaction with other populations as a result of exchange of resistant bacteria or resistance genes between populations can be assessed. Also the effect of changes in selection pressure (=antibiotic use) on the prevalence of antibiotic resistance is an important objective of resistance surveillance. This thesis shows that the prevalence and degree of antibiotic resistance in the commensal flora of healthy volunteers is 
considered an important, so far mainly neglected, source to monitor. The commensal flora of healthy volunteers not only gives data on the prevalence of antibiotic resistance in general, but also provides information on problems that are going to arise in pathogenic bacteria. Therefore, it not only provides a basis for antibiotic prescribing and infection control policies, but also for resistance problems that might be encountered in the community and hospitals. Inevitably, healthy individuals living in the community will at some point have to attend a general practitioner or will be admitted to a hospital.

E. coli and enterococci used as faecal indicator bacteria in this thesis belong to the endogenous flora of humans and animals. They offer several advantages for population-based surveillance over clinical samples (biased) or zoonotic organisms (less commonly isolated and therefore less sensitive) due to the relative ease of sample collection, reproducibility, and the possibility to link prevalence and degree of resistance to antibiotic use in a population. In addition, the ability to compare populations makes it easy to study the transfer of resistance between populations and to target specific populations as reservoirs of resistance. This kind of approach offers a cost-effective method of surveillance, is easy to standardise and can be used all over the world.

Even when resistance surveillance data are of good quality, they are frequently not translated into information for public health action. For too long, the surveillance of antibiotic resistance has been the territory of a selected and relatively 'closed' circle of hospital microbiologists, clinicians, and infection control staff and was only aimed at providing information for therapy and local action and sometimes a scientific publication. However it provided relatively little to the understanding of the impact of resistance in terms of rates of morbidity and mortality, and costs. Even though we can clearly say resistance is costly, there are only a few reports on this subject ${ }^{6}$. In order to convince government authorities to put more funds into confronting this problem, data on increased morbidity, mortality and costs are essential. There is a need for greater epidemiological rigor in resistance surveillance systems so that results can be linked to the incidence, prevalence and outcome of infection. Resistance data need to be 
transformed into a constant flow of information that can be interpreted by public health policymakers ${ }^{7}$.

\section{REFERENCES}

1. Bax R, Bywater R, Cormaglia G, Goossens H, Hunter P, Isham V, et al. Surveillance of antimicrobial resistance - what, how and whither? Clin Microbiol Infect 2001;7:316-25.

2. Huovinen P, Cars O. Control of antimicrobial resistance: time for action. British medical journal $1998 ; 317: 613-4$.

3. Livermore DM, MacGowan AP, Wale MCJ. Surveillance of antimicrobial resistance. British medical journal 1998;317:614-5.

4. Masterton RG. Surveillance studies: how can they help the management of infection? J Anitmicrob Chemother 2000;46 Suppl. T2:53-8.

5. O'Brien TF. The global epidemic nature of antimicrobial resistance and the need to monitor and manage it locally. Clin Infect Dis 1997;24 Suppl 1:S2-8.

6. Rubin RJ, Harrington CA, Poon A, Dietrich K, Greene JA, Moiduddin A. The economic impact of Staphylococcus aureus infection in New York City hospitals. Emerg Infect Dis 1999;5:9-17

7. Williams RJ. Globalization of antimicrobial resistance: epidemiological challenges. Clin Infect Dis 2001;33 Suppl 3:S116-7. 


\section{Nederlandse Samenvatting}


Infecties veroorzaakt door antibiotica resistente bacteriën vormen een toenemend probleem in de volksgezondheid. Wanneer een infectie veroorzaakt wordt door een resistente bacterie, kan dit leiden tot falen van een ingestelde antibiotica therapie met als gevolg ernstigere ziektesymptomen, een verlenging van de ziekteduur en zelfs een verhoogde sterftekans. Bovendien is kostbaar laboratorium onderzoek noodzakelijk om na te gaan voor welk antibioticum de bacterie nog wel gevoelig is. Vaak zal er één van de nieuwere antibiotica gebruikt moeten worden, die een grotere kans op ongewenste bijwerkingen hebben en altijd duurder zijn. Tot voor kort werd dit niet als een groot probleem gezien, omdat de farmaceutische industrie jaarlijks met nieuwe antibiotica op de markt kwam. Er is echter nog nooit een antibioticum ontwikkeld, waartegen bacteriēn geen resistentie ontwikkeld hebben.

Niet alleen is het aanbod van nieuwe antibiotica heden ten dage sterk verminderd, maar ook komt steeds meer gecombineerde resistentie, dus tegen verschillende soorten antibiotica, bij bacteriên voor: de zogenaamde multiresistente bacteriēn. Met name voor patiënten op de intensive care met een sterk verminderde weerstand en een hoge vatbaarheid voor infecties, is het van groot belang dat infecties zeker en snel bestreden kunnen worden. Bij deze patiënten is vaak geen tijd om uitgebreid en tijdrovend laboratorium onderzoek te doen en dient men in geval van een infectie te kunnen vertrouwen op een empirisch ingestelde therapie. Als deze therapie faalt bestaat er een gerede kans op overlijden van de patiënt. Het geschatte aantal ziekenhuis patiënten dat kwam te overlijden ten gevolge van infecties veroorzaakt door resistente bacteriën lag in de Verenigde Staten in 1992 op 13000 gevallen en dit aantal is sindsdien alleen nog maar toegenomen.

De opkomst van antibiotica resistentie is in drie stappen onder te verdelen. Allereerst moet een bacterie resistentie vergaren middels een mutatie of een resistentie gen overnemen van andere reeds resistente bacteriën uit zijn omgeving. Dit gebeurt spontaan en hierop is aanwezigheid van antibiotica in het milieu van de bacterie niet of nauwelijks van invloed. Of deze enkele resistente bacterie vervolgens weer verdwijnt of uitgroeit tot een resistente populatie hangt in grote mate af van selectiedruk veroorzaakt door antibiotica. Door het gebruik van antibiotica worden de bacteriën die voor die antibiotica gevoelig zijn gedood of in hun groei geremd, waardoor de 
bacteriën die resistent zijn voor dit antibioticum alle ruimte hebben om zich te vermenigvuldigen en de open gevallen plaatsen van de gedode gevoelige bacteriên op te vullen. Hoe meer antibiotica er gebruikt worden hoe meer selectiedruk dit te weeg zal brengen, en hoe makkelijker het is voor resistente bacteriën zich verder te ontwikkelen. Naast de selectiedruk van antibiotica, is de disseminatie van resistente bacteriën ook een erg belangrijke factor voor de verspreiding van antibiotica resistentie. Deze disseminatie kan door direct of indirect contact plaatsvinden tussen gastheren (mens of dier) en kan leiden tot overdracht en kolonisatie van resistente bacteriën of overdracht van resistentie genen aan de eigen bacterie flora van een nieuwe gastheer.

Antibiotica zijn niet selectief en doden niet alleen ziekteverwekkende bacteriën, maar iedere gevoelige bacterie die ermee in contact komt. Het grootschalige gebruik van antibiotica gedurende de laatste halve eeuw heeft daardoor niet alleen geleid tot antibiotica resistentie in pathogene bacteriën, maar ook tot grote aantallen resistente bacteriën in de darmflora van gezonde mensen en dieren, en het milieu. Antibiotica resistentie die wordt waargenomen bij pathogene bacteriën is enkel het topje van de resistentie ijsberg.

Er wordt veel onderzoek gedaan naar de resistentie ontwikkeling van pathogene bacteriën die infecties veroorzaken, aangezien dit natuurlijk een direct effect heeft op de effectiviteit van het medisch handelen en falen van therapie. Daarnaast kan het ook leiden tot een toename in de ernst van de ziekte, ziekteduur en mortaliteit, maar ook tot kostenverhoging van de gezondheidszorg. De darmflora als een omvangrijk reservoir van resistente bacteriën en genen, waar (potentieel) pathogene bacteriën naar believen uit kunnen putten wordt echter vaak onderschat. Resistentie waargenomen bij darmbacteriën kan zelfs fungeren als een waarschuwingssysteem voor te verwachten resistentie in pathogene bacteriën. Naast de uitwisseling van resistentie genen van bacteriën die in de darmflora leven of de darmflora enkel passeren, kunnen darmbacteriën zelf ook infecties veroorzaken. Escherichia coli, een voorname bewoner van de darmflora, is bijvoorbeeld een belangrijke veroorzaker van urineweginfecties.

Het ziekenhuis is een unieke omgeving voor de ontwikkeling van antibiotica resistente 
bacteriën. Dit komt met name door het hoge antibiotica gebruik (selectie) en de hoge dichtheid van patiënten en veelvuldige contacten met behandelaars en verpleging, die kunnen fungeren als transportmiddel (disseminatie). Daarnaast hebben ziekenhuis patiënten vaak een verminderde weerstand. Buiten het ziekenhuis vindt echter het grootste gedeelte van antibiotica consumptie plaats, zo'n $80 \%$ van het totaal gebruik door mensen. En dan hebben we het alleen nog maar over het humaan gebruik. Minstens zoveel antibiotica worden daarnaast nog gebruikt in de veehouderij en niet alleen voor behandeling en preventie van bacteriële infecties bij zieke dieren, maar ook als middel om slachtdieren sneller te laten groeien.

In dit proefschrift is er gekeken naar het voorkomen van resistentie bij darmbacteriën van gezonde mensen levend in de samenleving, aangezien de selectiedruk van antibiotica en risico factoren betrokken bij de ontwikkeling van antibiotica resistentie duidelijk verder reiken dan ziekenhuizen. In de verschillende hoofdstukken is er gekeken naar de relatie tussen het gebruik van antibiotica in de Nederlandse samenleving op regionaal niveau (Hoofdstuk 3 ) en in de tijd (Hoofdstuk 2), het effect van bevolkingsdichtheid (Hoofdstuk 4) en de rol van ziekenhuisopname (Hoofdstuk 5) op het voorkomen van antibiotica resistentie bij darmbacteriën. Daarnaast is in Hoofdstuk 6 gekeken of er genetische verwantschap bestaat tussen resistente en gevoelige darmbacteriën geïsoleerd uit mens en dier, m.a.w. zijn resistentie bacteriën in de darmflora van gezonde mensen deels afkomstig van dieren. Hieronder zullen de bevindingen uit de verschillende hoofdstukken kort besproken worden. In de hoofdstukken zijn de darmbacteriën Escherichia coli en enterococci gebruikt als indicator bacterie, aangezien zij twee voorname bewoners zijn van het darmkanaal. HOOFDSTUK 2. Van 1996 tot 1999 is het totale antibioticagebruik in de Nederlandse samenleving vrijwel gelijk gebleven; 3.542 en 3.598 DDD per 1000 inwoners per jaar. (DDD staat voor 'defined daily dosage.' Een kuur die wordt voorgeschreven door een huisarts bestaat gemiddeld uit 8,6 DDD.) Er vonden echter wel veranderingen plaats in de mate van gebruik van bepaalde soorten antibiotica door de introductie van nieuwe antibiotica. Zorgwekkend was de waargenomen toename van fluoroquinolones gebruik met $18 \%$ in combinatie met de waargenomen stijging in ciprofloxacin resistente $E$. coli van nul naar $2 \%$ in de darmflora van gezonde vrijwilligers. In eerste 
instantie lijkt deze toename minimaal, maar waar eerst geen resistentie werd waargenomen, is resistentie nu in opkomst. Hiernaast was er een significante afname in het voorkomen van vancomycine resistente enterokokken (VRE) in de darmflora van gezonde vrijwilligers. Vancomcyine is een analoog van avoparcine, dat werd gebruikt als groeibevorderaar in de veeteelt tot April 1997, en een reservoir van VRE veroorzaakt heeft bij slachtdieren. Antibiotica resistente bacterièn bij slachtdieren kunnen via de voedselketen in de darmflora van mensen terechtkomen (zie paragraaf Hoofdstuk 6). Het avoparcine verbod heeft dus niet alleen geleid tot een daling van het voorkomen van VRE in de darmflora van slachtdieren maar ook tot een significante daling in VRE bij de mens, terwijl het vancomycine gebruik bij de mens constant was gebleven.

HOOFDSTUK 3. Duidelijke regionale verschillen in het gebruik van antibiotica zijn waargenomen voor de steden Groningen, Maastricht en Rotterdam. Dit gold zowel voor het totale gebruik (11,19, 10,84 en 7,16 DDD per 1000 bewoners per dag) als verschillen in het gébruik van specifieke groepen antibiotica, zoals het hoger gebruik van macrolides in Rotterdam (1,77 DDD/1000 inwoners/dag). Wat betreft het voorkomen van antibiotica resistentie bij zowel $E$. coli als enterokokken, zijn er echter geen significante regionale verschillen gevonden in deze studie. Mogelijk kunnen de verschillen in antibiotica gebruik in de nabije toekomst wel leiden tot regionale verschillen in antibiotica resistentie.

HOOFDSTUK 4. Disseminatie van (resistente) bacteriën van patiënt naar patiënt direct of indirect via de verpleging wordt bevorderd door het feit dat in ziekenhuizen de patiënten dichtheid hoog is. Buiten het ziekenhuis zou een hoge bevolkingsdichtheid ook opgevat kunnen worden als een bevorderaar voor disseminatie van bacteriën. In Hoofdstuk 4, werd daardoor antibiotica gebruik uitgedrukt in DDD per vierkante kilometer per dag naast DDD per 1000 inwoners per dag, voor de steden Groningen (Nederland), Athene (Griekenland) en St. Johns (Canada). Er werd een veel sterkere correlatie gevonden tussen het voorkomen van antibiotica resistente bacteriën in de darmflora van gezonde vrijwilligers en het gebruik van antibiotica per vierkante kilometer dan per 1000 inwoners. Deze resultaten geven aan dat ook bevolkingsdichtheid een belangrijke factor is en medebepalend voor 
de mate van antibiotica resistentie in een populatie. In de resistentie epidemiologie dient dan ook hieraan aandacht geschonken te worden.

HOOFDSTUK 5. Zoals vele studies hebben aangetoond is het ziekenhuis een unieke broedplaats voor resistente pathogene bacteriën. Over het effect van ziekenhuisopname op de darmflora van patiënten is echter nog niet veel bekend. In Hoofdstuk 5 wordt een studie beschreven waarbij het voorkomen van resistente $E$.coli in de darmflora van patiënten voor ziekenhuisopname, bij ontslag en 1 en 6 maanden na ontslag bepaald is. De studiepopulatie bestond uit patiënten die werden opgenomen op de chirurgische afdelingen van de Academische ziekenhuizen in Groningen, Maastricht en Rotterdam. In deze studie zijn er geen significante verschillen gevonden op de tijdstippen waar het voorkomen van antibiotica resistente $E$. coli werd bepaald. Er waren ook geen duidelijke verschillen in het voorkomen van antibiotica resistentie tussen de verschillende ziekenhuispopulaties, ondanks de duidelijke verschillen in populatie karakteristieken. Op chirurgische afdelingen is het antibiotica gebruik laag vergeleken met Intensive Care Units en hematologie afdelingen. Hier is dus de selectiedruk veel hoger dan op chirurgische afdelingen. Ook is de ligduur op deze afdelingen hoger en is de weerstand van de patiënten veel vaker ernstig verminderd, wat de disseminatie en kolonisatie van antibiotica resistente bacteriën in de darmflora bevordert, en zou kunnen leiden tot een duidelijker effect op het voorkomen van antibiotica resistentie in de darmflora. Nader onderzoek naar de invloed ziekenhuisopname op de antibiotica resistentie in de darmflora bij dit type patiënten en de interactie van verschillende resistentie reservoirs, lijkt dan ook dringend gewenst.

HOOFDSTUK 6. Een belangrijk reservoir van antibiotica gebruik in de samenleving is het grootschalig gebruik van antibiotica als groeibevorderaar en voor infectie preventie in de veeteelt. Zoals al eerder besproken heeft het gebruik van avoparcine zeer waarschijnlijk geleid tot het voorkomen van vancomycine resistente enterokokken (VRE) in de darmflora van gezonde individuen. Genetisch verwante VRE stammen zijn regelmatig gevonden bij varkens, vleesproducten, gezonde individuen, en zelfs ziekenhuispatiënten. Deze bevindingen suggereren een transmissie route tussen dier en mens, wat betekent dat resistente bacteriën afkomstig van dieren kunnen bijdragen aan de kolonisatie en infecties bij de mens. In hoofdstuk 6 hebben we niet alleen gekeken 
naar de genetische verwantschap van vancomycine resistente maar ook van vancomycine gevoelige enterokokken (VSE) afkomstig van verschillende bronnen. Uit de studie bleek dat VRE afkomstig van gezonde mensen en varkens sterk verwant zijn, terwijl VRE afkomstig van kippen een duidelijk aparte groep vormden samen met de VSE afkomstig van kippen. Daarentegen, waren de VSE afkomstig van varkens en gezonde mensen veel heterogener dan VRE, en was er geen duidelijke clustering van deze VSE stammen. Deze bevindingen suggereren dat varkens een belangrijkere bron zijn van VRE voor mensen, dan kippen. Waarom bacteriën afkomstig van kippen in tegenstelling tot varkens minder goed lijken te overleven in de darmflora van de mens blijft een vraag. Onderzoek naar specifieke karakteristieken zoals virulentie factoren, kolonisatie en persistentie mogelijkheden van bacteriën afkomstig uit verschillende menselijke en dierlijke bronnen is nodig om de invloed van deze factoren op de overdracht en het overleven van resistente bacteriën in de darmflora van de mens te bepalen.

De verscheidenheid in factoren van invloed op de ontwikkeling en verspreiding van antibiotica resistentie kan worden samengevat in 4 onderdelen: de bacterie, de gastheer, antibiotica gebruik en de omgeving. Alhoewel de relatie tussen antibiotica gebruik en antibiotica resistentie algemeen is geaccepteerd, blijft de kwantitatieve correlatie tussen beide achterwege. Dit benadrukt des te meer de complexheid van het antibiotica resistentie fenomeen, en benadrukt het belang verder te kijken dan antibiotica gebruik in het gevecht tegen antibiotica resistentie. Een duidelijk voorbeeld hiervan staat beschreven in Hoofdstuk 4, waar antibiotica gebruik alleen geen duidelijke correlatie vertoonde met het voorkomen van resistentie terwijl dit wel het geval bleek wanneer bevolkingsdichtheid bij de vergelijking betrokken werd.

Van groot belang voor het behoud van de lage mate van antibiotica resistentie en gebruik in Nederland, is het monitoren van antibiotica resistentie in de darmflora van gezonde vrijwilligers in de samenleving zowel op regionaal niveau als in de tijd. Naast resistentie gevonden in pathogene bacteriën zouden dergelijke epidemiologische data de basis moeten vormen voor het opzetten en controleren van antibiotica richtlijnen en 
fungeren als een waarschuwingssysteem voor resistentie die op korte termijn verwacht kan worden in pathogene bacteriën. Behalve het feit dat de grootste hoeveelheid antibiotica door mensen buiten het ziekenhuis gebruikt worden, vindt in deze open populatie ook een interactie plaats van verschillende resistentie reservoirs zoals ziekenhuizen, kinderdagverblijven, verpleeghuizen en intensieve veehouderij. Daarom dient onderzoek naar antibiotica resistentie in de darmflora van gezonde vrijwilligers een sleutelpositie in de resistentie epidemiologie in te nemen en is het niet alleen een erg belangrijke bron voor surveillance, maar ook een makkelijk toegankelijke. 


\section{Dankwoord}


De voorstelling dat dit proefschrift werkelijkheid zou worden leek vaak onwerkelijk. Toch ligt het hier voor $\mathrm{u}$, maar niet zonder hulp van velen die ik nu zal pogen waardig te bedanken.

Allereerst mijn copromotoren, Ellen en Ton. Ik kan mij nog goed herinneren dat ik beteuterd bij Ellen op de kamer zat, omdat mijn geplande $2^{\text {de }}$ stage naar Canada op het laatste moment niet doorging. Misschien is het nu niet het juiste moment, maar ik heb hier ook iemand nodig om met het EMAR (Extramuraal Monitoren van Antibiotica Resistentie) project van start te gaan, was wat Ellen mij zei. Deze kans kon ik niet laten schieten, aangezien mijn interesse voor het fenomeen antibiotica resistentie al eerder was gewekt. Hier ben ik Ellen dan ook erg dankbaar voor. Eenmaal van start als OlO bij Medische Microbiologie leerde ik Ton al snel kennen. Zo verschillend als Ton en Ellen zijn, zo goed vulden zij elkaar aan in het mij begeleiden. In de laatste fase van het vervaardigen van dit proefschrift was ik elke keer weer verbaasd over de snelheid waarmee Ton mijn teksten van commentaar voorzag, zodat ik op mijn beurt ook weer aan de slag kon. Ellen en Ton bedankt voor alles!

Maar waar was ik geweest zonder de gezelligheid op het lab, de radio aan en zingen en werken maar. Christel en Nancy als rotsen in de branding, hun kennis en ervaring zorgde ervoor dat alles in goede banen geleid werd. Elke, Gilles, Karin, Kim, Sita, Lucy, Monique, Dominique, Melanie (en iedereen die ik vergeten ben) bedankt voor het plezierig werken, en jullie mogen de radio houden. Mijn extra dank gaat uit naar Lucy en Sita, die nog een enorme hoeveelheid werk verstouwd hebben om de ziekenhuis studie af te kunnen ronden, terwijl ik al op het RIVM zat. Soms was het niet allemaal even duidelijk, mijn excuses hiervoor, maar jullie hebben het voor elkaar gekregen! Op de kamer was vaak wisseling van de wacht, maar Daisy was er altijd, en ik kon haar ook altijd storen met vragen of een goed gesprek. Na een gesprekje met Daisy leek alles altijd een stuk makkelijker.

Het EMAR project, waar dit proefschrift uit gerealiseerd is, werd uitgevoerd in samenwerking met de afdeling Medische Microbiologie van het academisch 
ziekenhuis Groningen en Rotterdam, mijn dank dan ook aan John Degener (azG), Hubert Endtz en Margreet Filius (azR).

De coauteurs in dit proefschrift wil ik natuurlijk ook hartelijk bedanken voor hun expertise. Speciaal wil ik hierbij Rob Willems bedanken die naast al zijn kennis, ook zijn lab beschikbaar heeft gesteld. Ook wil ik Margreet Filius extra bedanken voor haar kritische blik en gezellige besprekingen, die niet alleen over werk gingen, maar ook over bijvoorbeeld huizen kopen. Inmiddels zijn we allebei trotse huiseigenaars.

Verder, niet te vergeten, mijn paranimfen Margreet en Lucy, bedankt dat jullie mij bij willen staan!

Verder wil ik bedanken; Auke voor de prachtige kaft, Patricia en de rest van het Secretariaat Medische Microbiologie voor hun behulpzaamheid, Linda Wildeboer voor de werving in Groningen, mijn CIE collega's op het RIVM voor hun open ontvangst op de afdeling, natuurlijk het EARSS team, waar ik dankbaar deel van uitmaak, en alle vrijwilligers die hun poepje hebben ingestuurd!

Mijn dank gaat natuurlijk ook uit naar mijn ouders die mij de kans hebben gegeven om te gaan studeren en samen met mijn zus Femke erg betrokken zijn geweest bij het wel en wee van dit proefschrift. Daarbij ben ik ook erg blij dat mijn vrienden het met me hebben uitgehouden in deze toch wat hectische tijd en dat het maar een mooi feestje mag worden 12 december. Erik Jan, jij was mijn rustpunt. Wanneer het soms wat veel werd allemaal, was jij daar altijd die de boel heerlijk relativeerde en de bomen weer zichtbaar maakte.

Nienke 


\section{CURRICULUM VITAE}

Nienke Bruinsma werd op 26 augustus 1976 geboren te Son. Van 1989 tot 1994 volgde zij haar middelbare schoolopleiding aan het Lorentz-Lyceum te Eindhoven. In 1994 begon zij met haar studie Gezondheidswetenschappen aan de Universiteit Maastricht, waar zij in januari 1999 haar Doctoraal Diploma behaalde. Tijdens haar stage deed zij onder supervisie van Dr. E. E. Stobberingh een onderzoek naar shuntinfecties bij kinderen tot 6 jaar, behandeld voor hydrocephalus, in het academisch ziekenhuis Maastricht (azM). Van januari 1999 tot oktober 2001 was zij werkzaam als onderzoeker in opleiding bij de afdeling Medische Microbiologie van het azM. Hier heeft zij zich ingezet voor het EMAR project, Extramuraal Monitoren van Antibiotica Resistentie. Vanaf oktober 2001 is zij werkzaam bij het Rijksinstituut voor Volksgezondheid en Milieu (RIVM) waar zij epidemioloog is bij het European Antimicrobial Resistance Surveillance System (EARSS). 
